University of Louisville

ThinkIR: The University of Louisville's Institutional Repository

Electronic Theses and Dissertations

$12-2018$

\title{
The unequal city: the mass criminalization of the urban poor.
}

Elizabeth Michele Jones

University of Louisville

Follow this and additional works at: https://ir.library.louisville.edu/etd

Part of the Geography Commons, Political Science Commons, Race and Ethnicity Commons, and the Urban Studies and Planning Commons

\section{Recommended Citation}

Jones, Elizabeth Michele, "The unequal city: the mass criminalization of the urban poor." (2018). Electronic Theses and Dissertations. Paper 3077.

https://doi.org/10.18297/etd/3077

This Doctoral Dissertation is brought to you for free and open access by ThinkIR: The University of Louisville's Institutional Repository. It has been accepted for inclusion in Electronic Theses and Dissertations by an authorized administrator of ThinkIR: The University of Louisville's Institutional Repository. This title appears here courtesy of the author, who has retained all other copyrights. For more information, please contact thinkir@louisville.edu. 


\title{
THE UNEQUAL CITY: THE MASS CRIMINALIZATION OF THE URBAN POOR
}

\author{
By \\ Elizabeth Michele Jones \\ B.A., University of Louisville, 2004 \\ M.A., University of Louisville, 2006 \\ J.D., Georgetown Law Center, 2009
}

\begin{abstract}
A Dissertation
Submitted to the Faculty of the

College of Arts and Sciences of the University of Louisville in Partial Fulfillment of the Requirements

for the Degree of
\end{abstract}

Doctor of Philosophy

in Urban and Public Affairs

Department of Urban and Public Affairs

University of Louisville

Louisville, Kentucky

December 2018 
Copyright 2018 by Elizabeth Michele Jones

All rights reserved 



\title{
THE UNEQUAL CITY: THE MASS CRIMINALIZATION OF THE URBAN POOR
}

\author{
By \\ Elizabeth Michele Jones \\ B.A., University of Louisville, 2004 \\ M.A., University of Louisville, 2006 \\ J.D., Georgetown University Law Center, 2009 \\ A Dissertation Approved on
}

November 1, 2018

By the following Dissertation Committee

$\overline{\text { Dissertation Director Dr. David Imbroscio }}$

Committee Member Dr. David Simpson

Committee Member Dr. Margath Walker

Committee Member Dr. Timothy Weaver 


\section{DEDICATION}

This dissertation is dedicated to my mother

Mary C. Jones

for her unconditional love and support. 


\section{ACKNOWLEDGEMENTS}

I would like to thank Dr. Timothy Paul Ryan Weaver, for his critical feedback, guidance, and patience during the course of completing this work. Dr. Weaver was most instrumental in seeing this dissertation come to fruition. I would also like to thank the PhD program director and committee member Dr. David Imbroscio, for his direction during this process as well and for helping me see this research through to the end. Thank you to my other committee members, Dr. David Simpson and Dr. Margath Walker, for their constructive criticism and for serving on my committee. Lastly, I would like to thank the Louisville residents who agreed to be interviewed for this study. I greatly appreciated their candor and transparency and their time. Also, I am indebted to the countless people who were incredibly supportive and facilitated the interviewing process from the Baxter Community Center, The Table, Portland Neighborhood House, and the many volunteers who helped canvass and recruit. 


\title{
ABSTRACT \\ THE UNEQUAL CITY: THE MASS CRIMINALIZATION OF THE URBAN POOR
}

\author{
Elizabeth M. Jones
}

November 1, 2018

Exploring and understanding the widespread use of arrests and incarceration in urban neighborhoods of concentrated poverty is the subject of this dissertation. The research addresses gaps in theoretical debates about the causes of mass criminalization that position the phenomenon as the result of either neoliberalism or racism. In addition, the dissertation explores the impact of mass criminalization on urban citizenship. Urban citizenship is a theoretical frame that considers the substance of the economic, social, political, and mobility dimensions of city life. The research methodology is a case study of two impoverished neighborhoods in the city of Louisville, Kentucky that incorporates both qualitative and quantitative data. The researcher systematically analyzed interviews with 72 residents in the neighborhoods of Russell and Portland using the frames of urban citizenship to answer how mass criminalization impacts the lives of urban residents.

The findings of the dissertation show ubiquitous carceral state interventions into the poor neighborhoods in the study create spaces of attenuated citizenship. The interviews show how carceral state interventions shape the lives of residents along social, political, and economic lines and in their ability to move freely throughout their community and access public space without state interference. The research also illuminates how urban governance for the poor often occurs through processes of surveillance and punishment, despite government interventions being antithetical to the philosophy of neoliberalism. Finally, a major theoretical contribution of the dissertation is the way it engages the race and class debate surrounding the carceral state by interviewing individuals from a predominately black and a predominately white 
neighborhood. The findings from the interviews show that class strongly influences the impact of the carceral state in a way that crosses racial lines, making a consideration of both integral to a full understanding of mass criminalization in urban neighborhoods. 


\section{TABLE OF CONTENTS}

CHAPTER ONE: THE ENIGMA OF MASS CRIMINALIZATION \& THE CARCERAL STATE EXPLOSION

1

CHAPTER TWO: RACE, NEOLIBERALISM, \& THE CARCERAL STATE............13

CHAPTER THREE: EXPLORING IMPACTS, CITIZENSHIP, \& THE CARCERAL

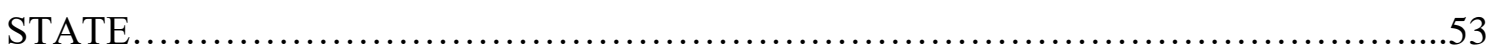

CHAPTER FOUR: THE CASE STUDY \& METHODOLOGY $\ldots \ldots \ldots \ldots \ldots \ldots \ldots \ldots \ldots . \ldots$

CHAPTER FIVE: HYPERSEGREGATED AND HYPERPOLICED ................... 107

CHAPTER SIX: COMPLICATING RACE \& THE CARCERAL STATE.................148

CHAPTER SEVEN: CONCLUSIONS........................................... 170

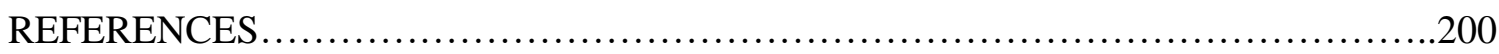

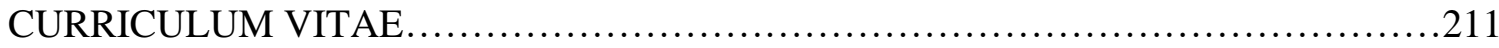




\title{
CHAPTER ONE: THE ENIGMA OF MASS CRIMINALIZATION \& THE CARCERAL STATE EXPLOSION
}

\author{
"The sprawling carceral state, the random detention of black people, the torture of suspects are the product \\ of democratic will." - Ta-Nehisi Coates, Between the World \& Me
}

Over the course of fifty years, the American carceral state has become the most expansive in the globe. No other industrialized country incarcerates its citizenry at a rate even remotely approaching that of the United States. Home to 5\% of the global population, the U.S. houses 25\% of the world's prisoners (Justice Policy Institute, 2000). A South African legal scholar once remarked to me, "You Americans do love your prisons," a statement not without empirical support. In 2012, "there [were] more people under 'correctional supervision' in America- more than six million- than were in the Gulag Archipelago under Stalin at its height" (Gopnik, 2012). According to Bruce Western (2006), "Between 1970 and 2003, state and federal prisons grew sevenfold to house 1.4 million convicted felons serving at least one year behind bars" (p.3).

The reach of the carceral state and mass incarceration are not uniformly dispersed across the American landscape. In fact, the rate of prison incarceration nationally has declined $14 \%$ since reaching its height in 2007. Kentucky, however, stands in contrast to national trends as prison populations in the state continue to rise. Between 2016 and 2017 Kentucky had the third highest rate of prison incarceration growth in the nation with a $3.7 \%$ increase over the course of the year (Vera Institute, 2018). The charts included 
below created by the Vera Institute using national data, show that jail incarceration rates in both the state and in Jefferson, County remain higher than the national average. In Jefferson County, Kentucky, black people are incarcerated in jail at a rate higher than that of their white counterparts. The unequal dispersion of mass incarceration points to variations in the unfolding of the political economy in space and highlights the need for thoughtfulness surrounding state and local carceral state institutions.

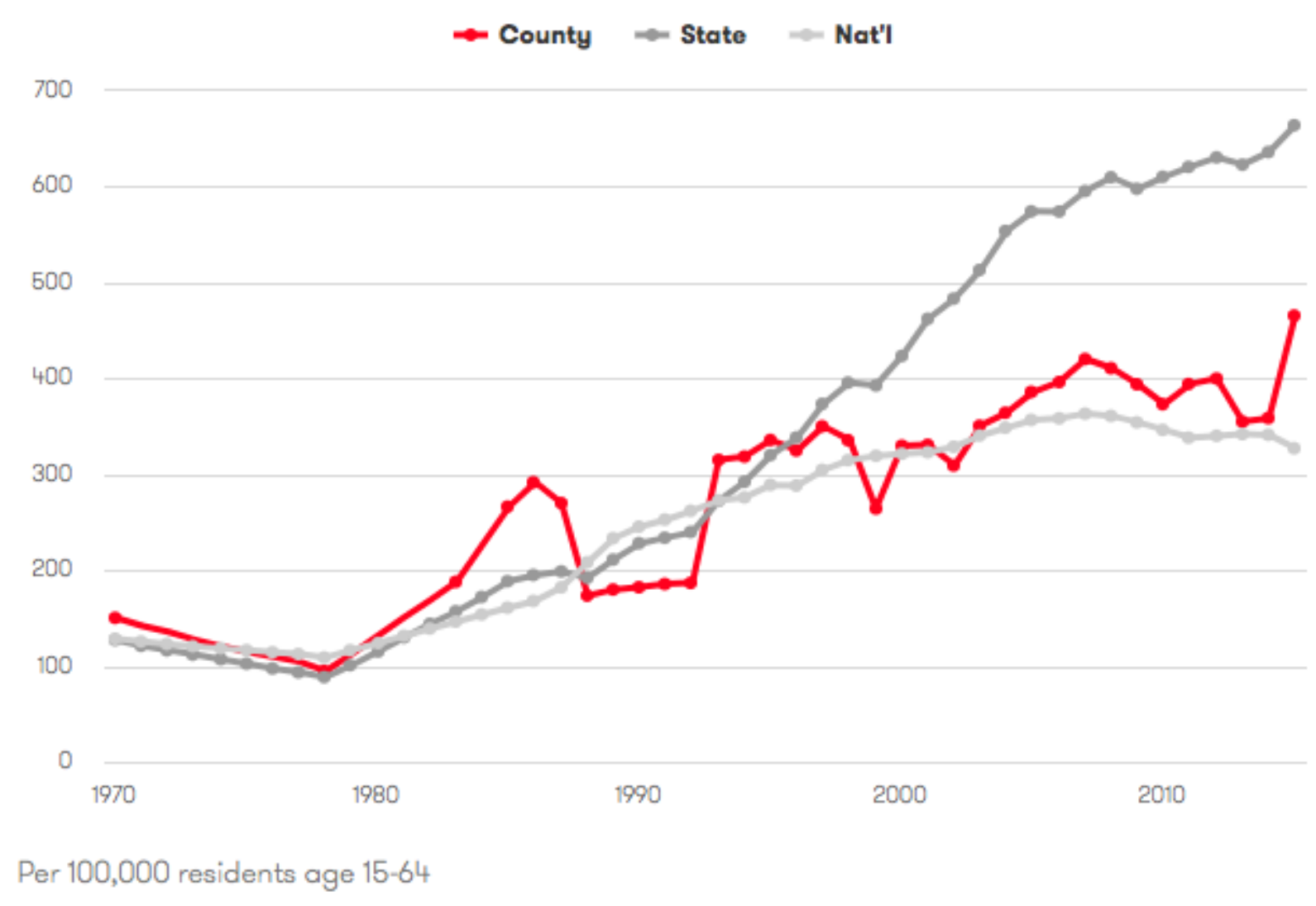

Figure 1. Vera Institute Comparison of County, State, and National Jail Incarceration Rates. Jefferson County, Kentucky; Kentucky; and the United States. 2018. 


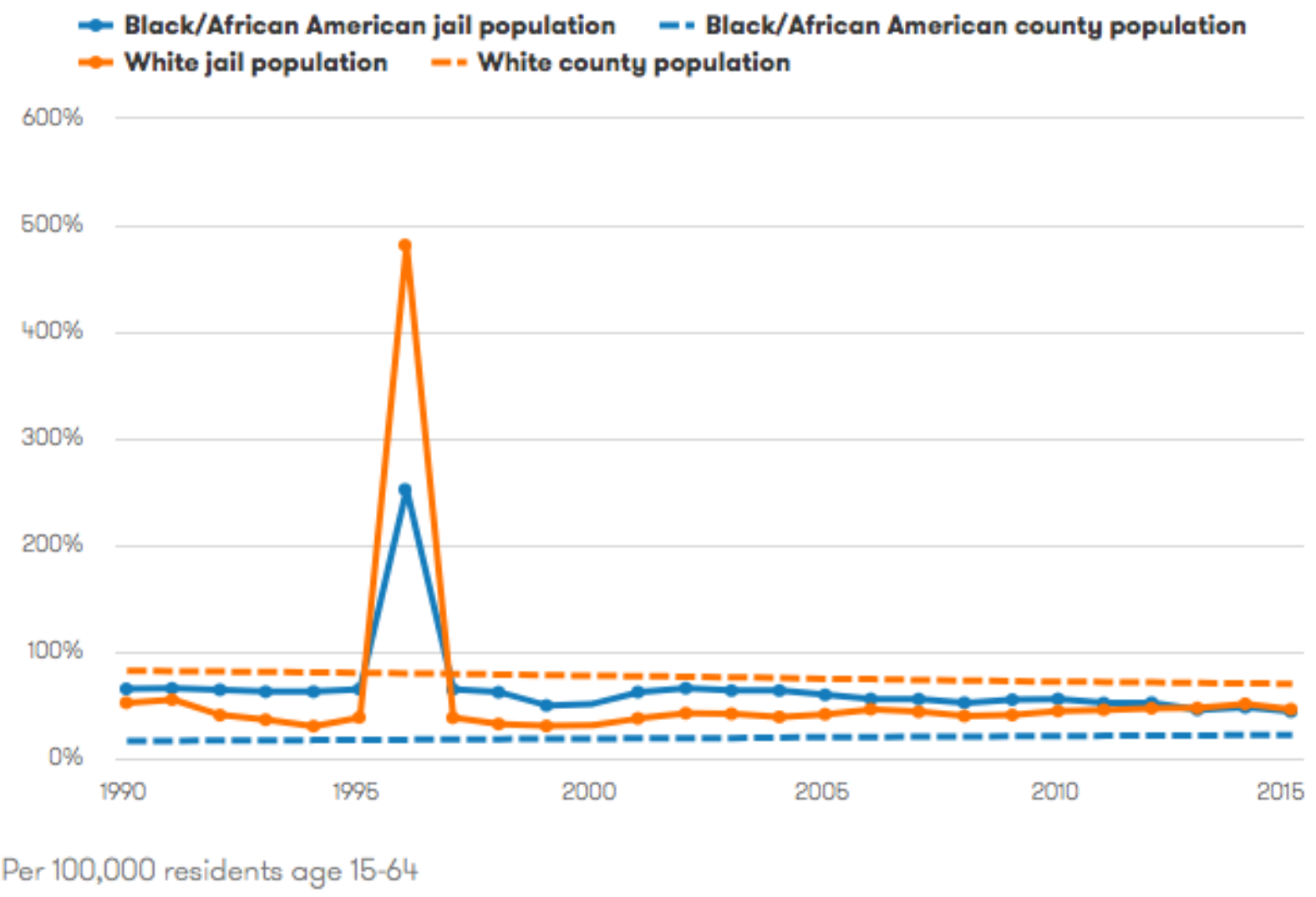

Figure 2. Vera Institute Comparison of Jail Incarceration Rate vs. County Population by race in Jefferson County, Kentucky. 2018. 


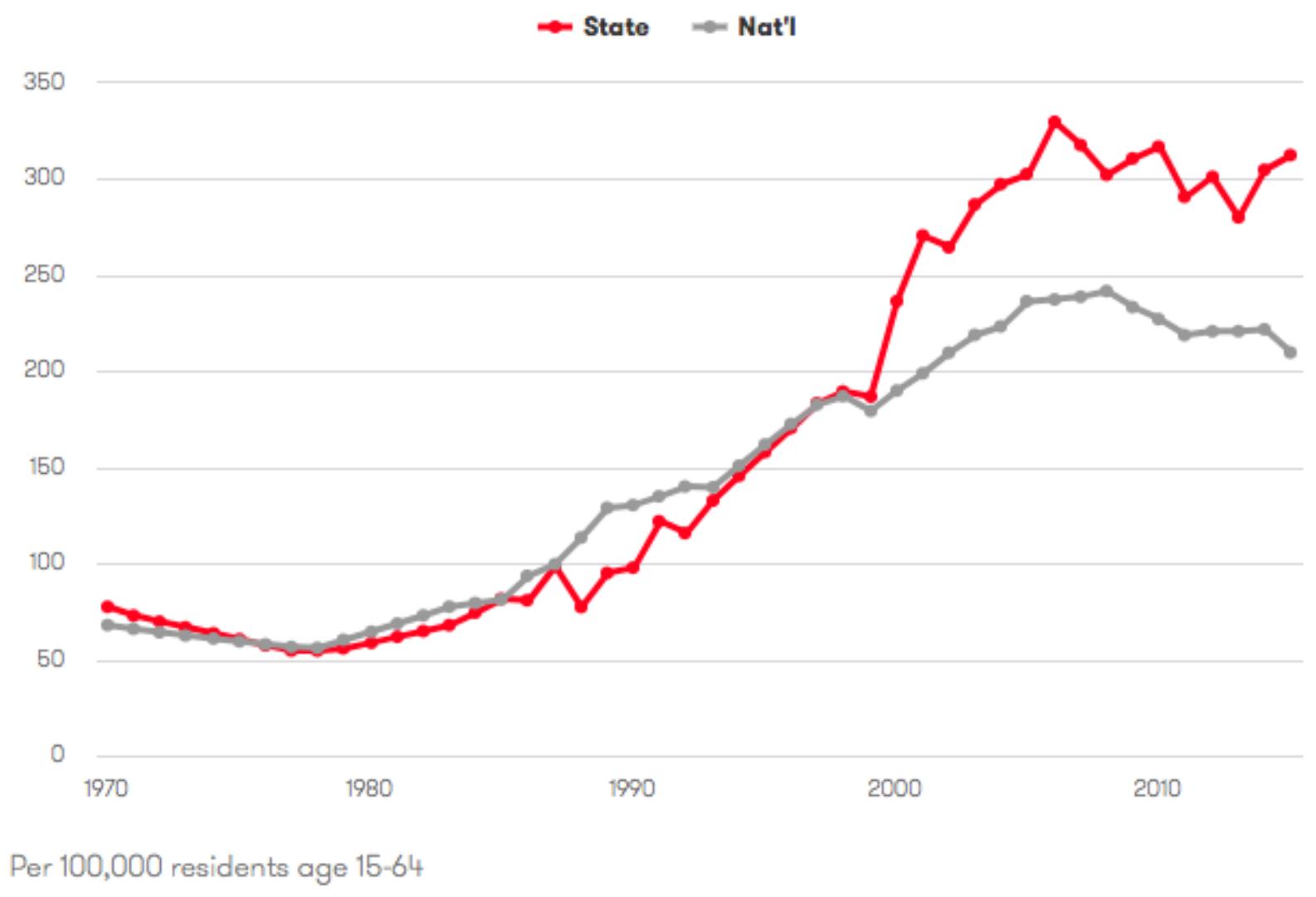

Figure 3. Vera Institute Comparison of Pretrial Incarceration Rate State vs. National Average. 2018.

Due to the sheer size and scope of the extensive carceral state and its unequal concentration in space, particularly where poor people of color reside, one must ask what are the impacts of these persistent, punitive state interventions on the communities in which they are concentrated? And further, what can we learn about the political economy and race when so many residents from a particular subsection of the population experience incarceration? Critical to answering these questions is first moving beyond a consideration of felony convictions and prison stays, to consider the broader phenomena of mass criminalization and the various capacities of the state to surveil and punish. Jack Chin (2012) notes the reach of the carceral state, "includes the more than six million in control of the criminal justice system who are not in custody plus the tens of millions 
who have a record but are not in prison or jail" (p. 1805). The term mass criminalization captures the much wider reach of the carceral state and encompasses low-levels of contact such as stop and frisk, arrests with short-term jail stays, and penalties for lowlevel offenses such as fines. Broadening the scope illuminates a broader variety of state punishments. In this vein, the term "carceral state," in lieu of simply the criminal justice system, refers to the state's exercise of its punishment and surveillance powers in a variety of forms. The carceral state reaches into neighborhoods and homes and overlaps with other parts of the state such as social welfare.

Gottschalk (2015) characterizes the reach of the carceral state as "breathtaking," citing the state supervision of one in twenty-three adults as proof. She writes a wide swath of the populace is "under some form of state control, including jail, prison, probation, parole, community sanctions, drug courts, immigrant detention, and other forms of government supervision" (p. 1). These carceral state interactions have ripple impacts on families and entire communities where they are concentrated. As Western (2006) noted, "The children and wives of former prisoners are also drawn into the orbit of the penal system, through the disruption of family life and the contagious stigma of incarceration" (p. 193).

Since the 1970s, technological and legal changes have facilitated the heightened incarceration and surveillance of citizens. Stop and frisk policing, electronic monitoring, and a host of other supervisory practices are now routine, normal functions of the carceral state. The logic of punishment and retribution drives criminal justice institutions, and democratically elected officials often translate race-baiting, law and order political platforms into harsh legislative enactments. In a country that holds its democratic 
institutions and ideals in such high esteem, the carceral state stands as a profound anathema. A great deal of literature has been devoted to measuring and comprehending the fallout of the massive American carceral state in recent years (Alexander, 2010; Burch, 2013; Butler, 2017; Davis, 2017; Gottschalk, 2015). Most often discussed as mass incarceration, carceral state literature can be broadly divided into two primary camps: one reviewing its causes and another postulating its effects, although the two intersect at certain points.

Sociologists have measured the multiple effects of prison incarceration on social life including families, work, wages, and marriage (Pager, 2007; Western, 2007; Allard, 2012; Wildeman, 2009). Mass incarceration has rendered large numbers of low-educated young men invisible in wages and employment statistics due to their incarceration. According to Western (2006), "accounting for prison and jail inmates among the jobless, employment among less-educated black men declined during the economic expansion of the 1990s" (p. 190). Not only does mass incarceration disguise economic trends, it maintains a "tight grip" on the low-wage labor market and exacerbates the disadvantage of returning felons (Western, 2006, p. 190). Wildeman (2009) illustrated the ripple of effects of mass incarceration through his research on the children of incarcerated parents finding that, "parental imprisonment has emerged as an important childhood risk, especially for black children. By 1990, the risk of parental imprisonment was greater than $25 \%$ for black children; for white children, the risk was 4\%" (p. 266). In a study by Wildeman and Wakefield (2011), the researchers determined the incarceration of a father increases aggression and mental health and behavioral problems in children. 
In addition to the sociological implications of the carceral state, political scientists, such as Gottschalk (2015) and Lerman and Weaver (2014) have also begun to grapple with the political effects of the carceral state, and its implications for citizenship and democracy. Lerman and Weaver (2014) developed the concept of custodial citizenship, a key frame used in this study. "Custodial citizens are constituted not as participatory members of the democratic polity, but as disciplined subjects of the carceral state" (p.111). Gleaned through interviews, these scholars carefully describe the "lifeworld" of custodial citizens as distinct, writing, "For a substantial number of those we interviewed, encounters with criminal justice authorities were their most proximate (and memorable) experience of government... custodial citizens come to view the political system at least in part, if not primarily, about control, authority, and dominance" (p. 15). The topic of custodial citizenship is undergirded by the question of who is a custodial citizen. And further, how is their citizenship shaped by direct or indirect carceral state experiences?

\section{Introduction to the Study}

The key questions posed in this research are designed to understand how city residents experience citizenship when carceral state interactions are a part of everyday life in their community. It asks, how does neighborhood-wide mass criminalization shape the resident perceptions of local government in the community where they reside? What can residents in high-incarceration neighborhoods in constant contact with the carceral state teach us about democracy, urban governance, and citizenship? How do a 
combination of race, class, gender, and space nuance and inform substantive citizenship experiences in the city?

This study investigates the role of the carceral state in influencing how residents in two neighborhoods of concentrated poverty experience local government and substantive citizenship. It examines how the disproportionate presence of the carceral state in poor neighborhoods influences substantive citizenship experiences along lines of race and class by interviewing residents in a predominately black neighborhood and a predominately white neighborhood. Considering both race and class opens the door to contributing to key debates in the literature tied to the hyperpunitive turn of neoliberalism and to comprehending the vast racially-disparate impacts of the carceral state. Often, neoliberalism and racism are discussed separately, as will be outlined in the next chapter. I attempt to place these two literatures in conversation with each other to make broader claims about the interconnection between race, class, and the hierarchical structure of the political economy.

This research study is also urban in focus, and the city space is a key frame for the investigation. While much scholarship thinks of mass criminalization nationally or even state-wide, considering the local and urban neighborhoods is another way I seek to contribute to the literature. The project asks, what do American democracy and urban governance mean for residents besieged by the carceral state? And, how does frequent contact with the carceral state impact substantive citizenship in the city? The four research questions I pose to achieve my research objectives are: 
1.) How do residents in neighborhoods experiencing heightened contact with the carceral state describe the neighborhood where they live and its relationship to the city's social life and government?

2.) How does living in a neighborhood characterized by racial isolation and concentrated poverty impact the type and quality of contact with the carceral state?

3.) How does contact with the carceral state influence and shape the everyday lived experiences of citizenship in the city?

4.) Are there variations in the articulation of these everyday lived experiences of citizenship in the city resulting from interactions with the carceral state along lines of race, class, and gender?

In the next chapter, I will discuss the key debates in the literature related to neoliberalism and race and provide a more nuanced account of mass criminalization that unpacks the merger between race and class in the American political economy. The second chapter entitled "Race, Neoliberalism, and the Carceral State" describes these two camps and how they articulate the carceral state explosion before providing a critique of the mutually exclusive approach.

Chapter Three called "Exploring Impacts, Citizenship \& the Carceral State" begins with an account of why analyzing the urban space is uniquely important to 
supplementing our understanding of the carceral state. In the third chapter I lay out an analytical framework for grasping the neighborhood-wide impact of the carceral state that I have named "citizenship in the city." Pulling from a variety of literatures on citizenship from political scientists and urban scholars, I detail the four-part concept used to organize the research findings. The methodology for undertaking this investigation and the outline of my research design are detailed in Chapter Four. The chapter provides context to the case study through describing the city and neighborhoods of study and explains the data collection process, data analysis, and barriers and limitations to the project.

After the theoretical and methodological chapters, the enquiry turns to discussing the original research data collected by the investigator. Chapter Five details interviews with forty residents of a predominately black housing project named Beecher Terrace, and three community members living on its outskirts in Russell. Entitled, "Hypersegregated and Hyperpoliced," the chapter discusses themes emerging from the data on neighborhood life and local government and describes substantive citizenship using the concept of citizenship in the city. Chapter Six concerns itself with the neighborhood of Portland, a community of concentrated poverty that is predominately white demographically. While all of the Beecher and Russell interviewees identified as black, the Portland interviewees were racially mixed, lending itself to providing more nuance to the conversation on race and the carceral state. The dissertation concludes with Chapter 7 that outlines final thoughts on the research questions and pinpoints the ways the findings add to existing literature.

The interviews with residents that form the crux of the data for this dissertation led me to three major findings. First, that urban space and, more specifically neighborhoods, 
define the contours of substantive citizenship and contributes to a custodial status. In fact, "custodial" may be an insufficient term to grasp the rendering of suspiciousness, widespread surveillance, and hyperpunitiveness of the local carceral state toward the neighborhoods of study. Hypersegregated neighborhoods experience heightened carceral state presence, and its concentration in space leads to ripple impacts among all community members, even those without direct carceral state contact themselves. The focus of the literature on prison re-entry and those directly experiencing mass criminalization misses how the carceral state fundamentally reshapes citizenship in entire communities. We have to ask if residents in communities like that included in the study live in an equal, democratic society.

Not only does the pervasiveness of the carceral state in space reconfigure citizenship but, it acts to maintain a structural hierarchy along lines of race and class. The second major finding of this study illuminates the ways local government institutions, including police departments, are impacted by neoliberal ideology. The concepts of individual responsibility and laissez-faire market principles of neoliberalism influence the policies of local institutions and the urban governance of poor communities. Citizenship takes on a new meaning in the neoliberal city through primarily defining the citizen as a rational actor in the free-market, not as a community member with social and emotional ties to their neighborhoods. The resident interviews show how those who live in poverty most often encounter the sate through is punishment and surveillance mechanisms. It also shows the limitations residents have in their "rights to the city." Community members have inadequate input in whether they can stay or go in their place of residence as the 
result of revitalization and are unable to influence the local institutions that govern their lives like police and social welfare.

Lastly, the research I present here complicates the conversation around race and the criminal justice system, by intentionally thinking about the nuances of both race and class in relationship to each other. Two views of mass criminalization predominate the literature, one focused on the neoliberal political economy and the other on racial animus. These conversations most commonly proceed down parallel lanes with minimal consideration of the intersection between the two. This project attempts to illuminate how race and class are inseparable in analyzing both the causes and effects of the carceral state by providing historical context to the phenomena of mass incarceration and the race and class dynamics in existence before the explosion beginning in the 70s. 


\title{
CHAPTER TWO: RACE, NEOLIBERALISM \& THE CARCERAL STATE
}

\begin{abstract}
"Much of the work on neoliberalism is not attentive enough to the roles of race, gender, and ethnicity in shaping economic policies. Likewise, much of the literature on race is inattentive to how the sinews of the political economy shape policy and politics" - Marie Gottschalk, Caught
\end{abstract}

The literature on mass criminalization is most often framed as the result of racism or neoliberalism, with very little overlap between the two academic conversations.

Whether race or the neoliberal economy fuels the massive expansion of the carceral state is critical to unpacking the causes of mass criminalization. On the one hand, a subset of academics contend mass incarceration is a phenomenon generated by racism, what I will call the "racial motivation" camp. Scholars such as Michelle Alexander (2010) and Paul Butler (2017) argue the carceral state is driven by colorblind racism and intentionally targets African-Americans. These scholars generate compelling arguments on race and the carceral state but fail to deeply excavate the connection between race and class to unpack the economic drivers of carceral state expansion.

Another contingent of scholars, including Wacquant (2009), point to neoliberal developments in the political economy as the cause of the expansive carceral state. This approach argues neoliberal state restructuring has effectively scaled back the state's social welfare arm while expanding its punitive and surveillance capacities. Neoliberal explanations for mass incarceration too often pay scant attention to the role of colorblind racism as part of the neoliberalization process. Neoliberalism is as much an idea about laissez-faire economics as a form of governance and the individual responsibility of 
citizens as it is a political and economic practice impacting and reshaping democracy. In the American political economy race is a mainstay and plays an instrumental role ideologically and as a structuring force in society, all while it vacillates and changes content overtime.

Both lines of argumentation are persuasive and supported by compelling evidence but an either/or approach to understanding the carceral state misses the uniquely American intersection between race and class. It neglects to understand the malleable nature of race in relationship to the fluctuating political economy, and the persistence of hierarchical racial inequalities that are ever-present in social, institutional, and economic outcomes. Why is it that in American society when one system of racialized social control is dismantled, another rises in its wake? And further, why do racial disparities in incarceration, education, and wealth continue to persist?

Viewing race and the political economy as mutually exclusive instead of interconnected creates analytical gaps in understanding the answers to the questions posed above. A focus on the highly-disproportionate incarceration of African Americans misses how poor whites, immigrants, and other people of color are caught in the grip of the carceral state at high rates, due to a highly unequal political economy. The American carceral state is characterized as uniquely hyperpunitive with incarceration rates far exceeding other countries around the world (Wacquant 2009). The United States stands as an outlier for inhumane punishment practices such as incarcerating juveniles with adults in jails and prisons, its exercise of the death penalty, and the use of solitary confinement. 
Alternatively, a neoliberal analysis may neglect an adequate consideration of the ways the political economy is structured along lines of race and is supported by ideologies that systemically disadvantage blacks and other people of color while making the disparities seem natural and normal. Gottschalk (2015) identifies this fissure in Caught: "Much of the work on neoliberalism is not attentive enough to the roles of race, gender, and ethnicity in shaping economic policies. Likewise, much of the literature on race is inattentive to how the sinews of the political economy shape policy and politics" (p. 14).

A race or class analysis of the carceral state fails to create adequate solutions for sprawling state apparatuses of surveillance and punishment by misunderstanding its causes in a nuanced manner. Intra-racial class differences are rarely discussed in relationship to the carceral state, save for more recent works from Fortner (2015) and Forman (2017) who identified the role of African Americans in advocating for and creating punitive criminal justice policies. Positioning the contemporary explosion of prison and jail populations as the sole result of racism also misses that the disparate bearing of the carceral state on African-Americans is not a new phenomenon. Douglass Blackmon (2009) elaborates on the racialized history of the carceral state when he writes, “By 1900, the South's judicial system had been wholly reconfigured to make its primary purpose the coercion of African Americans to comply with the social customs and labor demands of whites.... Sentences were handed down by provincial judges, local mayors, and justices of the peace — often men in the employ of white business owners who relied on the forced labor produced by the judgments" (p. 7) 
To understand why the carceral state has become so vast and expansive since the 1970s requires a broader lens than racial animus and the deployment of the carceral state to socially control black people and perpetuate racial oppression systematically. Comprehending the expansive carceral state also requires a simultaneous attentiveness to the modern neoliberal configuration of the political economy and to economic class. In my thinking, colorblind racism is the contemporary manifestation of racism tied to neoliberalism. Bonilla-Silva (2004) identifies colorblind racism as the new racialized social system resulting from the transformation of the racial structure of the United States that took place in the 1960s and 70s.

According to Bonilla-Silva (2004), "the elements that make up this new racial structure are '(1) the increasingly covert nature of racial discourse and practices; (2) the avoidance of racial terminology and the ever growing claim by whites that they experience 'reverse racism'; the elaboration of a racial agenda over political matters that eschews direct racial references; (4) the invisibility of most mechanisms to reproduce racial inequality; and finally, (5) the rearticulation of a number of racial practices characteristic of the Jim Crow period of race relations." (p. 559).

It is no small coincidence that the dominant progenitor of neoliberal political and economic ideology, Ronald Reagan, was also the first and most politically successful politician to deploy colorblind racial ideology (Weaver, 2015; Alexander, 2010). With his emphasis on individual responsibility and law and order politics, President Reagan invoked and demonized the racially-coded tropes of the welfare queen and criminal as barriers to American progress (Alexander, 2010). Even further, think tanks such as The Manhattan Institute, helped devise urban policies, including broken windows policing 
strategies, grounded in neoliberal principles that also reflect colorblind racism (Camp and Heatherton, 2016; Peck, 2010; Kelly, 2016).

How does broken windows policing connect to the colorblind racism embedded in neoliberalism? It is most often communities of color exhibiting blight due to disinvestment that are identified as disorderly spaces with populations in need of constant surveillance and hyperpunitive interventions. The identification of these spaces as "disorderly" is an example of the covert, racially-coded practices embedded in neoliberalism. Neighborhoods targeted as sites for stop and frisk and broken windows policing practices are hypersegregated precisely because of historical, systematic racial practices such as redlining and urban renewal. When we begin to think about racialized structural processes leading to hypersegregation, the invisibility of mechanisms that produce inequality achieved by colorblind racism are uncovered.

The growth of the carceral state coincides with the economic shifts of deindustrialization, globalization, and the onset of the post-industrial economy marked by growing inequalities (Alexander, 2010; Western, 2006). Current analyses of the carceral state often neglect to parse through a nuanced examination of race, class, and neoliberalism, and to further use an analytical framework that understands them as interconnected. After detailing the perspectives of scholars connecting race and carceral state, and then neoliberalism and the carceral state in greater depth, I will attempt to show how current conceptualizations of race and the political economy can be strengthened and why increased analytical attention should be paid to the intersection between race and class.

\section{Racial Motivation}


In pinpointing the reasons for the swollen carceral state, Marc Mauer (2011) claims the political environment functions as a "top-down" mechanism to create the structure of mass incarceration. Legislative changes creating lengthier sentences for crimes and enhanced sentencing schemes with mandatory minimums generated the 1990s prison boom. Mauer (2011) observes that between the period of 1970 to 2009, "every state expanded its drug offender population, made it easier to try juveniles in adult court, all have adopted some form of mandatory sentencing, all have increased life sentences imposed to record levels" (p. 701). Harsher, lengthier, and more comprehensive surveillance and punishment policies passed with relative ease and near unanimity in state and federal legislatures. Law and order politics continue to sway the American electorate and their representatives.

A contemporary, local example of such punitive legislation is the Kentucky state legislature's recent enactment of HB 169 creating harsher penalties for offenders found to be in a gang (Bailey, 2018). The Kentucky state senate rejected a call from a senator to conduct a racial impact study of the bill, making way for the ultimate signing of it into state law (Bailey, 2018). For Mauer (2011), and other scholars, these types of law and order politics leading to mandatory minimum sentences and increased surveillance are predicated on fomenting racialized hysteria. He explains, "The racial imagery and media sensationalism attendant to the burgeoning crack epidemic pointed unambiguously to punitive responses... Racial imagery and perspectives have framed policy developments not only in regard to perceived offenders but for victims as well" (p. 701-702). 
Similar to the racial motivations presented by Mauer (2011), Michelle Alexander (2010) grounds "tough on crime" initiatives, and more specifically the War on Drugs, in colorblind racism. She identifies mass incarceration as the most recent manifestation of a racial caste system persisting in America from slavery through the Jim Crow era, and there are many compelling dimensions to her argument. Referring to mass incarceration she writes, "Once again in response to a major disruption in the prevailing racial orderthis time the civil rights gains of the 1960s- a new system of racialized social control was created by exploiting the vulnerabilities and racial resentments of poor and working-class whites... The system functioned relatively automatically and the prevailing system of racial meanings, identities, and ideologies already seemed natural" (p. 58).

In her groundbreaking work, Alexander (2010) identifies race as a "political wedge" that divides similarly situated economic classes throughout the course of American history. Writing on the late 1960s following a series of Civil Rights gains that dismantled Jim Crow, she explains, "Race had become, yet again, a powerful wedge, breaking up what had been a solid liberal coalition based on economic interests of the poor and the working and lower-middle classes" (p. 47).

I agree with Alexander's (2010) analysis, but a greater emphasis on the series of economic imperatives tied to racial divisions is a critical point worthy of attention. By economic imperatives I mean inquiring into the economic benefits of the socio-political arrangement and the myriad ways those benefits are accrued. While Alexander (2010) expertly draws out the ideological dimensions of race and racism, not enough attention is paid to its intersection to the political economic structures of society. A political economy framing is important because it shows how ideologically race can "hide the gap" of wide 
economic disparities, particularly those that are intra-racial. Racial ideology disguises the much larger economic gap between poor and affluent whites, a point that Alexander (2010) seems to acknowledge with her "political wedge" arguments but, she still relies on a racial motivation line of argumentation.

A political economy approach considers not only racial politics but the economic imperatives of the carceral state. Again, by economic imperatives I am referring to carceral state outcomes that distribute wealth and influence the overall health of the economy, in a way that reifies existing structural inequalities. The carceral state depresses wages, and according to Western (2007), "generates invisible inequality" (p. 509). Prison inmates are not counted in surveys used to determine employment rates and because of prison, economic expansion in the 90s "did very little to improve the economic status of young black men with no college education" (Western, p. 510). Other economic imperatives include the creation of jobs through the employment of police, the recent proliferation of surveillance technologies created by private companies, and the multimillion-dollar cash bail industry. In early September of 2018, the Philadelphia police ended its civil asset forfeiture program, a practice called "policing for profit" where suspicion of a person's involvement in a crime could lead to their property being confiscated (Mock, 2018). The economic incentives that flow from incarceration, particularly when they reinforce existing race and class inequality, are what I am referring to with the term "economic imperatives."

The analytical approach I propose toward the carceral state acknowledges that the prison explosion has impacted poor people of all races, and that its racial animus extends beyond the social control of black people to achieve a series of economic imperatives tied 
to incarceration. Although, black people have clearly been disproportionately impacted by the carceral state, an empirically demonstrable fact. The unique and almost incomprehensible reach of the carceral state into the lives of black people results, in my estimation, from discriminatory processes set into motion at the founding of the nation. Historical context is critical to understanding the nuances and contours of the carceral state relationship to black Americans, and the hierarchy of race was built into the creation of the nation's political economy. This is a topic I take up in a more extended discussion of race later in this chapter when I present an alternative framework.

Opening the door to a discussion of the clear material benefits of incarceration and mass criminalization in addition to race, can help us understand the current boom in private prisons for immigration detention and ICE roundups as a parallel phenomenon fueled by the similar carceral state processes, and its victims as more than just collateral damage. The day after Donald Trump's victory in the presidential elections, Corrections Corp. shares rose $60 \%$ and another private prison company, GEO Group Inc., saw a $18 \%$ jump in share prices, all by 10:14am on November $9^{\text {th }}$ (Alloway and Katz, 2016). Racially-incendiary campaign promises about cracking down on "illegal immigration" through law and order, came to fruition through ICE round-ups and child separations at the border. Racial ideology naturalized and normalized these inhumane carceral state practices that rendered people suspicious and criminalized them primarily on the basis of their race.

Alexander (2010) firmly grounds the spectacle of mass incarceration in the contemporary era of colorblind racism and sees it as a phenomenon generated by processes specifically designed to target black people. As defined by sociology scholar 
Bonilla-Silva (2014), colorblind racism is the post-Jim Crow era manifestation of racial ideology and racial structures relying on racially-coded frames. Colorblind racism uses what Charles Lawrence (1987) would call "social text;" what society implicitly understands about and associates with blackness and black people, to invoke racial thinking without ever explicitly mentioning race. The frames of colorblind racism perform the important ideological work of justifying racial inequalities in society as natural and normal.

The relationship between colorblind racism and mass incarceration is often supported by contentions that the face of crime in America has become equated with young, black males. Detailed by scholars such as Khalil Gibran Muhammad (2011) and Sophie Body-Gendrot (2011), the argument follows that young black men in particular and blackness more generally is criminalized in media and in popular discourse. In turn, these racial ideologies about blackness influence the society-wide acceptance of law and order politics. Wacquant (2002) wrote, "The conflation of blackness and crime in collective representation and government policy... thus reactivates race by giving a legitimate outlet to the expression of anti-black animus in the form of public vituperation of criminals and prisoners" (p. 56).

Scholars conceptualize the racial motivation behind the carceral state not only as racial ideologies used as "dog whistle" political strategies, to use the language of Ian Haney Lopez (2015), but also as occurring through criminal actors with discretion making racially biased decisions either explicitly or implicitly. Paul Butler (2017) argues law, social practices, and policies are unambiguously designed to manage the AfricanAmerican male threat, via overt state violence for the purpose of social control. 
He describes a series of criminal justice system stakeholders, police, judges, and prosecutors, as participants in a racially driven "Chokehold," predicated on controlling the perceived black male threat. He writes, "The Chokehold is the legal and social response. It contains a constellation of tools that are used to keep them down- including a range of social practices, laws, punishments and technologies that mark every black man as a thug or potential thug. The state- especially the police- is authorized to control them by any means necessary" (p. xiii).

I find Butler's (2017) arguments compelling, but one aspect of the Chokehold, as with The New Jim Crow, remain underexplored- the economic imperatives tied to the racialized criminal justice system and its connection to the political economy. He writes, "anti-blackness is instrumental rather than emotional. As slaves built the White House, the Chokehold builds the wealth of white elites. Discriminatory law enforcement practices such as stop and frisk, mass incarceration, and the war on drugs are key components of the political economy of the United States" (xi). The instrumentality of the deployment of the carceral state to achieve economic ends requires greater attention, and it impacts people of all races, although admittedly not equally.

In Crook County, Nicole Gonzalez Van Cleeve (2016) describes the local court as a racialized habitus functioning to replicate and reinforce segregation and inequality along lines of race. In her ethnography of the Cook County criminal court system, she writes, "imbued with legal authority, power, and institutional legitimacy, the doing of colorblind racism transforms into state sanctioned racial degradation ceremonies" ( $\mathrm{p}$. 186). Her work identifies the ways racial ideology, and colorblind racism, are carried out through individuals who comprise the criminal justice system, particularly in prosecutor 
offices. She argues institutionalized patterns of segregation between the attorneys and other court staff systematically processing defendants perpetuates racism in structural ways (Van Cleeve 2016).

Van Cleeve's (2016) work is incredibly important because it shows how racial ideology is manifested and reproduced in institutions through actors with decisionmaking power and is tied to structural racism that perpetuates hierarchies through the exercise of institutionally-backed power. Her framework, however, relies solely on racial animus and is complicated by the ubiquity of black judges, prosecutors, and other criminal justice actors in a number of urban centers.

There is much support for the racial motivation perspective on the carceral state, as there are what seems to be an almost boundless number of empirically evidenced racially disparate outcomes at the hands of the carceral state. At all points of contact from police stops and arrests to sentencing, African Americans consistently experience more negative outcomes. Whites fare better in the plea-bargaining process, largely controlled by prosecutors, in comparison to similarly situated black defendants (Alexander, 2010). In numerous jurisdictions black drivers are more likely to be arrested, fined, and given citations (Vega, 2016; U.S. Dept. of Justice, 2015; Cole, 1999). Including cities such as Chicago and Los-Angeles, at least 1,561 police departments across the United States arrest black people at rates 3 times or higher than people of other races (Heath, 2014). A recent New York Times op-ed read: “African-Americans are disproportionately arrested for jaywalking and other small-scale offenses nationwide. Sacramento police issued more than 200 tickets for jaywalking last year in the neighborhoods of North Sacramento and Del Paso Heights. While just 15 percent of residents of that area are African-American, 
black residents made up around 50 percent of those ticketed. In Urbana, Ill., the disparity was even starker: From 2007 to 2011, 91 percent of those ticketed for jaywalking were black, in an area where just 16 percent of residents are African-American" (Coaston, 2017).

While some scholars focus on implicit bias, discrimination that is clearly outwardly racist continues to persist. The Ferguson Department of Justice Report revealed municipal and law enforcement practices resulted from the intentional racial discrimination of system actors. These racist ideas were found in the communications of court staff and one email circulated in the court system, "joked about an abortion by an African-American woman being a means of crime control" (p. 5) this quote further reinforces the connection between blackness and criminality.

For racial motivation scholars, however, the carceral state is explicitly and implicitly a racial project whether perpetrated by racist politics, racially biased actors, or race-motivated systems. The focus of this body of literature is resoundingly about racialized social control. Race constitutes the primary analytical frame for understanding mass criminalization in a way that is inadequately attentive to the political economy. Truly grasping the scope and impact of mass criminalization requires an analysis that considers the economic imperatives of the carceral state, impacting all sectors of society across the board. The explosion has been made possible and globally disproportionate because of the exorbitant rate of punishment and incarceration impacting all races and poor people.

New data from the Bureau of Justice statistics shows that since 2009, the gap between black and white prisoners has declined by almost half (Gramlich, 2018). When 
we only consider the disproportionate rate of the incarceration of black people, we also miss that in some jurisdictions white inmates and arrestees comprise the majority of those incarcerated. Kentucky is a primary example, black people are 3.2 times more likely to be in prison than whites but, the majority of inmates in the state are white (Spalding, 2016). Both Alexander (2010) and Butler (2017) acknowledge non-black incarceration, but both explain the incarceration of whites and other minorities as collateral damage. As Butler (2017) writes, "many other people- including African American women, immigrants, poor white people, Muslims, and Native Americans- are caught in its snares, but they are collateral damage of a process that is designed for black men" (p. 1).

For these scholars, the disproportionate rate of black incarceration and clear racial biases at all points of discretion show black people are the intended target of the carceral state and all others happen to be bystanders caught within the net of the sprawling criminal justice system predicated on anti-black racism. I find this articulation to be wholly insufficient in explaining the large numbers of Latinos, poor whites, and other racial groups incarcerated or criminalized by the expansive American carceral state. As Marie Gottschalk (2015) noted, “[p]oor whites, Hispanics, and women have been a booming area for the carceral state" (p. 5). Recent studies show a prison boom is occurring in rural, predominately white counties (Keller and Pearce, 2016). I argue other racial groups and poor whites becoming ensnared by the massive carceral state is also by design as part of the structure of the American political economy. In the contemporary era, the American political economy is dominated by an ideological and policy framework of neoliberalism. 
What is a key point from racial motivation scholars, however, is the persistence of systematically disproportionate racial outcomes. Alexander (2010), Butler (2017), and other scholars genealogically link slavery to the Jim Crow era to modern day mass incarceration. While positioning mass criminalization in this way does much to elucidate black American citizenship experiences, it also provides a helpful frame for exploring the linkages between race and the political economy in America. Racial motivation scholars tend to articulate the racism of the criminal justice system as a form of social control. I would offer an additional framing that acknowledges the ways in which black incarceration and subjugation has been incentivized since the founding of the nation. In each of these eras racial ideology supported the detention and incarceration of black bodies in support of a political economy that has made these practices lucrative. Therefore, there is a racial "chokehold" by design but, my position is that this social control is designed to achieve primarily economic outcomes.

The racial motivation strain cannot fully and adequately account for the massive expansion of the American carceral state because the hyperincarceration and control of black bodies through legal mechanisms dates back to the founding of the country. The first American prison boom occurred during Reconstruction. Between 1850 and 1870 the incarceration of African Americans in Alabama alone exploded from 2\% of the prison population to 74\% (Haney-Lopez, 2015).

The racial motivation argument is also complicated by the actions of black elected officials and community members who advocate for tough on crime, law and order policies as well as system actors of color such as police, judges, and prosecutors replicating racially biased outcomes. James Foreman, Jr. (2017) argues that class 
divisions within the black community represent an underexplored dimension of the criminal justice system. His book Locking up Our Own, reviews the role of black political leadership, primarily in Washington D.C., in enhancing and supporting the carceral state. As examples he highlights tough on crime policies such as harsher penalties for gun possession, opposition to the decriminalization of marijuana, and also the call to hire more black police officers from the African American community.

Similarly, Michael Javen Fortner (2015) explored the role of working and middleclass African Americans, what he terms the Black Silent Majority, in advocating for harsher penalties and increased policing that contributed to mass incarceration using New York's Rockefeller drug laws as an example. Writing on Harlem in the early 1970s Fortner (2015) explains, "Caught in the throes of urban decline and social disorganization, working and middle-class African Americans were under siege and overwrought. Their 'respectable' lives, which they had worked so hard to create, were now being jeopardized by ne'er to-do-wells stealing their property and accosting their person... they now believed policing and prisons- the systematic removal of junkiesrepresented their own path to salvation" (p. 149).

These texts remind me of my own time as a public defender in New Orleans, Louisiana, a stronghold for black political power. Yet, in New Orleans one in every 14 black men is incarcerated and one in 7 is either in prison, on probation or parole (Chang, 2017). Many of the judges I practiced in front of were African American. A large number of correctional staff at the infamous Orleans Parish Prison were also black. The elected Sheriff Marlin Gusman, who advocated for building a new jail in the city, is also African American. The jail, whose plans were later scaled back, resulted from an initial request 
from Gusman to provide for 5,000 new inmate beds, one for every 60 residents of the city. As of late 2017, the city's Metropolitan Crime Commission issued a report that inmate totals at the now two-year-old $\$ 145$ million facility exceeded its capacity, and more than the existing 1,438 beds were needed (Lane, 2017).

The police department also includes a majority of black officers in its ranks and in 2016, 57\% of the NOPD identified as black (Simerman, 2016). The New Orleans Police Department was the subject of a Department of Justice investigative report issued in 2011 (U.S. Dept. of Justice, 2011). The report found the NOPD engaged in unconstitutional patterns and practices in the use of force, stops, searches, and arrests, and engaged in discriminatory policing (U.S. Dept. of Justice, 2011). In the days following Hurricane Katrina, New Orleans police officers fatally shot and killed Henry Glover, then burned his body in a car. In a separate incident, police shot and killed two people and injured others in what came to be known as the Danziger Bridge incident. Two of the ten officers facing federal charges for these crimes were officers of color (Times-Picayune Staff, 2011). Not only were many of the carceral state stakeholders African American, but the city is also a stronghold for black political representation. From 1978 until 2010, New Orleans elected a black mayor, and an African American woman was elected mayor in 2017.

The recent texts from Forman (2017) and Fortner (2015) exploring class divisions among African Americans illustrate a conservative strand of law-and-order politics existing in the black community. These works highlighting the role of black political leadership in enhancing mass criminalization complicate the narrative around the carceral state and race as a mechanism used to primarily socially control black people. Too many 
dialogues about race present black people as a monolithic group with little to no attentiveness to the role of class in differentiating populations that share the same race. Racial motivations cannot entirely account for the expansiveness of the carceral state.

This strain of literature from Fortner (2015) and Forman (2017) shows how economic considerations, for example black police officers who want a decent middleclass wage, and other class dynamics influence perceptions of law and order in addition

to race. Their work shows that black people, despite primarily voting Democrat, can and do have conservative political views, and this also speaks to the bipartisan nature of law and order politics that crosses party lines. The role of black people in contributing to mass incarceration also highlights the importance of paying attention to neoliberal policies and their role in escalating incarceration and carceral state surveillance.

\section{Neoliberal Political Economy}

An alternative explanation for the expansive carceral state is the onset of the neoliberal political economy. The literature on neoliberalism attaches the concept to a variety of phenomena making the concept difficult to define. The most commonly accepted definition of "neoliberal" references policies centered on decreased social welfare spending, a preference for privatization, and the facilitation of increased freemarket trade and capital investment (Brenner and Theodore, 2002; Peck and Tickell, 2002; Harvey, 2005; Herbert and Brown, 2006; Samara, 2012). Weaver (2016) defines neoliberalism as, "A political-economic theory and rhetorical framework that rests on the notion that freedom, justice, and well-being are best guaranteed by a political-economic system, undergirded by the state, which promotes private property (including via 
privatization of state assets), open markets, and free trade and which privileges the interests of financial capital above all” (p. 11).

Neoliberalism favors the free-market as the primary form of governance. The oftused phrase refers to an ideology, a form of governance and the institutional imperatives it rolls-out. Jamie Peck (2010) identifies neoliberalization as, "an open-ended and contradictory process of regulatory restructuring... the closest one can get to understanding neoliberalism is to follow its movements, and to triangulate between its ideological, ideational, and institutional currents" (p. 7-8). Neoliberalism is an expansion of much older ideas about free-market competition and privatization, but its discourse has come to dominate policy-making over the past forty-years (Brenner and Theodore, 2002). According to Peck (2010): "It was the 1970, of course, when the dominoes began to fall in the direction of market-oriented reform... it was the extended macroeconomic travails of the 1970s, especially in the United States and the United Kingdom, which represented the historical opening for which the neoliberal script had been painstakingly constructed. Stagflation broke the back of the Keynesian orthodoxy- both as a generative theory and as a system of government" (p. 5).

Neoliberalism as a governance ideology would seem to eschew the trend of a ballooning carceral state. After all, neoliberalism is characterized by a free-market reigns philosophy and endeavors to "hollow" out the state by providing government services through private actors. There have been a number of carceral state functions that have been privatized: private prisons, the supervisory functions of probation and parole, the private bail bond market, and electronic monitoring companies are a few examples. 
Four threads of neoliberal literature aid in understanding the carceral state expansion. The state restructuring view argues that as the social wing of the state came to be dismantled, the state's surveillance and punishment capacities grew to manage the resulting economic insecurity and inequality (LeBaron and Roberts, 2010; Wacquant, 2009). Second, neoliberalism strongly espouses the rhetoric of individual responsibility (particularly for the poor) that makes harsh, punitive state interventions acceptable (Peck, 2010; Ishwata, 2011). Third, neoliberalism drives policy in various city government institutions, including local police departments, through its vision for city space that focuses on capital accumulation (Weber, 2002). Finally, Ruth Gilmore (2007), although she does not use the phrasing of neoliberalism, describes the California prison explosion as the result of the state's political economy and argues the prison buildup was the choice of political leaders and the electorate to resolve capital surpluses (2007). I mention Gilmore (2007) because her work is instructive on how and why a consideration of the political economy is critical to an analysis of mass incarceration. In the paragraphs that follow, each of these connections between the carceral state and neoliberalism will be explored.

Wacquant (2009) conceives of mass incarceration as resulting from neoliberal state restructuring, arguing the state is a "centaur" characterized by a dismantling of its economic and social welfare arms, while simultaneously expanding its penal fist. In Prisons of Poverty he argues, "The expansive and expensive penal system is not just a consequence of neoliberalism... but an integral component of the neoliberal state itself" (p. 175). For Wacquant, the punitive carceral state has functioned to warehouse groups disenfranchised by the post-industrial economy and the diminishing welfare state. He is 
further attentive to the contradictory nature of neoliberalism's expansive carceral wing, writing, "The same parties, politicians, pundits, and professors who yesterday mobilized, with remarkable success, in support of 'less government' as concerns the prerogatives of capital and the deployment of labor are now demanding, with every bit as much fervor, 'more government' to mask and contain the deleterious social consequences, in the lower regions of social space, of the deregulation of wage work and the deterioration of social protection" (p. 11).

According to LeBaron and Roberts (2010), criminalization and incarceration are mechanisms for managing insecurities arising from neoliberal social and economic policies. Western (2006) helps document the collision between mass imprisonment and the decline in the availability of work in cities. He writes, "Mass imprisonment of the late 1990s can be traced to a rightward shift in American politics and the collapse of the urban labor market for low skill men... Urban deindustrialization eroded the labor market for unskilled men while punitive politics gained momentum in the 1970 s and 80 s... When punitive criminal justice policy collided with the jobless ghetto, the prison population swelled. Prison admission rates climbed with the jobless rates for black men” (p. 31). Writing with Katherine Beckett previously in 2001, Western described welfare and penal institutions as comprising, "a single policy regime aimed at the governance of social marginality" (p. 44). Western's research provides empirical support for the state restructuring argument made by Wacquant in regard to neoliberalism- that it entails a rolling back of the welfare state and heightened carceral state punishments to manage poverty in response to a political economy marked by growing inequality. 
While the logic of neoliberalism favors less government intervention in the free market in regard to capital, it has an additional strand that implements state punishment and incarceration as correctives for behavior deemed untenable in the free market. The neoliberal advocacy for state surveillance and retribution that relies on a philosophy of individual responsibility is heavily targeted toward the poor. The proliferation of activities and actions defined as illegal result from a sharply drawn boundary of acceptable, rational behavior. What Harcourt (2009) calls "neoliberal penality" is explained as, "a form of rationality in which the penal sphere is pushed outside political economy and serves the function of a boundary: the penal sanction is marked off from the dominant logic of classical economics as the only space where order is legitimately enforced by the state" (p. 77).

Increasingly this boundary has been drawn in a way that functions to criminalize poverty (Mitchell, 2003). Don Mitchell (2003) grounded proliferating city ordinances criminalizing homelessness in ideas of what constitutes a "disorderly space" requiring regulation and state intervention. A neoliberal logic places a premium on order in urban space in order to reduce crime and increase the investment and exchange value of urban land in the market. Mayer (2007) explains, "cities today are confronting a more competitive (global) environment, and local governments have taken to place-marketing, enterprise zones, tax abatements, public-private public partnerships, and new forms of local boosterism- but also have reached out for new strategies of social control and workfare policies. Urban forms of governance have become entrepreneurialized, emphasizing economic efficiency, low taxes, individual responsibility, and user fees; the 
most important goal of urban policy has become to mobilize city space as an arena for market-oriented growth" (p. 91).

In turn, this has shaped urban crime control through a re-emergence of order maintenance policing practices, focused on petty, low-level activity. In the broken windows policing era, the conceptualization of urban space as requiring order has led to strong sanctions, including arrest, for even the smallest of perceived criminal violations such as possessing an open container, loitering, and criminal trespass (Camp and Heatherton, 2016; Kelly, 2016). These disciplinary law and order measures operate to criminalize minor of behaviors and target the poor. Camp and Heatherton explain in 2016, "As deindustrialized cities have become veritable landscapes of broken windowsreplete with abandoned homes, job sites, and factories- policy makers and police departments have utilized the logic of broken windows to locate disorder within individuals, off-loading liability onto the bodies of the blamed." Herbert and Brown (2006) connected policing strategies to a neoliberal view of city space. They argue broken windows policing strategies are an example of, "the political culture of hyperpunitiveness that is a striking feature of neoliberalism" (p. 757).

In Constructions of Neoliberal Reason, Peck (2010), identifies the neoliberal think tank, the Manhattan Institute, for its role in propagating broken windows policing as urban government policy. He writes, “According to the 'broken windows' thesis of George Kelling, disorderly neighborhood environments serve as incubators for both fear and crime, the appropriate response to which is relentless, street-level policing of all forms of public order including prostitution, public urination, vandalism, fare-dodging, panhandling, and vagrancy" (144-145). The neoliberal perception of urban space and 
disorder that has spawned the zero tolerance policing approaches described above is undergirded by a philosophy that views city space for its profitability in the market.

Lastly, Ruth Gilmore (2007) identifies the prison industrial complex buildup in California as a spatial fix for, "surpluses of finance capital, land, labor, and state capacity" (p. 88). In focusing on one state and the changes its economy and politics that facilitated prison expansion, Gilmore (2007) provides one of the most nuanced accounts of the expansion of mass incarceration. She identifies a series of "contradictory processes at work in the 1982 transition year from the lapsed welfare-state Democratic to the supply-side Republican gubernatorial regime” (p. 93). Without using the terminology of neoliberalism, Gilmore (2007) highlights the push of newly elected Governor George Deukmejian to target persons receiving welfare and his use of racial pleas to advocate for a prison plan that focused on punishment in the form of incapacitation (Gilmore, 2007). For Gilmore, "prisons are partial geographical solutions to political economic crises, organized by the state, which is itself in crisis... the instability that characterized the end of the golden age of American capitalism, provide[d] a key" (p. 26). Gilmore also provides some attentiveness to race in her writing as well with her acknowledgement that prison demographics are constituted by the, "working or workless poor, most of whom are not white" (p. 15).

\section{Analytical Gaps in the Literature}

Understanding the interconnection between race and neoliberalism is critical to developing solutions to the expansive reach of the carceral state. Viewing the mass 
criminalization explosion as the result of structural developments helps show that reform efforts may be helpful but insufficient. For example, modifying specific carceral state practices like sentencing and bail may alone be inadequate to transform the system and roll back the carceral state if its expansion is the result of systemic processes embedded in the political economy. The recent community organizer strategy to bail out defendants who cannot afford their release has tangible impacts on those who are able to return home but, the cash bail system remains intact and many more will enter into the system through arrest.

Another way an either/or analysis is incomplete is, if the expansion of the carceral state is predicated on racial animus and implicit bias, then greater diversity among actors in the criminal justice system and trainings centered on reducing bias could be conceived of as a sufficient response to the problem. But, as my own experiences in New Orleans and the work of Foreman (2017) and Fortner (2015) show, this is not the case.

Alternatively, focusing solely on diminishing racial inequalities conceals the role of the neoliberal carceral state in managing social insecurity and warehousing surplus labor in the context of growing economic inequality. An understanding of the historically disparate impact of the carceral state where African Americans are concerned would also seem to indicate greater structural changes to the overall hierarchical organization of the political economy are needed to alleviate the problem of mass criminalization. If we begin to understand the modern carceral system as the result of a racialized political economy, in its current post-industrial, neoliberal configuration then simply changing the actors or pursuing reform-based policy measures will not dramatically alter outcomes because these outcomes are part of the hierarchy of the economic and political system. 


\section{Mass Incarceration \& the Crime Wave of the 1960s}

There are alternative explanations for the mass incarceration explosion and one is the tidal wave of crime beginning in the 1960s, for which New York City became the urban posterchild. During the era of the late 60s to the 80s crime in America rapidly increased and there was a real, palpable fear surrounding it. Between 1960 and 1970 the violent crime rate increased $126 \%$ and over the course of the following decade it increased 64\% (Eisen and Roeder, 2015). Steve Pinker (2013) wrote, "The rebounding of violence in the 1960s defied every expectation. The decade was a time of unprecedented economic growth, nearly full employment, levels of economic equality for which people today are nostalgic, historic racial progress, and the blossoming of government social programs" (para. 4).

In response to the crime wave, one of the most influential political scientists, James Q. Wilson, co-penned an article in The Atlantic Monthly magazine with George Keller from the Manhattan Institute titled "Broken Windows” (1982). Recently, former New York Mayor Rudy Giuliani lauded Wilson and Keller's approach to the marked increases in crime writing, "I began, with police commissioner Bill Bratton, to focus on the squeegee guys who disturbed and frightened visitors to the city, wiping down their windshields and demanding payment. We had assumed that there were hundreds but found that in reality there were just a handful. We moved them off the streets, and there was an immediate feeling that low-level criminals were no longer in control and that New York City was livable again" (Giuliani, 2012, para. 5). 
Wilson's influential ideas were soundly rooted in the principles of deterrence through harsh punishment for convictions and incapacitation that separated criminals from the rest of society (Wilson, 1976). The hyperpunitive approach advocated for by Wilson as a response to the increase in crime were also discussed in Forman's (2017) and Fortner's (2015) texts as the reasonable rejoinder to escalating violent crime for many black community members. Here, we see that in both academic circles and among African-Americans experiencing the brunt of the violent crime increase, heightened police presence and incarceration were the preferred responses to the problem.

\section{An Alternative Framework: Discriminatory Design \& the Intersection between Neoliberalism \& Colorblind Racism}

The above discussions of race and neoliberalism endeavored to explain and then highlight the shortcomings for each of the theoretical approaches to mass incarceration and criminalization. In this section, I seek to rectify some of these gaps through an alternative analytical framework that combines colorblind racism and neoliberalism. Here is where I attempt to grapple with some of the either/or juxtapositions in the literature and clearly detail the way I approach an understanding of the carceral state explosion. In line with the contention that race is an essential structural component to the American political economy, I view colorblind racism and neoliberalism as inseparable.

I think of the contemporary colorblind manifestation of racism as part and parcel of the neoliberal political and economic project that has proliferated since the 1970s. Long-standing racial ideologies in their colorblind manifestation fit neatly within a neoliberal articulation of poverty as resulting from a lack of individual responsibility. 
And, the racial dimension of neoliberalism colors non-white communities as requiring heightened state surveillance without explicitly naming race.

Without an understanding of racial history and its connection to political and economic developments, however, we are unable to provide context to the most recent configurations of race in the political economy. Many of the disparate patterns in policing and criminal justice we see in the contemporary carceral state were present pre-mass incarceration. Here I bring to bear Ruha Benjamin's (2016) notion of “discriminatory design" on the systematic racial disparities of the carceral state.

Although she was referencing technological developments, Benjamin (2016) explains discriminatory design, "normalizes racial hierarchies- not as an ideological aberration from business-as-usual, but as an economic imperative that is built in to the machine. One need not harbor any racial animus to exercise racism in this and so many other contexts; rather when the default settings have been stipulated, simply doing one's job... is enough to ensure the consistency of white domination over time. Likewise, changing individual sentiment from animus to tolerance, or even affection, will not transform the status quo so long as the underlying design of our socio-technical world is left in place" (p. 148).

To help illustrate "discriminatory design" in the carceral state, similar to Alexander (2010) and Butler (2017), I revisit prior historic systems of racial social control. I attempt to supplement their work by pinpointing some of the economic and social functions of race while doing so. I use this historical perspective to make two main overarching claims about race and the carceral state and its connection to the political economy that are present in the phenomenon of mass criminalization. These claims are 
that racism has both ideological and structural dimensions that require attention to dismantle its role in society, and that race performs a "masking function" that conceals the functioning of a hierarchical economy shaped like a pyramid by design. First, I begin with a discussion of how colorblind racism is embedded in neoliberalism both ideologically and structurally.

\section{The Colorblind Racism Embedded in Neoliberalism}

There are a handful of scholars who address the connection between neoliberalism and race but construe its interconnection in a myriad of ways. Omi and Winant (2015) articulate neoliberalism as a racial political project that tapped into white supremacy to justify an assault on the welfare state. They identify two neoliberal policies, tax revolt and producerism, as arising from racial resentment (Omi \& Winant, 2015). They write, "Tax revolt spread rapidly as a national movement. This was a delicious dish for the Republican Party to serve in the suburbs, since it focused (white) popular resentment of poor people, which in the national popular culture meant black people" (Omi \& Winant, p. 215).

This is an argument similar to the one Ian Haney-Lopez (2015) seeks to make in Dog Whistle Politics, that colorblind racism garnered support for regressive policies that over time decimated the economic standing of the middle class. He writes, "Politicians backed by concentrated wealth manipulate racial appeals to win elections and also to win support for regressive policies that help corporations and the super-rich, and in the process wreck the middle class" (p. xii). Haney-Lopez (2015) defines "strategic racism" 
as, "[the] purposeful efforts to use racial animus as leverage to gain material wealth, political power, or heightened social standing" (46). I find this to be a critical intersection between race and class, that whites relay economic anxieties on to non-white minority groups and take political positions that prop up a highly unequal economic order that concentrates wealth in the hands of a few.

Christopher Mele (2013) discussed interconnections between neoliberalism and colorblind racism that are explicitly urban. In his analysis of urban development projects, he argued, "what color-blind racial discourse does provide is the underlying basis of legitimacy for the planning, implementation and promotion of neoliberal urban policies and practices that reproduce and enhance sociospatial inequality... Color-blind racial discourses facilitate the agenda and mandates behind tax abatements, enterprise zones, public-private partnerships, and related redevelopment policies and practices" (p. 599600). For Eric Ishwata (2011), "colorblind racism has effectively recoded the incongruent effects of racism in stringently individual and non-racial terms" (p. 35-36). And, for De Lissovoy (2012), “neoliberalism's aggressively race-blind framework for understanding social inequality has the effect of de-emphasizing structural disparities and constructing race-based analyses as themselves pernicious in their attention to race as a salient category of social experience (p. 743).

Gottschalk (2015) notes the United States manifestation of neoliberalism is heavily influenced by race. Understanding the role of colorblind racism as connected to the neoliberal project is important for analytical reasons and is instructive on the integrated relationship between race and class in the U.S. society. Colorblind racism is how race is articulated in the context of a neoliberal political economy that has always 
maintained a racial element. Taking a cue from Adolph Reed (2013), the content of race as an ideology has "changed markedly over time in relation to changing political and economic conditions" (p. 51). Writing on Britain, Gilroy (2005) explained, "Racism is a contradictory phenomenon which is constantly transformed, along with the wider political-economic structures and relations of the social formation... Racism is always historically specific in this way" (pg. 12, 26).

In the U.S., these changes in the racial structure of the United States can be mapped in three major epochs from enslavement to Jim Crow to the postindustrial era of mass incarceration. Major structural economic and political changes brought about overhauls to the American racial structure while simultaneously maintaining certain ideological tenets of race and keeping a hierarchical organization intact. In their work Racial Formation, Omi and Winant identify race as a malleable, ever changing construct (2014). Racial formation, according to Reed (2013), "has always been an aspect of class formation, as a 'social condition of production.' Race has been a constitutive element in a capitalist social dynamic in which 'social types (instead of persons) figure as basic units of economic and political management' ... Race is similarly a function- a relation of hierarchy rooted in the capitalist division of labor- turned into an object” (p. 51).

Racial animus among state agents reflect the powerful sway of the ideological dimension of race, but the unequal outcomes of the carceral state do not rest solely on individual prejudice or intentional racial discrimination. When a discussion of the carceral state is contextualized in the political economy, it reveals an economic imperative in the same way enslavement and Jim Crow did. Fines and fees in the era of 
austerity are one element of this economic imperative; the warehousing and management of surplus labor in the postindustrial era is another.

The point I am seeking to make here is that racial discrimination is built into the political economy by design and continues to systematically replicate and regenerate in political institutions and the economy. More specifically, as detailed previously, the legal machinery of the nation and its states were explicitly discriminatory by design to invoke the terminology used by Benjamin (2016). Yet, to focus solely on race, and particularly anti-black racism, serves to mask political economic processes that disenfranchise poor whites as well and concentrates wealth at the top of the pyramid. A racial analysis that fails to pay serious attention to class misses the broader disenfranchising functions of the economic order.

Derrick Bell (1991) describes this much more eloquently than I when he writes, "discrimination based on race disguises the more subtle though hardly less pernicious class-based disadvantage suffered by many whites. The compulsive attention given to the whites' superior status compared to that of those blacks in the lowest socio-economic ranks obscures the far more sizeable gap between the status of most whites and those who occupy the lofty top levels of our society" (p. 269).

Bruce Western (2006) further illustrates this point in a way that is specific to the carceral state, "the largest effects of incarceration on aggregate patterns of inequality were within the black population. The income gap and the gap in marriage rates between middle class and poor blacks would be significantly smaller, but for the effects of incarceration. In this way, mass imprisonment has institutionalized the marginality of 
poor blacks, setting them apart from white society and crystallizing social inequality within the African-American community" (p. 36).

\section{Discriminatory Design \& the Carceral State}

In what follows, I attempt to lay out the argument for why discriminatory design is apparent in the American carceral state by pinpointing three specific configurations of race and the political economy that have persisted over time. In the introductory chapter, I cited a quote from Douglass Blackmon (2009), “By 1900, the South's judicial system had been wholly reconfigured to make its primary purpose the coercion of African Americans to comply with the social customs and labor demands of whites.... Sentences were handed down by provincial judges, local mayors, and justices of the peace - often men in the employ of white business owners who relied on the forced labor produced by the judgments" (p. 7). Blackmon's (2009) quote highlights three critical points related to the carceral state post-Emancipation. It shows the carceral state was comprised of explicitly raced institutions that promulgated laws and practices specifically targeting African Americans based on an ideology of black inferiority. It demonstrates the carceral state achieved the social control of black people in accordance with Jim Crow social norms that granted whites cultural and psychological superiority. Lastly, the observation from Blackmon (2009) highlights the carceral state role in supporting an economy predicated on the subjugation of black labor. I discuss each of these key points in depth using historical examples, because these hallmarks of the racialized carceral state provide 
a helpful frame for understanding the connection between race, the political economy, and the carceral state in the present era of mass criminalization.

The Persistence of the Ideology of Black Inferiority in the Law

The American legal system, and the country itself, was birthed in the context of black enslavement and subjugation; it was created as a slaveholder's nation (Higginbotham, 1996; Websdale, 2001; Buck, 2017). Higginbotham’s (1996) work Shades of Freedom, argues that the precept of black inferiority was foundational to American law as he tracks legal decisions overtime from colonial America to Reconstruction to demonstrate how white supremacy was created and sanctioned by the judiciary and legislatures alike.

Colonial governments created distinctions between whites and blacks through affording privileges to whites that were denied to blacks such as the right to bear arms, gather in groups, and tying the enslaved status of the mother to her children (Higginbotham, 1996). Less than a decade before the Civil War, the 1857 Dredd Scott decision explicitly sanctioned white supremacy when the highest court in America declared that black people had no rights that whites were bound to respect (Dred Scott v. Sandford, 1857).

These legal enactments highlight the institutional adoption and the enshrinement of the idea of white supremacy in the law at the founding of the nation. The hierarchical organization of society it spawned that has persisted overtime. Tim Weaver's (2015), important nod to the key role of ideas in generating policies and political mandates is 
instructive on the embeddedness of race in institutions interpreting, implementing, and creating American law. Weaver identifies four stages in the process from ideas to political development. An idea must be present, clearly expressed by politically relevant actors, adopted by key political officials with the institutional tools of government, and to be introduced and institutionally embedded. The drafters of the American Constitution were slaveholders, who sought to protect the institution of enslavement in the founding legal document of the country. (Higginbotham, 1996). The idea of white supremacy was institutionally embedded at the founding of the country and was tied to an economic system predicated on the exploitation of black labor.

The ideology of blacks as an inferior, malleable labor force persisted beyond enslavement, and the carceral state played an integral role in maintaining the hierarchical social, economic, and political order. CLR James (2012) explained that the civil war was not sparked by a new-found morality over the issue of racialized enslavement but by the onset of the industrial revolution globally. The post-Civil War era brought with it the first American prison boom. According to Haney-Lopez (2015), the convict leasing system created during this time specifically, "functioned to protect the white financial interests jeopardized by slavery's end and also was crafted to shore up white domination over blacks in the new post-slavery world" (p. 46).

While the wake of the Civil War brought with it constitutional amendments and legislative enactments that changed the citizenship status and civil rights of black people in the United States, a series of Supreme Court decisions would roll back their effectiveness and limit their application for almost 100 years until Brown v. Board overturned the separate but equal doctrine of the 1896 decision Plessy v. Ferguson 
(Higginbotham, 1996). The 1883 Civil Rights Cases found the 1875 Civil Rights Act that granted equal access to public accommodations unconstitutional, and the Court consistently declined to grant federal jurisdiction to protect citizenship rights that southern states consistently violated (Higginbotham, 1996).

Jim Crow is a critical era in which to view the American carceral state specifically because it arose in the wake of an antebellum economy predicated on black subjugation. The hierarchical racial order that generated profits from black bodies during slavery was refashioned, but it was not dismantled. Higginbotham argued that in the wake of enslavement, the legal machinery of the United States was unable to break from the precept of black inferiority. (Higginbotham, 1996).

According to Bruce Western (2006), "We can read the story of mass imprisonment as part of the African American citizenship story. Each piece of the storypervasive incarceration, unemployment, family instability- shows how mass imprisonment has created a novel social experience for disadvantaged blacks that is wholly outside of the mainstream social life" (p. 193). Yet, the criminal justice system and carceral state has long stood as a measure of citizenship for black people. Cases like the Scottsboro Boys, where 9 black men were accused of and convicted of raping two white women on a train, sparked international attention because it highlighted the racism of the southern criminal justice system (King, 2012). The convict leasing system and systematic impunity for perpetrators of lynchings and violence against black people also illustrate the criminal justice system's role in shaping black American citizenship experiences historically. 


\section{The Cultural \& Psychological Role of Racism}

Imani Perry (2011) identified "racial practices of inequality" as "clear decisions to disadvantage others on the basis of race" and "there are undeniable patterns of racial privileging and disadvantage that are part of contemporary American culture" (p. 7-8). Perry (2011) explains the racial inequality as a "national cultural practice" that includes, "common ways of thinking that are reflective of a racial ideology and that sustain a belief in or an assumption of White superiority" (p. 8-9). In More Beautiful and More Terrible, Perry (2011) discussed the ways social practices are, "shaped by how an institution is raced and how raced institutions shape the raced lives of individuals" (p. 95). And, she also states that while racism may have material impacts, it also has "civic, emotional, perceptual, philosophical" impacts in other contexts (p. 9).

Over time, whites from various stations of society have ideologically bought into a social system of subordination that also performs an economic function and is maintained through institutions acting under the auspices of a racial hierarchy. These social norms, such as referring to black men as boys and black women as girls during the Jim Crow era, allowed all whites in society regardless of economic class to socially benefit from black subjugation. DuBois explains this point in Black Reconstruction (1992), "It must be remembered that the white group of laborers, while they received a low wage, were compensated in part by a sort of public and psychological wage" (p. 700).

Both the concept of black inferiority found in legal institutions and the cultural practices of inequality identify two distinct dimensions of racism: ideological and 
structural. Without acknowledging these interrelated and mutually supportive dimensions of racism, solutions are missed that address both aspects of race. Current carceral state literature often fails to parse through these two aspects of race and racism to understand them in a nuanced way. There are racial ideas held by individual actors that must be rooted out, and there are racialized practices embedded in institutions that can be carried out regardless of the inclinations of individual actors, what I call discriminatory design.

Ideology normalizes a racial hierarchy and helps generate racially disparate outcomes by individual actors acting on racial frames and narratives. Racial structures encompass political institutions and the economy, and their shaping of life experiences, here is where the racial hierarchy is maintained through material outcomes and a systematically unequal distribution of resources and power. Bonilla-Silva (2014) identifies this distinction by defining racial ideology and racial structure in his recent work on colorblind racism. Racial ideology is comprised of, "Frames or set paths for interpreting information. These paths operate as cul-de-sacs because after people filter issues through them, they explain racial phenomena following a predictable route" (p. 74). For Bonilla-Silva (2014), racial structures are the, "Totality of social relations and practices that reinforce white privilege... the task of analysts interested in studying racial structures is to uncover the particular social, economic, political, social control, and ideological mechanisms responsible for the reproduction of racial privilege in a society" (p. 9). I think of racial structures slightly different, I view it as the hierarchical racial organization embedded in the political economy that are replicated and reproduce racial inequality. 


\section{The Subjugation of Black Bodies for Profit}

Finally, the use of the carceral state to control and manage black labor, and to generate profits for the state and private industry, is a key concept that is under-addressed in contemporary literature regarding the carceral state. DuBois' Souls of Black Folk (1903) and Black Reconstruction (1935) are two works that adequately address this historical connection in detail. Writing in 1935, DuBois reminds us, "It must be remembered and never forgotten that the civil war in the South which overthrew Reconstruction was a determined effort to reduce black labor as nearly as possible to a condition of unlimited exploitation and build a new class of capitalists on this foundation" (p. 670). He also writes, "Above all crime was used in the South as a source of income for the state... In no part of the modern world has there been so open and conscious a traffic in crime [for] deliberate social degradation and private profit as in the South since slavery" (p. 698).

Here, we see the profitable imperatives attached to the carceral state's subjugation of African Americans, arising in tandem with a new economic order. These economic imperatives continue to exist. Examples include practices such as civil forfeiture programs dubbed "policing for profit," the Ferguson DOJ report that revealed the use of the carceral state as a means of generating city revenue, the use of grossly undercompensated labor for public works projects and private industry by state prisons and local jails, and the cash bail industry that predicates liberty on the ability to pay.

\section{Conclusion}


This chapter reviewed the literature on race and the carceral state and neoliberalism and the carceral state to illuminate gaps in our understanding of mass criminalization. It then, made an argument as to why neoliberalism and colorblind racism are interconnected and that the new racial structure of colorblind racism goes hand in hand with the neoliberal configuration of the political economy. Lastly, this chapter sought to illustrate why the disproportionate impact of the carceral state results from discriminatory design and highlighted three ways the carceral state has remained constant vis-à-vis the black American citizenship experience over time. The raciallydisproportionate impact of the carceral state, however, must not distract us from the unequal operation of the political economy and the hyperpunitive turn of neoliberalism that has impacted poor people across the racial spectrum. 


\title{
CHAPTER THREE: EXPLORING IMPACTS, CITIZENSHIP, \& THE CARCERAL STATE
}

\author{
"Whose streets? Our streets." - A chant from Ferguson, Missouri organizers
}

Understanding the impact of the carceral state on citizenship is another critical conversation in academic circles. Considering how the hyperpunitive carceral state shapes and influences citizenship, and how it is substantively experienced in daily life based on where one lives in the city, is instructive on the health of democracy. When the carceral state is the focal point of analysis, we are able to see the impact of the punishment and surveillance capacities of the state on local residents and communities.

Further refining the inquiry into the city space lends itself to understanding local democracy and is informative on forms of urban governance in the neoliberal era. We are able to see how carceral state institutions are also influenced and shaped by neoliberalism, and their impact on citizenship in the city. Guarnizo (2012) explains, "When analyzing citizenship, one of the first questions to ask is to what sociopolitical space does citizenship refer? More precisely, in what sociopolitical spaces are specific citizenship rights and duties actually applicable, achievable, redeemable, and enforceable" (p. 8). 
For Gottschalk (2015), the carceral state functions to leave those caught within its grip in a space short of full citizenship. In Caught (2015) she explains, "The carceral state has been radically remaking conceptions of citizenship as it creates a large and permanent group of political, economic, and social outcasts" (p. 2). In his work, Wacquant (2002, 2005) invoked civic death, a triumvirate of consequences arising from a felony conviction and prison incarceration. In 2002 he wrote, "Just as bondage effected the 'social death' of imported African captives and their descendants on American soil, mass incarceration also induces the civic death of those it ensnares by extruding them from the social compact" (p. 58).

Wacquant identifies a "threefold movement of exclusionary closure" where "prisoners are denied access to valued cultural capital: just as university credentials are becoming a prerequisite for employment in the (semi)protected sector of the labor market, inmates have been expelled from higher education.... Prisoners are systematically excluded from social redistribution and public aid in an age when work insecurity makes access to such programmes more vital than ever... [And] Convicts are banned from political participation via 'criminal disenfranchisement' practiced on a scale and with a vigour unimagined in any other country" (p. 57-58).

Studying the political implications of the carceral state is a relatively new endeavor in academia and the field of political science. Much of the political science literature devoted to imprisonment focuses on disenfranchisement and the loss of the right to vote among felons. Two more recent works analyze the political implications of the carceral state and mass incarceration for citizenship and democracy. These are Trading Democracy for Justice by Burch (2013) and Arresting Citizenship by Lerman 
and Weaver (2014). Both pieces of scholarship contend the criminal justice system impedes political participation and shapes how citizens perceive the state and democracy. According to Lerman and Weaver (2014), the growth of the carceral state created a new social division and a class of political marginalization; one they term the "custodial class." In researching the lives of custodial citizens, Lerman and Weaver (2014) explored how carceral state contact shapes everyday lived experiences of citizenship and influences people's perceptions and experiences of the state and their role within a democratic society. These scholars visited three cities: Charlottesville, New Orleans, and Trenton, and spoke to eighty individuals with different degrees of carceral state contact. The interviewees in Charlottesville had no prior experience with being stopped, arrested, convicted, or incarcerated. Lerman and Weaver (2014) concluded, "Custodial populations are systematically different from noncustodial citizens. They are much more likely to be poor, less education, more unstable in family relationships, and more likely to be a member of a racial or ethnic minority" (p. 2).

They also found custodial citizens have a distinct worldview where interaction with criminal justice authorities constitutes the most frequent government engagement and the government is perceived as actively doing harm. They explain that custodial citizens are, "objectified and dependent, rather than equal participants... And rather than communicating that they are worthy and valued citizens, their experiences with criminal justice teach them that they have little voice and mark them as outside consideration" (p. 121).

Alternatively, Burch (2013) takes a neighborhood level view of the political implications of the criminal justice system. Burch primarily conducted quantitative 
analysis to argue that the criminal justice system sends signals to democratic citizens and influences whether they "feel acknowledged, respected, and included as equal members of the polity" (p. 15). Burch's research sought to determine how increased criminal justice contact, concentrated at the neighborhood level, impeded the desire and ability of citizens to act in the political world measured empirically. Burch operationalized political participation as voter turnout and found residents of high-imprisonment neighborhoods were less likely to vote. Further, while residents of those neighborhoods had less interpersonal trust, they were not significantly less likely to feel efficacy or trust in the police in comparison to other low-incarceration neighborhoods. Burch explains, "Having a high concentration of convicted offenders in a neighborhood means having a high number of individuals who share a problematic relationship in one space.... Offenders are physically and psychically excluded from social, economic, and political life through the actions of the state (p. 31).

The present inquiry is situated in this strain of political science literature seeking to understand the implications of the growing carceral state for democracy and citizenship, with a specific focus on the urban, neighborhood level. Therefore, this research project provides a spatial and theoretical reframing of the current literature. Like Lerman and Weaver, the analysis of citizenship presented here has sociological elements. As Evelyn Nakamo Glenn (2011) explains, “sociology’s special strength may lie in its focus on the social processes by which citizenship and its boundaries are formed. In particular, sociologists can highlight how citizenship is constructed through face-to-face interactions and through place-specific practices that occur within larger structural contexts" (p. 2). I take precisely this cue from sociology in attempting to understand how 
the carceral state impacts the substance of citizenship, and the analytical framework I propose for investigating citizenship is described later in this chapter.

The analytical endeavor presented here not only provides a reframing that considers both race and the political economy in relationship to the carceral state, it also maintains a specific emphasis on city life. The focus on urban neighborhoods and city life is another contribution to existing literature because it considers local government institutions that primarily administer carceral state functions. In Caught, Gottschalk (2015) called for a "more fine-grained understanding of the specific political, economic, and institutional factors that shape penal policy" (p. 10). This research project seeks to answer that call through studying the impact of concentrated, local carceral state interventions in two poor urban neighborhoods in the city of Louisville, Kentucky. Lerman and Weaver (2014) found significant commonalities between the outlooks of custodial citizens with direct carceral contact and individuals who experience systematic disadvantage but contend that the worldviews of custodial citizens are distinct in degree and kind. I diverge on this point from these scholars and build on their finding that the carceral state influence on substantive citizenship is grounded in a combination of geography, race, and class. Space is a critical consideration in seeking to understand the carceral state, because when it is concentrated in communities, it can generate indirect impacts for individuals who may not themselves be ensnared by the criminal justice system in one form or another. This study reveals that with or without carceral state contact those who experience systemic disadvantage and those who have carceral contact maintain quite similar worldviews. 
When space is considered as part of the analysis, the ubiquity of carceral state interventions makes these two groups indistinguishable. My contention is that custodial citizenship can be generated by where one lives in the city, with or without direct carceral state contact. And further, that the nature of neoliberal local governance is directly implicated in creating a custodial citizenship for the poor. Below, I discuss in greater depth why this research project is explicitly urban in orientation before turning to the four-part frame of citizenship in the city.

\section{The Importance of the Urban Space}

The term "urban" identifies a space where social relations and the political economy are actualized in a densely populated context. Directing this study toward the city space, and specifically urban neighborhoods, is important for a few reasons. It highlights the characteristics and impact of local state interventions, specifically the carceral state, and their role in substantively shaping citizenship in communities of concentrated poverty. The inquiry also allows for a consideration of neoliberal policies in urban institutions, by learning about resident encounters with the carceral state and other local government offices. Lastly, the role of cities as economic engines, within the context of spatially expressed inequality, lends itself to considering how the political economy, and an unequal economic order, impacts people on the ground along lines of race and class.

For Wirth (1938) "city life" maintains particular characteristics that mark the city as a distinctive mode of social life, "we are exposed to glaring contrasts between splendor 
and squalor, between riches and poverty, intelligence and ignorance, order and chaos" ( $\mathrm{p}$. 14-15). As the epicenters of the new global economy and post-industrial modes of production, cities become key sites of study. According to Sassen (1996), examining cities allows the researcher to see a "multiplicity of economies and work cultures in which the global information economy is embedded" (p. 100). The complex global economy, "shapes local democratic institutions, practices, and behavior. Economic stress often leads to social conflict and this is played out in political battles, voting alliances and struggles over jobs and resources" (Savitch, Dupont, \& Drumm, 2000, p. 370).

Writing on urban violence from a European perspective, Body-Gendrot (2011) explains that the debate is marked by economic-related anxieties that displace "more urgent questionings on new forms of inequality and social marginalization that are appearing in cities" (p.22). Body-Gendrot connects the "eroding buffer role of the social welfare state" to the "local arena... as the site impacted by the negative consequences of economic restructuring and rapid social mutations" (p. 22). A polarized post-industrial economy largely fueled by technological shifts and neoliberal policies that reinforce inequality are observable in racially- and economically-segregated, hyper-policed American cities.

The post-industrial economy has shifted the nature of work, and as a result, changed social relationships and the built environment of urban centers (Savitch, 1988; Sassen, 2001; Sassen, 2012). Inner-city manufacturing jobs employing low-skilled workers lost through deindustrialization have been replaced by retail and service industry jobs with lower wages, less stability, and fewer benefits and worker protections (Wilson, 2009; Denton \& Massey, 1993; Dreier, Mollenkopf, \& Swanstrom, 2004). Job growth 
has occurred primarily in the suburbs creating a job-spatial mismatch between employment opportunities and inner-city residents (Wilson, 2012; Wilson, 2009). These changes in employment opportunities, combined with an outflow of middle and upper class residents to the suburbs, served to intensify concentrated poverty and its effects in inner city neighborhoods (Wilson, 2012; Wilson, 2009).

Focusing on the urban is important, because it is a space that reflects the most profound inequalities of the neoliberal postindustrial economy and its racial dynamics. The undermining of the social safety net and welfare reform have led to high levels of inequality and the most sizeable group of the poor and unemployed in U.S. history (Alexander, 2010). Dreier, Mollenkopf, and Swanstrom (2004), described how where we live reflects growing economic inequality. They write, "Economic classes are becoming more distant and separate from each other as the rich increasingly live with other rich people and the poor live with other poor people" (3).

For Wacquant (1999), the city is the site where structural economic logics and social relationships of power that fuel marginality are spatialized. Wacquant (1999) describes marginalized urban neighborhoods experiencing mass incarceration and concentrated poverty as "entrenched quarters of misery... repositories for all the urban ills of the age, places to be shunned, feared and deprecated" (p. 1644). Both the state and social relations play a role in how the post-industrial economy unfolds in space. According to Theodore and Brenner (2002), "the geographies of state institutions and policies are closely intertwined with evolving processes of uneven development: states provide a relatively stable regulatory landscape within which capital's locational dynamics are articulated" (p. 356). 
Studying how the carceral state shapes substantive citizenship at the urban scale aids in understanding how the carceral state can function as a tool of neoliberal urban governance. As Samara (2012) writes, "urban areas are currently dominated by forms of governance... in which market principles infuse not only economic relations but also social and political relations. They form a dynamic infrastructure of urban governance that leaves some legal residents... effectively outside of the de facto polity through which urban space is produced" (p. 43). For the residents included in the present study, the primary mode of local governance for the poor occurs through local carceral state interventions that functionally alter substantive citizenship through punitive and surveilling interactions.

In disadvantaged communities the capacity of the state to surveil and punish is determinative of the life trajectories of an overwhelming number of residents. As Clear (2007) noted, "Policy choices have had distinct implications for the way prison populations reflect a concentrated experience among certain subgroups in the US. Population- in particular young black men from impoverished places” (p. 49). In a study of Chicago, "from 2005 to 2009, there were 851 city blocks that each represented $\$ 1$ million in prison sentence costs." These expenditures were primarily concentrated, "on residents from low-income, segregated, and predominately black communities" (Bliss, 2015). The practice of over-policing poor communities, often predominated by people of color, is generated not solely by the "War on Drugs" but also through order-maintenance, broken windows, and aggressive stop and frisk style policing.

The research of Sampson and Loeffler (2010) showed geographies of concentrated economic and racial segregation maintain the strongest relationship with the 
carceral state. Sampson (2012) also made claims about neighborhoods in his work Great American City, claiming that disadvantaged communities experience systemic and durable patterns in replicating inequalities. He writes, "A durable spatial logic organizes or mediates much of social life, with neighborhoods and local communities as a key component" (p. 21). The expansive growth of the carceral state since the 1970s has functioned to contribute to the durability of inequality in hypersegregated communities. Considering the political economy of place illuminates the way the carceral state becomes a tool of governance for the urban poor and its implications for democracy. Therefore space, and specifically the urban space, plays a central role in the present analysis of the impact of the carceral state on citizenship.

\section{Citizenship in the City: An Analytical Framework}

Citizenship in the city is a term meant to invoke a sense of belonging in a particular space, in this case the urban space. The phrase refers to the ways people's daily lives as citizens in the urban space unfold along four frames: social, political, economic, and in terms of what I call mobility. There exist gradations in substantive citizenship across different city neighborhoods depending on the racial and economic demographics

of the community. This chapter describes the growing inequality, increased isolation, and disproportionate hypersegregation of people of color and poor people in urban centers. I position these outcomes that unfold unequally in space, squarely within a postindustrial, neoliberal political economy, and think about how political processes and economic 
changes have shaped and influenced citizenship, specifically through the actions of carceral state.

My conceptualization of city citizenship is multidimensional and considers the substantive economic, political, social, and mobility lives of urban residents. City citizenship, as I theorize it, is a spatial concept that identifies the different ways individuals and communities participate in the everyday life of the city. The four dimensions help categorize repetitious experiences taking place in the daily urban fabric between community members, their neighborhood, and the state. Citizenship in the city is a frame centered on unpacking the substantive content of citizenship in a systematic and organized way.

The experiences of people economically, socially, politically, and terms of what they can access, what I call mobility, is profoundly shaped by their location in the city. As this chapter explains in greater detail, citizenship is a tool of governance because the state may bestow or exclude residents from certain rights and privileges, impacting the substance of their lives. The state may also implement a system of incentives and punishments with profound citizenship effects. In this chapter I hope to also illuminate how citizenship contributes to racial hierarchies, and this is a key concept when thinking about racism as a structuring force that shapes outcomes in society.

Hierarchies and relationships of power are maintained and replicated by state practices that deny access to resources, create limitations on voice in democratic institutions, or by simply denying citizen input in government institutions altogether. The different dimensions of citizenship in the city that will be described in detail later in this chapter, are all elements in maintaining a hierarchical political economy that keeps poor 
people and people of color on the bottom. The state creates limitations on citizenship through systematic and varied practices that uphold unequal relationships of power economically, socially, politically, and in terms of access or what I refer to as mobility.

Citizenship is a multifaceted concept theorized and written about for centuries. The most commonly accepted notion of citizenship is that it is a series of duties and rights placed upon and granted to individuals by the state as part of their membership in a political community (Marshall, 1950; Faulks, 2000). As Marshall (1950) explained, "Citizenship is a status bestowed on those who are full members of a community. All who possess the status are equal with respect to the rights and duties with which the status is endowed" (p. 28). Turner (1993) describes citizenship as, "a set of practices (juridical, political, economic and cultural) which defines a person as a competent member of society, and which as a consequence shape the flow of resources to persons and groups" (p.2). Therefore, citizenship, in its formal, theoretical sense, indicates an inclusionary status where the state treats an individual equally to their counterparts who are also considered to be part of the same political community.

The substance of the citizenship, however, is historically-dependent and relational, shaped by the political institutions, and economic and social structures in which it is practiced and reproduced in space (Brodie 2000, Rose 2000). While people may formally belong to a political community, the substance of their citizenship experiences may be varied because of their racial classification or class status. Consider, for example, the citizenship status of African-Americans during the era of Jim Crow. Granted national citizenship status through the $14^{\text {th }}$ Amendment, yet denied privileges 
and rights afforded to their white counterparts. As a tool of governance, citizenship provides access to societal rewards and opportunities (Guarnizo, 2012).

Brodie (2000) defines the content of citizenship as the relationship between the state, civil society and the individual, "resulting from ongoing political struggles embedded in a historical matrix of governance" (p. 11). Samara (2012) wrote that, various mechanisms of exclusion produce a "tiered citizenship, wherein the formal borders of citizenship expand even as access to power within those borders become more restricted" (p. 41). In neighborhoods of concentrated poverty where carceral state contact occurs with regularity, this study asks how persistent carceral state interactions limit resident participation in broader city life- socially, economically, politically, and in their access to public space.

Are resident lives impacted to the degree of becoming something less than full citizens due to their experiences with hyperpolicing and surveillance by local government in their community? Space is always relevant to a discussion of citizenship, because it drives us to ask questions about rights and duties for whom and where, and what they may look like substantively in a particular spatial context. Dagger (2000) explains, "The city is more accessible to its residents, more closely tied to their interests, and more likely to promote the sense of community that is usually associated with citizenship" (p. 25).

It is important to clearly define the primary theoretical frame of analysis for this study and to describe in detail what I mean by "citizenship in the city." City citizenship is a conceptual framework substantively constituted by the inclusion or exclusion of residents from the economic, political, social, and spatial life of the city. Citizenship in the city in practice arises from the interplay between and various arrangements of state 
processes, the political economy, and social relations among those living in the city. It is intended to capture "substantive citizenship,"

The concept of citizenship in the city is heavily influenced by Lefebvre's (1967) idea of the right to the city. The right to the city references a spatial critique of modes of capitalist production and politics, and in turn generates normative directives for the claims of city residents. Purcell (2013) elaborates, "Most agree that it is the everyday experience of inhabiting the city that entitles one to a right to the city, rather than one's nation-state citizenship. As a result, most also emphasize the importance of the use value of urban space over its exchange value.... And so in almost all its forms the right to the city is understood to be a struggle to augment the rights of urban inhabitants against the property rights of owners" (p. 142). Further, Purcell (2013) articulated Lefebvre's concept as, "An open and evolving project... that comes to understand itself as more than anything a democratic project, as a struggle by people to shake off the control of capital and the state in order to manage their affairs for themselves" (p. 145). For me, in its most basic sense, Lefebvre's (1967) concept makes democracy, i.e., governance by the people in the space where they live, the ultimate guiding principle for urban societies.

My reading of Lefebvre (1967) is also one that radically re-imagines citizenship rights as the inclusion of residents in governing institutions, the economic and social life of the city, and further, city space as having value for its social value and not solely its exchange value in the market. The right to the city is antithetical to what Brodie identifies as, "The neoliberal redefinition of community from shared space to individual attributes... [Neoliberalism] recasts the individual, the citizen and ultimately, the community in abstract and decontextualized language of neo-classical economics and 
liberalism. Government policy turns from the concept of collective well-being and community-building to the problems of particular 'communities' that require regulation, surveillance and discipline" (p. 123).

For Lefebvre (1967), the right to the city included a right for citizens to have access to and participate in the economic, social, and political bodies of urban centers. Kuymulu (2013) characterizes the right as access to resources and a "radical transformation of material processes." Harvey (2012) claimed the right to the city entails, "some kind of shaping power over the processes of urbanization, over the ways in which our cities are made and re-made and to do so in a fundamental and radical way" (p. 5). My own conceptualization of citizenship in the city is constructed as a matrix of rights, privileges, and access to participate in city life, similar what Lefebvre (1967) calls the "oeuvre," of the city, a work in which all its citizens participate. Citizenship in the city is also directed toward addressing the critical disconnect of substantive citizenship where members of the urban population may possess formal, national citizenship, yet still be denied equal access to opportunities and resources in the city where they reside.

Holston and Appadurai (1996) highlight the importance of substantive citizenship when they write, "the array of civil, political, socio-economic, and cultural rights people possess and exercise, much of the turmoil of citizenship derives from the following problem: although in theory full access to rights depends on membership in the nationstate, it is increasingly neither a necessary or sufficient condition for substantive citizenship. That it is not sufficient is obvious for many poor citizens who have formal membership in the state but who are excluded in fact or law from enjoying the rights of citizenship" (p. 190). Marshall (1950) highlighted the tension between the inequality 
embedded in the economic order and citizenship rights, as an example he noted the inability of someone to defend their civil rights in court without the financial access to a competent attorney.

The urban neighborhood is a particularly important frame to study citizenship because this is the locale where, "citizens live their lives and wage their struggles for livelihood and dignity" (Purcell, 2012, p. 191). Neighborhoods are where citizens confront the state and inequalities in substantive citizenship are most pronounced due to the economic and racial segregation persisting in American cities. The material lives of poor, urban residents living in concentrated poverty is vastly and markedly different from their counterparts living in affluent suburban enclaves, and residents in these disparate communities encounter the state on different terms as well. My inquiry into substantive citizenship is grounded in a study of racially and economically isolated urban neighborhoods fraught with carceral state contact to highlight how the state helps maintain hierarchies and gradations in citizenship status. I propose to investigate two communities of concentrated poverty in one city by interviewing the residents about their experiences in the community and contact with the carceral state.

The neighborhoods of study were chosen after compiling census tract data for the most racially homogenous census tracts with the highest concentrations of poverty. Census tracts were used as proxy for neighborhoods and the two communities were chosen based on their racial demographics, their class demographics, and their location in the urban city center. Therefore, the resulting two neighborhoods for this study are a predominately black neighborhood with high rates of poverty as measured by household income and the percentage of residents below the poverty line, and a predominately white 
neighborhood also with high rates of poverty. The methodology is laid out in further detail in Chapter 4 of this dissertation.

Four components compromise my conceptualization of city citizenship for this study: social, political, economic, and mobility. I now turn to an explanation of the four dimensions of city citizenship that constitute the analytical frame for this research project, that were also used to guide the development of the interview instrument for the project. The overall goal of the following discussion is to illustrate each "site" where I am looking to locate inclusion or exclusion in the life of the city. The interview chapters for each neighborhood use resident interviews to illustrate how the carceral state impacts the substance of citizenship in each area. In what follows, a great deal of time is spent on social citizenship, and here is where I continue to discuss the importance of understanding the structural and ideological dimensions of race. I then move through each of the remaining frames to help highlight how they impact substantive citizenship overall.

\section{Social Citizenship}

In T.H. Marshall's 1950 meditation on citizenship presented in his Cambridge Lectures, he poses the question, "Is it true that basic equality, when enriched and embodied in the formal rights of citizenship, is consistent with the inequalities of social class?" (p.9). In noting the twentieth century tension between citizenship and the class system, Marshall wrote, "social class of the second type is not so much an institution in its own right as a by-product of other institutions... class differences... emerge from the 
interplay of a variety of factors related to the institutions of property and education and the structure of the national economy" (p. 31). As defined by Marshall (1950) social class, "Is a system of inequality. And it too, like citizenship, can be based on a set of ideals, beliefs, and values" (p. 29).

When I invoke the notion of social citizenship within the framework of citizenship in the city, I am referring to the concept of social class, but with an emphasis on the ideas, beliefs, and values tied to a specific social class. In this articulation of social citizenship, not to be confused with Marshall (1950), I consider the social meaning attached to groups and social classes, and their position in a socio-political economic hierarchy that justifies inequality. For the purposes of this research social citizenship also refers to the shared socio-cultural meaning attached to space and the class of people that inhabit it. This dimension of citizenship in the city considers how the race and class compositions of communities influence the storytelling about it and its residents. In my view of the social dimension of citizenship is grounded in the countless ways individuals create and reproduce social meaning in the spaces in which they interact tied to social class (Guarnizo, 2012).

Space is a key element of social citizenship because it encompasses the narratives we generate about neighborhoods and the people who inhabit them, and neighborhoods are highly dictated by social class. In my framing social citizenship involves shared understandings of which individuals and groups, "can properly live and work," in particular spaces (Painter \& Philo, 1995, p. 113). According to Painter \& Philo (1995), "socio-cultural relations are intrinsic to the political relationship between citizenship and space... [the] social cultural form of citizenship [is] wrapped up in questions about who 
is accepted as a worthy, valuable, responsible member of [the] everyday community of living and working" (p. 113-115).

But, social citizenship is not just about ideas, it is also about the ways our conceptualizations of race, class, and space, influence the state response to social groups, and how opportunities and rewards flow to them as a result. As mentioned previously, some communities come to be defined by the state as in need of regulation, surveillance, and discipline and this is part and parcel of social citizenship. An analysis of social citizenship in the American city is simply incomplete without an exploration of race. Bonilla-Silva (2014) refers to racial ideology as the racial stories and frames used to explain and or justify the racial status quo of white supremacy and black inferiority. These ideas about social class are instrumental in naturalizing a race and class hierarchy that can be sustained by state action, particularly in the realm of citizenship.

Race ideologically, is about shared ideas and these shared ideas justify a racial logic of inequality embedded in the economic hierarchy of American society, supported by government institutions, and particularly the carceral state (in fact, historically and always involving the carceral state for black people). The shared understandings of race, such as black criminality, invoked and understood even by black interviewees who participated in this study, support configurations of racial inequality as natural and normal. Ideologically, race masks the ways the state maintains structural inequality through interventions and impingements on the substance of citizenship.

Returning to Marshall (1950), social class and its inherent inequalities are the byproduct of institutions and the economy, and there are specific values and beliefs created about different social classes. In the same way the carceral state is an institution 
that plays a role in producing and reproducing ideas about race, so are the neighborhoods where people live and work. Legal scholar Martha Mahoney (1995) helps to elaborate my point when she writes: "[S]egregation is the product of notions of black inferiority and white superiority, manifested geographically through the exclusion of blacks from more privileged white neighborhoods and the concentration of blacks into subordinated neighborhoods stigmatized by both race and poverty... In turn the segregated world we inhabit comes to define race for its inhabitants" (p. 1659).

In this way, race takes on a natural, normal appearance that masks structural and economic and political processes, because the group of people being disenfranchised is understood as a deviant social class. I return to Mahoney's (1950) discussions of neighborhoods again because she highlights the importance of grappling with both racial ideology and racial structures, in addition to showing the political and economic processes that a solely racial frame hides from view. She writes, "The structural problems that residential segregation brings- distance, inconvenience, lower tax base, more concentrated poverty- continue to be reproduced because of their role in reinforcing and reproducing the social construction of race" (p. 1675).

Understanding how citizens make sense of their neighborhood within the broader context of city life and the social meaning they attach to it is a significant part of this study. It is within the frame of social citizenship we are able to see how urban residents think about race and class, and how it is connected to the political and economic interventions that shape their lives as citizens of the city. I am seeking to understand how the carceral state and the level and type of its engagement in the neighborhood influences how people understand their social position in the city as a result of where they live. Do 
they feel valued as residents? Do they believe the racial or class composition of their community informs the way in which the carceral state is deployed in their community? Do they believe their neighborhood is treated differently from other communities and what signals are being sent that communicates this to them? These are all questions bound up in the social frame of city citizenship.

\section{Economic citizenship}

What I call the economic dimension of citizenship is precisely T.H. Marshall's notion of social citizenship. For Marshall (1950), in order for civil and political rights to have significance, the state must also guarantee social rights. It is the "right to a modicum of economic welfare and security... to live the life of a civilized being according to the standards prevailing in society" (p. 8). This is a key point, because neoliberal state restructuring rolls-back social welfare or decentralizes and privatizes social welfare benefits. In the neoliberal age the citizen is viewed as entrepreneurial, and citizenship benefits are earned through participation in the free market, and not guaranteed by the state. A neoliberal logic rejects the social welfare role of the state.

Judith Shklar (1991) wrote, "The individual American citizen is in fact a member of two interlocking public orders, one egalitarian, the other entirely unequal" (p. 64). Again, the tension between the concept of equality in formal citizenship and the unequal economic order are being highlighted. "One of the most powerful mechanisms of control and disciplining," according to Guarnizo (2012), are limitations imposed on "access to 
local economic opportunities" (p. 18). Here, is where I think of the impact of the carceral state on economic citizenship in the city.

While the literature recounts the impact of felony convictions on future wage earnings and employment opportunities, there are a number of other economic consequences associated with lower-level carceral state contact that are worthy of study. Economic opportunity is already sparse in some neighborhoods with high rates of unemployment, precarious low-wage temporary workers, and a preponderance of lowincome households. The carceral state impacts the economic citizenship of residents and impedes their ability to access sufficient economic resources. One known way the carceral state accomplishes this is through fines and fees for low-level offenses and the predominance of cash bail required to secure an individual's release following arrest. Institutions such as the Department of Justice and legal think tanks acknowledge these two phenomena as poverty enhancers. In recent years a series of law suits have cropped up across the country challenging the "criminalization of poverty." This study, therefore, asks residents to consider the economic impact of the carceral state on their lives in a variety of ways.

\section{Political Citizenship}

This study also asks residents to think about their political power and influence in relationship to their neighborhood and if the carceral state shapes their own perceived political standing. Political citizenship includes and moves beyond the right to vote and is considered more broadly as voice and decision-making power in democratic institutions 
and also, community engagement by residents. Who governs community institutions and the loci of decision-making power are integral to political citizenship. Lerman and Weaver (2014) described at length the way different criminal justice institutions including police and prosecutor's offices function anti-democratically. These institutions from jail to police departments to district attorney offices are all administered locally, most often under the auspices of city government. Understanding how people's perceptions of and access to political power are shaped by the carceral state is another dimension of this study's charge to understand the influence of the carceral state practices on citizenship in the city. I ask the question, do people in high incarceration communities feel that they play an important role in the democratic processes of the city and have voice in the institutions impacting their lives?

In exploring political citizenship, I am also interested in learning if carceral state contact at the community level impacts political participation. In the state of Kentucky felons are prohibited from voting without a petition to the governor to have their rights restored. However, I want to move the notion of political participation beyond the scope of voting to a broader discussion of other forms of political engagement including attending community meetings and volunteering with neighbors to improve the community. These are important dimensions of political citizenship because they help build community and can further help develop the unified voice of citizens to spur policy action. In this study, I am interested in understanding why residents may or may not participate in neighborhood life politically and if the carceral state plays a role in diminishing participation. Also, the study considers how residents define, exercise, and 
articulate their own political power, particularly as it relates to how local government engages their neighborhood and its community members.

Mobility

The final dimension of citizenship in the city is a concept that has been largely excluded from the most common triumvirate of articulations of citizenship and mass incarceration. For me, mobility is the ability to move freely throughout the city and to access public space and accommodations in the metropolis. Part of citizenship is belonging to a particular community, and when one's mobility is impeded through state authorities- whether through stop and frisk or being made to feel unwelcome via heightened surveillance- this indicates to them that they are either not part of the community or are a deviant member of that community.

Mobility strongly connects to Lefebvre's (1967) notion of the right to the city because it is reflective of the right to access public space through a full and complete usage of it through work or play. Expanding on Lefebvre's (1967) theory, in his work The Right to the City, Mitchell (2003) explored the proliferation of city ordinances functionally criminalizing homelessness to remove them from the public's view. Mobility involves the ability of city residents to move through their community with limited carceral state interaction. It also encompasses the ability to freely and equally access public accommodations and amenities throughout the city.

Mobility is highly raced in American society as well, and I think of it in relationship to the historical pursuit of the social control of African-Americans. There 
have been numerous incidents garnering national attention related to accessing public space that illustrate my point. Race has both historically and in the present been used as proxy to exclude from public space. Most recently, two African American men were arrested in a Philadelphia Starbucks while waiting on a colleague prompting public outcry causing the coffee franchise to shut it stores down to hold implicit bias training for its employees (Hanna, Sgueglia, \& Simon, 2018). In McKinney, Texas, officers were called to a public pool when a large number of African-Americans were present, and the same happened at a BBQ in a public park in Oakland (Capehart, 2015; Herreria, 2018). Both swimming pools and public parks were contested public spaces during the era of Jim Crow segregation. Limitations on equal access to space and public accommodations are an element of the African American citizenship experience with a lengthy history dating back to enslavement when groups of black people were legally prohibited from gathering in public.

\section{Conclusion}

Wacquant (2005) described the outcome of a felony conviction as civic death, a triumvirate of exclusions from social redistribution, cultural capital, and political participation. In this research the framing of civic death departs from the predominate conceptualization in the literature in a few ways. First, civic death does not require a felony conviction and mass criminalization concentrated in space has its own unique citizenship effects that are created through direct and indirect carceral state contact. Further, if we accept that social, political, and economic citizenship are integral to the full 
practice of citizenship, then we can say that there are individuals living in economically depressed, isolated urban communities who already experience some modicum of civic death, even without carceral state contact. The carceral state represents one element in a matrix of barriers to the equality of citizenship in the city. The persistence of carceral state contacts concentrated in a community demonstrates how state interventions function to limit citizenship through compounding the impacts of poverty and making it more difficult to escape its grip.

This inquiry seeks to gain a broader view of the quantity and type of carceral state experiences had by residents beyond felony convictions. The research project pursues a comprehensive understanding of the ways the local government engages and governs urban citizens in the context of an economically and racially polarized city. The limitations created by the state within each of these four dimensions of citizenship reinforces and maintains a hierarchical organization that keeps the poor, who are disproportionately people of color, on the bottom. In each of these facets of substantive citizenship it is precisely government intervention that exacerbates the already precarious situations of those who experience the highly unequal post-industrial economy.

This chapter combined with the previous two have outlined the research questions for this study and identified gaps in the literature the questions attempt to address. Here, I attempted to present an analytical frame for exploring substantive citizenship in the urban space by considering its social, economic, political, and mobility dimensions. In what follows, I identify the methodological approach to the study and detail the research design and the case study used for the research project. The crux of the findings for this dissertation are gleaned from identifying themes in interviews with people from two 
neighborhoods of concentrated poverty- one predominately white and the other predominately black. The findings are organized around the four-part frame of citizenship in the city in Chapters 5 and 6 that discuss the Russell and Portland neighborhoods respectively. 


\section{CHAPTER FOUR: THE CASE STUDY \& METHODOLOGY}

"The technique of imagining oneself black and poor in some hypothetical world is less effective than studying the actual experience of black poverty and listening to those who have done so" - Mari Matsuda

Mari Matsuda (1987) wrote, “Those who have experienced discrimination speak with a special voice to which we should listen" (p. 324). Taking a cue from her concept of "voices from the bottom," I find the best way to understand hard to pin down and contested theoretical concepts like citizenship, neoliberalism, and race are through a finetuned analysis of qualitative data that can help describe the "on the ground" impacts of the carceral state. Community members can best describe, from their own unique perspective, the daily interactions between local government, the neighborhood space, and other residents that constitute the substance of citizenship. Qualitative data provides a narrative structure and helps explain social, political, economic, and political processes that quantitative statistics identify but are unable to adequately unpack and describe in a way that brings nuance to their understanding.

The daily repetitions of interactions between people and the built environment of their community, with other residents, and government institutions constitute the substance of citizenship. To investigate the research questions centered on understanding the carceral state's impact on poor urban communities, I undertake a case study of two neighborhoods in Louisville, Kentucky. The significant data for this research is interviews with resident 
about their perceptions of their community, the carceral state, local government, and their citizenship experiences.

As mentioned in the introduction, the urban space plays a central role in this research in a way that it does not for Lerman and Weaver (2014). These scholars found significant commonalities between the outlooks of custodial citizens with direct carceral contact and individuals who experience systematic disadvantage but, "suggest that the political orientation of custodial citizens are distinct in both degree and kind... custodial citizens, in contrast to others with whom we spoke, maintain a distinctive 'lifeworld"' (p. 25).

I diverge from their claim that custodial citizenship is different from systematic disadvantage by grounding my study in two high carceral state contact communities in one city. Concentrated carceral state contact that is commonly found in neighborhoods marked by systematic disadvantage, acts as a structuring force that exacerbates inequality and generates a custodial status for the entire community. The entire neighborhood is rendered suspicious and police presence is a constant in the communities included in this study. The deployment of the carceral state in the neighborhoods of study represents the most frequent form of government contact.

Lerman and Weaver (2014) conducted interviews in three different cities with individuals participating in felon re-entry programs and with one group of interviewees who had no previous criminal justice contact. Reentering felons have the deepest engagement with the carceral state but lower levels of contact, and even indirect contact can have citizenship impacts as well. My method is to interview neighborhood residents in two high arrest communities of concentrated poverty in one city. The interviewees in my study may or may not have had direct contact with the carceral state but all reside in a 
community where arrests are ubiquitous. Therefore, it tests Lerman and Weaver's (2014) claim that directly experiencing carceral state contact is a unique form of civic education that generates custodial citizenship.

I think of the carceral state as having community-wide effects when it is concentrated in a neighborhood, making space a central concern. I further hypothesize that the citizenship experiences of residents without their own direct contact are impacted and shaped indirectly by the pervasive presence of the carceral state as well. For example, through the contact of family members with the carceral state or through daily observations of police interactions in the community residents can become "custodial citizens" and share the same outlooks about the state as those who do have direct experience. In some communities, the carceral state constitutes one of the, if not the, primary form of urban governance.

Also of note is the difference between the levels of carceral state contact among study interviewees. By interviewing re-entering felons, Lerman and Weaver's (2014) study focuses on individuals who have experienced the highest levels of criminal justice punishment. There is much room to understand how lesser forms of carceral state contact- stop and frisk, receiving a citation and being assessed a fine, and brief jail stays due to arrest all have implications for the substantive citizenship of those who experience it. Therefore, the interviews and surveying of residents in this study are attuned to exploring the impacts of lower-levels of carceral state contact as well.

Another reason for the focus on the local is because cities are primarily responsible for the administration of the carceral state via police, local courts, and jails. As Alexis de Tocqueville (1969) wrote, "Local institutions are to liberty what primary schools are to 
science; they put it within people's reach" (p. 63). If one wants to understand how individuals experience citizenship and how the carceral state impacts it, the urban space is a key site for this endeavor. Additionally, as will be described in greater depth in this chapter, cities most profoundly reflect global economic shifts and the unequal spatialization of the postindustrial political economy, making urban spaces ripe for understanding how the state responds to capital and its people.

Neighborhoods present an important frame for studying the interconnections between race, class, and the carceral state because they are the space where macro political and economic developments become materialized and are experienced by citizens on the ground. Neighborhoods are where residents directly grapple with and confront development or disinvestment in the postindustrial economy. Urban communities are key sites of study because they influence what food people have access to, what kinds of social interactions they have with neighbors, the institutions and spaces where these exchanges take place, and what appendages of local government they encounter. The neighborhood effects of accessibility are particularly amplified when residents largely do not have a form of reliable transportation. This study is directed toward understanding citizenship in the city and as such it also becomes illustrative of urban governance strategies and how urban populations are managed by the state. It contemplates how city residents are encountering local government institutions- do they receive opportunities and rewards from city government interactions or is the state primarily encountered through mechanisms of surveillance and punishment?

Finally, urban neighborhoods are important sites for observing social and economic stratification, and particularly inequality. Since the 1970s, economic segregation at the 
neighborhood level is steadily increasing American urban centers (Cashin, 2014; Sampson, 2012; Wilson, 2009; Wilson 2012; Dreier, Mollenkopf, \& Swanstrom, 2004). The American public school system continues to be both racially and economically segregated and much of this institutionalized separation is attributable to housing patterns (Ong and Rickles, 2004; Stancil, 2018). Changes in macroeconomic conditions enhance the geographic intensity of poverty and inequality in areas already stratified by class and race (Sampson, 2012; Denton \& Massey, 1993). Exploring the carceral state's impact on these processes of inequality is an important endeavor because an inquiry into neighborhoods helps reveal how broad scale changes shape local citizenship in the city. Focusing on neighborhoods also illustrates how the carceral state is a tool of governance, particularly in poor neighborhoods of color. What follows next is a brief historical background of each of the neighborhoods included in this study and a review of the survey and arrest data collected in them both.

\section{The Case Study}

The case study method allows for a holistic view and deep-meaning investigation of real-life events (Yin, 2003). To study the impact of the carceral state on citizenship in the city I utilize a mixed-methods approach toward two neighborhoods of concentrated poverty and disadvantage. The neighborhoods are located in a highly unequal metropolis, spatially segregated along lines of race and class. Louisville, Kentucky is a particularly worthy case for this type of study because of the race and class inequalities among neighborhoods within the city. One hallmark of neoliberal urban governance strategies is 
the reinforcement of race and class inequality (Spence, 2015; Weaver, 2016). Louisville residents often invoke the notion of the " $9^{\text {th }}$ Street Divide," a physical barrier in the form of an expressway ramp that divides the central business district from the city's predominately black West End (Rogers, 2018). The communities of study are the Russell and Portland neighborhoods, the boundaries of which are identified by census tract.

At the beginning of this research endeavor, to identify the neighborhoods for the study, data was used from the 2009-2013 American Community Survey (ACS) 5-Year Estimates census, available online. All of the census tracts in Jefferson County were compiled into an Excel spreadsheet and subsequently sorted in two main ways. The census tracts were ranked according to the highest percentage of African American residents, and then by tracts with the lowest median household incomes. After the tracts were ranked by race and class, they were then matched up to a map of the Louisville Metropolitan area to identify which neighborhoods were situated in the urban core.

I sought to compare one predominately white neighborhood of concentrated poverty with an economically comparable predominately black neighborhood of concentrated poverty. The purpose of this was to further interrogate the relationship between the carceral state, race, and class by comparing and contrasting the substantive citizenship of neighborhoods with different racial demographics and similar economic standing. If the carceral state impact on substantive citizenship between the two communities runs parallel, then it indicates that political economic factors beyond solely racial motivations are at work. Before detailing the data collection and analysis process I want to first create context and describe the city and neighborhoods that are the subject of the investigation. 
Louisville, Kentucky brands itself as a "compassionate city," yet it is also one of the most racially and economically segregated urban centers in the country according to various studies. The inequalities present in the city make it ideal for this study because the neighborhoods of isolated disadvantage allow for an examination of the carceral state's bearing on the urban poor along lines of race and class. Louisville merged with the surrounding Jefferson County in 2003 and is now the $14^{\text {th }}$ largest metropolis in the United States. According to a Metropolitan Housing Coalition report released in 2015, of the city's 760,000 residents, $74 \%$ are white and black residents make up about $20 \%$ of the population (Metropolitan Housing Coalition, 2015).

In a review of metropolitan areas, Kent and Frolich (2015) claimed Louisville, Kentucky was the fourth most segregated city in the U.S. Two zip codes in the city center, home to $2.7 \%$ of the area's population, house nearly $20 \%$ of the city's black population (Kent and Frolich, 2015). Using data collected 2007 and 2011, Jargowsky (2015) identified Louisville as having the fifth highest concentration of poverty among black residents with $41.4 \%$ of black people living in high-poverty census tracts. The highly educated and wealthiest residents of Louisville live in only a handful of zip codes (Serchuk, 2015). The Louisville-Jefferson County Metro median household income is $\$ 44,159$ and the per capita income is $\$ 26,098$ (Serchuk, 2015). In terms of education, $26.9 \%$ of the Louisville Metro population has a bachelor's degree and $11 \%$ of adults have an advanced degree (Serchuk, 2015).

A 2015 Urban Institute study identified Louisville as one of the top 15 most unequal cities in terms of neighborhood-level inequality (Pendall \& Hedman, 2015). The inequality rating was based on the difference between the composite score of the 
metropolitan area's top 10 percent of Census tracts and the bottom 10 percent. The score for determining advantage and disadvantage included an average household income, the share of the population with a college degree, the home ownership rate, and median housing value (Pendall \& Hedman, 2015).

A study from the Economic Innovation Group (2015) ranked Louisville in the top 10 cities with populations over 400,000 for having the greatest economic distress disparity, with $20 \%$ of city residents living in an area characterized as economically distressed. The Greater Louisville Project Report (2015) ranked Louisville as $3^{\text {rd }}$ from the last among 17 peer cities in terms of concentrated poverty, a list that includes Nashville, St. Louis, Oklahoma City, and Charlotte. Of 3,228 census tracts included in the study, the poorest tract in the Russell neighborhood is the $3^{\text {rd }}$ poorest overall and the poorest tract in the Portland neighborhood is the $10^{\text {th }}$ poorest overall (Greater Louisville Project, 2015).

One in seven Louisville residents lives in a neighborhood with dire economic circumstances that includes an income level $150 \%$ below the poverty line, higher unemployment rates, lower life expectancy, and a lack of health insurance (Greater Louisville Project, 2015). These class inequalities found in Metro Louisville fall starkly along lines of race. According to a 2014 federally funded Metro Human Relations Commission Report, $45 \%$ of all city residents live in extreme segregation, and $40 \%$ of African Americans live in areas that are $80 \%$ or more black (Downs, 2014). The Century Foundation report ranked Louisville as the $10^{\text {th }}$ worst city for concentrated black poverty in the nation with $43 \%$ of African American residents living in neighborhoods where the federal poverty rate is $40 \%$ or more (Jargowsky, 2015). 
Historical government practices at the local, state, and federal levels have led to the present day racial and economic segregation in the city (Mock, 2017). "Decades of discrimination and divestment have led to the high concentration of black residents in West Louisville. Racist fears and exclusionary housing and zoning policies have, for years, perpetuated the racial divide that splits the city between east and west" (Lopez \& Ryan, 2016). A recent project entitled Redlining Louisville highlights Districts created and mapped by the Home Owners Loan Corporation (HOLC) (Poe, 2015). Districts 11 and 13 , redlined by the HOLC, respectively correspond to the present-day Russell and Portland neighborhoods. District 13, Portland, was redlined with Dutch and Irish populations predominating and a black population of about $30 \%$. At the time Russell was 80\% African American (Poe, 2015). The practice of redlining is another example of state interventions functioning to maintain a race and class hierarchy.

Louisville presents the opportunity to understand the role of race in shaping urban life, because it is a place where structural inequality has been replicated over time. Many of the issues facing residents today have roots in the federal, local, and state policies that led to racial and economic segregation in urban centers nationwide. In addition, Louisville is a place with long-standing racial tensions existing in the city. After spending several weeks in Louisville leading open housing demonstrations, Martin Luther King, Jr. remarked he experienced more white resentment there than in any other place in the Deep South (Wright, 1985). Louisville was home to a residential segregation ordinance passed in 1914 that became the subject of the 1917 Supreme Court case of Buchanan v. Warley declaring the ordinance unconstitutional. In the early 1970s, the Ku Klux Klan marched on Broadway in response to a court order mandating a busing program to desegregate 
schools causing the deployment of the National Guard (Stevens, 1975). Hence, Louisville is a city with an extended history of both structural racism and racial tensions.

Writing on the lives of African Americans in Louisville, Kentucky between 18801930, George C. Wright (1985) describes a city where racial discrimination was deeply embedded, and where African Americans, "often accommodate[d] themselves to a second-class for fear of creating racial tension" (p. 16). Wright (1985) discussed discrimination in employment faced by blacks, including systematic exclusion from the police department and all other city government employment, a denial of access to public accommodations, and experiences of police brutality (p. 17). Into the early 1900s, African Americans often lived in deplorable housing conditions and black communities received either inadequate municipal services or did not receive them at all (Wright, 1985). Describing Louisville as the home of "polite racism," Wright (1985) wrote that, "the police force was an ever-present symbol of white authority, reminding AfroAmericans to remain in their place and that any attempts to change the racial status quo would be met with resistance" (p. 19).

Although Wright's (1985) text focused on African American life in the city of Louisville, in various passages he noted the ways in which the city also disenfranchised poor whites. Wright (1985) highlighted tenements with poor housing conditions scattered throughout town that also housed poor whites and immigrants. Richard Rothstein (2017) identifies this as a national practice to facilitate the access of lower-class populations to access work in the city. As Wright (1985) noted, during, "the last decades of the nineteenth century, Louisville's elite whites found it desirable to segregate not only blacks but also poor whites and "foreigners" (p. 51). Male High School was designated 
for white professional class males seeking preparatory training for college admissions, and Manual High School catered almost entirely to young white men from middle- and lower-class backgrounds to learn training in industry (Wright, 1985). There is simply insufficient academic literature exploring the lives of poor whites in an urban setting in modern America.

One primary contribution of this work is to consider how race and class interact to shape the type and impact of carceral state contact at the neighborhood level. A key question posed by this study is, are there variations of carceral state contact and its influence on the lived experiences of citizens in the city along lines of race and class, or the intersection of the two? Are there intra-racial differences observable in carceral state contact? The specific neighborhoods in this study present good cases for studying the interplay between race and class because of their similar economic standing and disparate racial demographics. Viewing Portland in contrast to Russell presents the opportunity to consider if there are racial differences in the carceral state's reach and impact in poor communities.

This research project was initially developed in 2014. As mentioned, at that time, the neighborhoods for the study were chosen using the 2009-2013 American Community Survey (ACS) 5-Year Estimates census data. What follows is a description of both neighborhoods, compiled using information from local newspapers that provides historical background and discusses recent economic development initiatives and revitalization strategies targeting both of the communities.

Russell \& Beecher Terrace 
The Russell neighborhood was named for Harvey Clarence Russell, Sr., declared to be a "specialist in Negro education," who served as a teacher and dean at Kentucky State College (Baye, 1989). In the 1980s the neighborhood was listed on the National Register of Historic Places due to its many Victorian style homes and stately mansions built after wealthy families moved in after the Civil War. Russell was home to a number of highly respected, and well-to-do African Americans during the late 1940s and into the 50s, including state representative Mae Street Kidd (Baye, 1989). Known as "Louisville's Harlem," the neighborhood housed the first library for blacks in the United States, the black newspaper "The Louisville Defender," and Louisville's high school for AfricanAmericans- Central High, where the world-famous boxer Muhammad Ali attended school (Baye, 1989).

The decline of Russell began during the 1960s when integration allowed middleclass blacks to exit the neighborhood and with the onset of urban renewal. According to local journalist Betty Baye (1989), "because much of the land acquired in Russell during urban renewal has never been fully redeveloped, the area's eastern end has become something of an invisible line that separates Louisville's mostly black West End from downtown," called the $9^{\text {th }}$ Street divide (para. 28). The interplay of various federal, state, and local policies leading to the hypersegregation of low-income black people identified by Cashin in 2004 occurred in the Russell area: redlining, the construction of the interstate highway system, urban renewal, and the siting of a low-income housing project.

Cashin (2004) describes in detail how each of these policy enactments created racial segregation in urban centers. She writes, "[T]he federal government through its Federal Housing Administration (FHA) mortgage insurance program, adopted and 
propagated the orthodoxy that homogeneity was necessary to ensure stable housing values... inventing and propagating the notion of redlining and initially locking out whole races and whole classes of people from the suburban dream.... The interstate highway program opened up easy avenues for escape from the city while at the same time destroying vital black, Latino, and white ethnic neighborhoods... [T]he federal government, through a number of urban development programs, created the black ghetto... the federal public housing program, by design and location of public housing projects, created the modern phenomenon of concentrated black poverty" (p. 103).

Situated in the Russell neighborhood, a community subjected to the federal urban renewal program, is the low-income housing property Beecher Terrace. The housing project of Beecher Terrace was originally built to house WWII defense workers, but eventually transitioned into federally subsidized public housing specifically for AfricanAmericans. In a Louisville Leader paper from November 2, 1940, of the housing development it was written, "[t]his housing project represents a great step forward for the Negro race in Louisville. We believe that it will result in the establishment of a higher standard of living for Negro families of the low -income groups" Here we can see the explicit segregation of the community by government agencies.

A 2015 Frontline episode entitled "Prison State" claimed 1 in 6 residents will spend time in jail or prison and that the state spends $\$ 15$ million per year housing prisoners from Beecher Terrace (Jones, 2015). Russell is one of the ten neighborhoods that accounted for more than half of the violent crimes in the city in 2014 (Bowling, 2015). In July 2016, the city received a $\$ 1$ million grant from the U.S. Department of Housing and Urban Development as part of its Choice Neighborhoods Initiative to 
revitalize the neighborhood of Russell (Bowling, 2016). Louisville is the only city in the country to receive all three types of grants, for planning, action, and implementation, from the CNI program that is the progeny of Hope VI (Vision Russell, 2018).

\section{Portland}

The founding of the formerly independent city of Portland dates back to the early 1800s when freights and passengers traveling on the Ohio River made it a stop (Herron, 1989). Annexed by the city in 1850 , Portland is now the largest neighborhood in the city with 13,000 residents (Historic Portland, 2018). It is one of the city's oldest neighborhoods and during the Civil War era, a number of Portland men joined the Ninth Kentucky Regiment to fight for the Confederacy (Herron, 1989). It also experienced waves of immigration during the 1800s including the French, then Irish, then Germans (Historic Portland, 2018). During the "Portland boom" wharves and warehouses lined the streets, but these began to empty in 1871 when the Portland Canal was widened to accommodate larger boats (Herron, 1989).

While Portland began as a flourishing river port as a neighborhood situated on the banks of the river, floods were an ever-present threat, and the "Great Flood" of 1937 devastated the community. "[T] he wharf was submerged under 30 feet of rushing water for nearly a month, and the city declared the site unlivable and promised a park that would be built there instead" (Stevens, 2014). Ultimately, a floodwall was built, delayed in construction by World War II, in addition to an expressway, the Watterson, that ran through Portland (Herron, 1989; Stevens, 2014). Again, we can see the construction of the interstate highway system as contributing to the state of the community today. 
Portland experienced migration during the 1950s and 70s when many younger residents moved south and east to follow industry that had moved out of the neighborhood (Herron, 1989). In addition to the migration of residents, commercial activity declined after the building of the floodwall that created a concrete barricade between the neighborhood and the river. According to historian Rick Bell, "workers began moving to the newly established community of Shively, called New Portland by many residents, and neighborhood institutions like local churches, stores, and other commercial enterprises began shutting down or moving out" (Stevens, 2014).

Portland is currently undergoing a period of revitalization, initiated approximately four years ago and spearheaded by one developer in particular, Gill Holland (Bowling, 2015). Holland leads a 10-year, \$25 million Portland Investment Initiative Plan seeking to draw businesses into the neighborhood and update its housing stock. The Initiative is promoting private and nonprofit partnerships to promote development. For example, New Directions, a housing nonprofit serving low-income and elderly people, signed an agreement with the Initiative to manage 30 renovated homes in the neighborhood with the goal of creating a mixed-income community (Bowling, 2015).

Despite claims from Holland that he is seeking to include existing residents in the process of revitalization, according to one Portland resident, "many residents felt excluded from the planning process... with few aware of if or when community meetings with Holland take place. That leaves them feeling nervous about their future" (Stevens, 2014). Portland, however, still has more than 1,000 vacant and abandoned properties and is included in the list of ten neighborhoods that saw more than half of the violent crimes 
in the city during 2014 (Bowling, 2015). Regarding the recent development, one local news outlet

reported that, "some current residents and community activists are concerned that the historical and architectural character is worth more to developers than the human character of the historically working-class neighborhood" (Stevens, 2014).

\section{A Closer Look at the Neighborhoods, Data Collection}

The data for the case study is triangulated and is pulled from various quantitative and qualitative sources to strengthen the validity of claims made by this project. The research data is comprised of demographic descriptions of the neighborhoods compiled from census statistics, survey and arrest data to help ascertain the frequency and nature of resident encounters with police, and individual interviews and focus groups with residents to examine their substantive citizenship experiences.

\section{Census Data}

The following table displays the selected demographic and economic characteristics of each of the neighborhoods using 2015 ACS 5-Year Estimates data. As mentioned, these two census tracts were among the top ten poorest in a study of over 3,228 tracts in 17 peer cities.

\section{Table 1. Selected Community Characteristics}




\begin{tabular}{|c|l|l|}
\hline & $\begin{array}{l}\text { Portland } \\
\text { (Census } \\
\text { Tract 2) }\end{array}$ & $\begin{array}{l}\text { Russell / Beecher } \\
\text { (Census Tract 30) }\end{array}$ \\
& & \\
& & \\
\hline Total Population & 3,051 & 3,526 \\
Total family households & 629 & 721 \\
\hline Housing tenure & & \\
\hline$\%$ vacant units & $29.1 \%$ & $7.4 \%$ \\
\hline$\%$ renter-occupied units & $58.6 \%$ & $100 \%$ \\
\hline Racial and ethnic composition & & \\
\hline$\%$ non-Hispanic White & $73.8 \%$ & $10 \%$ \\
\hline$\%$ non-Hispanic Black & $24.7 \%$ & $85 \%$ \\
\hline Socioeconomic characteristics & & \\
\hline $\begin{array}{l}\% \text { in labor force population 16 } \\
\text { years and older }\end{array}$ & $\begin{array}{l}48.8 \% \\
(1,956)\end{array}$ & $\begin{array}{l}48.8 \% \\
(2,206)\end{array}$ \\
\hline \% Income in the Past 12 months & $23.2 \%$ & $46.2 \%$ \\
\hline 9,999 or less & & \\
\hline $\begin{array}{l}\text { Median household income (US \$) } \\
\text { Families }\end{array}$ & $\$ 30,995$ & $\$ 9,190$ \\
Nonfamily households & $\$ 18,125$ & $\$ 9,488$ \\
\hline$\%$ below poverty level & $31.3 \%$ & $84.5 \%$ \\
\hline$\%$ less than high school graduate & $27.9 \%$ & $29 \%$ \\
\hline$\%$ high school graduate or higher & $40.7 \%$ & $40.2 \%$ \\
\hline$\%$ bachelor's degree or higher & $3.4 \%$ & $1.3 \%$ \\
\hline & & \\
\hline
\end{tabular}

Arrest Data

Arrest data was obtained from the Louisville Metro Police Department (LMPD) between the dates of January 1, 2015 through October 1, 2016. The data from LMPD 
included all arrests in the neighborhoods, identified by census tract, and contained demographic information of the arrestees (race, gender, and age), and the charges, and the location of the arrest. The data was coded to categorize the type of crime for the most serious offense for which the individual was arrested. Then, with the help of a GIS specialist, the data was mapped and can be accessed in full at the following link: https://tinyurl.com/jcf75sp.

LMPD arrest data provides a larger snapshot of how often individuals are experiencing contact with police and the types of charges for which people are being arrested. The decision to arrest is discretionary, and therefore, the types of charges and who is being arrested is also indicative of how officers are exercising their discretion. One limitation, however, is that arrests do not indicate how often individuals in the neighborhood are stopped and questioned without arrest and the survey seeks to fill that gap. The arrest data is included below.

Table 2. Arrest Data

\begin{tabular}{|l|l|l|}
\hline & $\begin{array}{l}\text { Portland } \\
\text { (census tract 2) }\end{array}$ & $\begin{array}{l}\text { Russell / Beecher } \\
\text { (census tract 30) }\end{array}$ \\
\hline Total Individuals Arrests & 680 & 930 \\
\hline $\begin{array}{l}\text { Percentage African American } \\
\text { Arrestees }\end{array}$ & $21.1 \%$ & $79.2 \%$ \\
\hline Percentage White Arrestees & $78.6 \%$ & $20.5 \%$ \\
\hline Arrest Class & & \\
\hline Felony & $35.1 \%$ & $29.5 \%$ \\
\hline Misdemeanor & $51 \%$ & $45.6 \%$ \\
\hline Violations & $7.5 \%$ & $16.9 \%$ \\
\hline Traffic & $2 \%$ & $3.2 \%$ \\
\hline Type of Charge & & \\
\hline Drug Possession & $38.5 \%$ & $32.3 \%$ \\
\hline Property Crimes & $10.5 \%$ & $20.8 \%$ \\
\hline $\begin{array}{l}\text { Violent Crime } \\
\text { (against person) }\end{array}$ & $11.4 \%$ & $8.9 \%$ \\
\hline Theft & & $3.9 \%$ \\
\hline
\end{tabular}




\section{Surveys}

Surveys created by the researcher constitute one of the quantitative data sets used in the study, however their use in the study is limited due to some matters that will be reported later in this section. The survey was developed through a review of another instrument, the Bureau of Justice Statistics Police-Public Contact Survey. The survey devised for this study asked questions related to the amount and type of recent police contact experienced by respondents, if any, and also sought to measure the depth of carceral state contact in prior years. It asked if an individual had been stopped in the previous year and if so, how many times. It also asks a series of questions regarding the survey taker's most recent stop. The survey helped resolve gaps existing in the available data from Louisville Metro Police Department, as there are no records of the number of people who are stopped by police and subsequently let go with no citation or arrest. There are also people who are stopped and searched by the police but released and these numbers are also absent from the LMPD data.

Additional questions were included to assess perceptions of fairness in police encounters and to measure community engagement. Fairness stood as an important concept to attempt to measure because of Tyler's (2006) studies on procedural justice. Tyler (2006) found that people's assessments of justice and the system relate to whether or not they feel they were treated fairly during the process. Therefore, people were asked if they felt they were treated fairly during their most recent stop and if so, did they believe it was based on their race or their neighborhood. There were two different versions of the survey administered to respondents and in chapters four and five, the different survey iterations are referenced separately in reporting. 
Not only did the surveys gain a broader picture of the nature and quality of carceral state contact and its impact, it also served as a means of recruitment for subsequent focus groups and one-on-one interviews for the study. The data collection process for this study occurred in waves, beginning with canvassing and concluding with interviews conducted in the community. I collected survey data through canvassing with volunteers and through attending community events in the neighborhoods. Volunteers were identified through sending email blasts to community organizations and social media.

Before beginning the first series of community canvasses, two trainings were held for volunteers to learn about the purpose of the study, how to canvass, and to discuss responding to questions that may arise when administering the survey. Surveys were conducted from October of 2015 until May of 2017. 110 surveys were collected from residents of the Russell neighborhood and 44 surveys were collected in Portland, accounting for 154 surveys from the two communities.

Sampling for this research was two-fold. Naturalistic sampling, where the researcher speaks to a variety of participants encountered in the community of study, and snowball sampling were used to collect data and identify interviewees. On various occasions between October of 2015 through May of 2017, I canvassed the communities of Russell and Portland with anywhere from four to twelve trained volunteers. In addition, I tabled at community events and at non-profit organizations in the communities to recruit survey-takers and interviewees.

As explained, the neighborhoods were identified along census tract lines and it was confirmed with potential respondents that they lived in one of the neighborhoods of 
study. During canvasses, residents were first asked if they were willing to participate in a survey regarding the criminal justice system and on completing the survey were asked if they would be willing to discuss their community and the criminal justice system in further detail.

\section{Interviews}

The interviews comprise the crux of the data for this case study and are attuned to understanding citizenship experiences from the perspective of the residents. Using the qualitative data, I provide a narrative description of the respondent's social, political, economic, and mobility worldviews and parse through how they describe their interactions with the local government and carceral state. Interview questions were created through the multidimensional framework specified in the previous chapter called "citizenship in the city." Using the four-part frame, I investigate how residents position their status in the city based on community-level experiences with the carceral state. How do people experience democracy in the city? By democracy, I mean voice and decisionmaking power in the local institutions that govern people's lives.

Qualitative methods lend themselves to developing comprehensive accounts of systems and processes, in addition to identifying factors and new hypothesis for future research. Because this research grapples with very expansive concepts such as urban governance and citizenship, qualitative research provides the rich data to aid in understanding the city as a system with interrelated parts including the people who inhabit the space and the institutions with which they interact. Qualitative data is best 
suited to exploring the lived experience of urban citizenship for neighborhood residents. Rich, local information can be derived from a qualitative research project. In comparison, large- $n$ survey analyses can obscure the more detailed narratives and thick descriptions people articulate about government and engagement with government institutions.

The survey collection aided in identifying interview participants for the study, however, scheduling respondents in this way proved to be difficult. The rate of attrition between the initial contact and the day of the focus group was incredibly high, with a number of no-shows if a substantial period of time passed. Therefore, I found it best to conduct the focus groups on site following recruitment or within a day. For example, at the Baxter community center, I attended "open gym" hours, where anyone could come play basketball, to solicit willing participants for a focus group and then, conducted it once I drafted enough participants. Attending community events and recruiting on site for survey and interview participants proved to be the most reliable method of identifying study participants. The snowball method helped identify additional residents to interview. Two of the Beecher Terrace focus groups came together by residents who already participated in the study bringing additional participants to interview. Staff at the various community-based sites would aid in recruitment as well through keeping recruitment flyers on site and introducing me to willing participants.

I conducted the interviews at locations in each of the two communities, the Baxter Community Center in Russell, and The Table and Neighborhood House in Portland, or at the respondent's home. Interview participants received a $\$ 20$ Visa gift card for their time. I collected demographic data and assigned focus group participants a number before interviews begin to help maintain anonymity. The study was Institutional Review Board 
approved, and the consent paperwork was also collected prior to beginning the interviews and focus groups. A total of 72 respondents participated, 29 from Portland and 43 from Russell/Beecher. 40 of the Russell residents were housing project residents, three lived in the Russell neighborhood at apartments on the border of the housing complex, and two of the individuals interviewed in Portland were without stable housing and identified as homeless. Recruiting younger respondents proved to be difficult for the researcher, and there is an overrepresentation of participants aged 50 and older. I also hoped to attract more white participants, but Portland was an especially difficult neighborhood in which to recruit overall.

The qualitative data is constituted by a mix of focus groups and one-on-one interviews and lasted anywhere from 35 minutes for one-on-one interviews to upwards of 90 minutes for focus groups. Some interviewees had a great deal to say, other participants very little, and this lent itself to the varying times between shorter one-on-one interviews and the lengthier focus groups. The focus groups also varied in size and at least three individuals constituted a focus group, but most were larger. Much of this variation in size depended on how many people attended. Included in is a breakdown of all of the interviewees with their demographic information and individual income under $\$ 10,000$.

\section{Table 3. Interview Respondent Demographics}

\begin{tabular}{|l|l|l|l|l|l|}
\hline & $\begin{array}{l}\text { Race } \\
\text { (white) }\end{array}$ & $\begin{array}{l}\text { Race } \\
\text { (black) }\end{array}$ & $\begin{array}{l}\text { Sex } \\
\text { (male) }\end{array}$ & $\begin{array}{l}\text { Sex } \\
\text { (female) }\end{array}$ & $\begin{array}{l}\text { Income } \\
\text { (under 10k) }\end{array}$ \\
\hline $\begin{array}{l}\text { Portland } \\
(30\end{array}$ & 17 & 13 & 10 & 20 & 14 \\
interviewees) & & 43 & 19 & 24 & 30 \\
\hline $\begin{array}{l}\text { Russell } \\
(43 \\
\text { interviewees) }\end{array}$ & 0 & & & & \\
\hline
\end{tabular}


Three focus groups were conducted in Portland, one included 8 black and white participants aged 49 to 81 (this was conducted at a day program for the elderly), and two others were smaller with 3 and 4 participants and were conducted at The Table. These smaller focus groups were also mixed by race and gender, and the participants ranged in age from 21 to 68 . In Russell one focus group included 5 black males, all under the age of 25, two different focus groups included 6 and 7 participants who all identified as black and were aged 51 or older. The fourth Russell focus group was comprised of 7 participants, men and women, aged 22 to 43 . Of the Portland interviewees the overall ages ranged from age 21 to 81 , and the Russell community respondents ranged in ages 18 to 74 .

Respondents were asked a series of questions about their views on their neighborhood, the local Louisville Metro Government, and their thoughts on the carceral state and any relevant experiences they may have had with the carceral state. The interviews were transcribed and reviewed by the researcher to identify the existence of consistent themes arising from the interview data. There are a few clear limitations to the non-random sample. As mentioned older respondents dominated the non-random sample leading to an elevated median age of the interviewees. There were also a substantially smaller number of white participants, 17 in total, making racial comparisons much more tenuous. Lastly, 40 of the interviewees lived in a housing project development in Russell, making local government the primary administrator of the community where they lived.

\section{Barriers}


While there are handbooks and textbooks detailing best practices in designing and collecting surveys and in conducting focus groups and individual interviews, the reality is time and resources impact the data collection process. I used university-provided research funds to pay participants, and this was the only expenditure for this study. In addition, at various points undergraduate students helped with focus group and interview recruitment, the coordination of the interviews, identifying and communicating with community stakeholders, transcribing the data, coding data, and note taking during interviews. This assistance from students helped tremendously. In the future, to undertake a project of this size it would be a great benefit to have a paid, experienced research coordinator. Also, ideally every conducted focus group would have a moderator and a note-taker, this would also aid in collecting the most accurate demographic data and gaining consent during the interview sessions. In some focus groups and interviews I served as both the moderator and the note-taker.

The communities selected for the study also posed a barrier. In both communities there seemed to be a low trust of outsiders. At an open gym session at Baxter Community Center I was asked if I was the police, and this happened again while interviewing at the Table. Trust had to be built over time, I had to continually show up and become a recognizable face in the spaces where I was recruiting. In addition, door knocking in Beecher Terrace was much easier in comparison to Portland. To continue doing this research I believe that canvassing volunteers should look like people in the community. In my estimation, groups of white volunteers may have been more effective in Portland. Also, a white moderator to conduct the interview could have allowed white 
interviewees to speak more freely about race than when the moderator is a person of color.

Literacy posed another barrier. To survey about the criminal justice system was difficult because people were not necessarily familiar with the language of bond, dismissal, and being able to identify criminal justice terms and outcomes. This taught me that while people may have carceral state contact and be processed through the system, they do not necessarily understand what is happening to them or why it is happening and the specific procedures of the justice system. Also in terms of literacy, in the low-income, low-education level communities I realized the words used in interviews were critical to engage with residents. As a college-educated individual I had to learn to shape my vocabulary and keep my questions simple and straight to the point. This is not to say that the individual residents were less intelligent, rather the gap between formal education and limited education created difficulties in communication and understanding.

\section{Limitations}

This study investigates two neighborhoods in one city, making the findings difficult to generalize, and this is one primary limitation to the study. Also, the sample was a non-random sample that failed to reflect the demographics of both neighborhoods. For example, based on the census data, Black interviewees were over-represented in the Portland interview data. This makes the racial comparison more tenuous because of the low number of white interviewees. The same is true for the age of the interviewees, older residents were overrepresented because of how the recruitment unfolded, and also older residents seemed generally more interested and willing to participate. Because forty of 
the interviewees in Russell lived in a public housing development, this also influenced the outcome of the study because these residents lived in a government -owned housing complex. While there are limitations to the study, the findings in the next two chapters aid in answering the research questions and have implications for the literature that are described in the conclusion. 


\section{CHAPTER FIVE: HYPERSEGREGATED \& HYPERPOLICED}

"They don't care nothing about the people living in these bricks" - Beecher Terrace resident

Envisage living in a community where police interact with you or your neighbors on a daily basis. While performing routine tasks like going to work or grocery shopping, you may be followed, stopped, detained, and questioned. Or, officers might approach you while you sit on the front porch of your apartment socializing with neighbors. Living in a hyperpoliced community, you might witness random stops of your neighbors, especially groups of young black men, who are asked for their identifications so officers can check for warrants and search for possible contraband. Everyone traversing through this urban space is a suspect. Contact with police in this neighborhood, where the vast majority of residents are black and poor, is a predictable, everyday part of life.

Other carceral state interactions, such as appearing at the courthouse located only blocks away or spending a day or two in jail, become expected dimensions of neighborhood life. It is not uncommon for a family member or neighbor to scrap together cash for bail, to pay a fine, or to purchase items such as toothbrushes and food for incarcerated loved ones. Nor is it an exceptional occurrence for one's home life to be upended by the absence of a parent, or to encounter carceral state authorities at a young age. As a resident of government administered housing, the local housing authority and social aid institutions also monitor your activities through home checks and the 
supervision of work requirements. These constant, punitive interventions by state authorities send the message to you and your neighbors that the people living in this community require consistent regulation and surveillance by the state.

Interviews with the residents of Beecher Terrace, and three individuals living on the outskirts of the housing project, helped generate this narrative of community hyperpolicing. The account illustrates just how ubiquitous carceral state contact is in the community, making it a powerful force in shaping the substantive citizenship of residents. In addition, other institutions that surveil residents shape the real content of their daily lives in the community where they live. Persistent, punitive state interventions characterize the lives of Beecher residents.

Interactions with police, appearing in front of judges, and familiarity with the carceral state through personal or indirect contacts highlight the integral connection between space and citizenship in the city. To use the terminology of Lerman and Weaver (2014) everyone in the neighborhood becomes a "custodial citizen," partially because of how the community is defined socially. State interventions in Beecher Terrace are ubiquitous and punitive. Residents encounter a state that views them as deviant based on their race and class, and this justifies persistent state interventions to calibrate resident behavior. This targeting of particular communities, and specifically poor neighborhoods, for monitoring and surveillance is a hallmark of neoliberalism in local government.

This chapter systematically details how residents from Russell, and primarily Beecher Terrace, experience citizenship in the city through an analysis of community member interviews using the four frames outlined in Chapter 3: economic, political, social, and mobility. 43 residents participated in focus groups or one-on-one interviews conducted 
from November 2015 to February 2017; all were African-American and were an average age of 42.3 years. 24 respondents were women, 19 were males, and the vast majority, 30 individuals, reported an income of $\$ 10,000$ or less per year. The chapter begins by highlighting how community members discuss the neighborhood where they live, and how they position their neighborhood in the broader context of city life. Residents see their community as disenfranchised and disempowered, suffering from violence and crime, but also as home where their social networks are the strongest.

The chapter then moves into a brief discussion of the collected survey and arrest data to help provide a picture of carceral state interventions alongside the qualitative reporting of residents. A more complete discussion and charts of the surveys and arrest data are included in Chapter 4. Afterward, this chapter uses resident reporting to detail how the community is policed and to describe community interactions with the criminal justice system. Then using the four-part frame of citizenship in the city I will systematically discuss how the carceral state shapes resident's substantive citizenship in a way that keeps a durable hierarchy along lines of race and class intact. In this section, I consider how the interviews reflect or depart from current literature and will further engage space as an integral component of Lerman and Weaver's (2014) concept of custodial citizenship.

This chapter then concludes by discussing race and the carceral state. Here the chapter seeks to nuance the literature on race and the carceral state by making two key points. First, that the carceral state functions to both socially control African- Americans and is further incentivized to generate profits from the subjugation of black bodies. The latter claim may seem far-fetched, but as will be discussed below, the Ferguson 
Department of Justice Report detailed the use of the carceral state to generate state revenues at the expense of local black residents and the interviews in this study reflect the similar practices. From these elements of social control and the distribution of economic resources via the carceral state, we are able to see how the state actively maintains a hierarchy between social classes and groups along lines of race and class in way that shapes the substantive content of citizenship in the city.

I further seek to complicate the literature on race and the carceral state by highlighting the importance of parsing through the ideological and structural manifestations of race and racism. Racial ideology normalizes racial subjugation and the systemic, unequal racial outcomes in institutions and the political economy. Instead of seeing a flawed system, race teaches us to see flawed people. In the next chapter, I also argue that racial ideology functions to "hide the gap" of wide economic disparities between whites. Finally, my key point about racial structures is that it is imperative for scholars to consider the embeddedness of race in the American political economy and the ways race transforms and changes overtime while maintaining the existing hierarchies of race and class. This is why Michelle Alexander's (2010) work on The New Jim Crow is so powerful, because it acknowledges that American society and its democratic institutions may not have successfully broken from its white supremacist roots. Therefore, this chapter accomplishes two main tasks. First, it adds to the discussion of custodial citizenship by incorporating the dimension of space, and specifically the urban neighborhood space. Second, it nuances the literature around race and the carceral state.

\section{The Neighborhood}


Residents described the community of Beecher and Russell in overwhelmingly negative terms, while also referring to it fondly as home. Violence, drugs, and crime featured prominently in resident responses when probed about words they would use to characterize their neighborhood. Older interviewees often framed violence in the neighborhood as the result of changing norms of morality among young people and also, a lack of accessibility to good jobs. An exchange among the women in one focus group illustrates how the lack of supervision for young people was connected to the quality of life in the neighborhood. One respondent began, "The kids, the children, they need more discipline. I'm telling you, the kids is just..." Another woman chimed in "Yes, the kids. They disrespect the elders." And a third participant agreed, adding that, "With the kids, you would think they supposed to be in the house, on school nights, they out late as I am."

This interaction among interviewees represents a larger thread in the interview data identifying the individual responsibility of residents and moral codes as the progenitor of crime and violence in the community. Fortner (2015) attaches this individual responsibility and tough on crime philosophy to class divisions in the black community. He explains, "Within urban communities across the United State, workingand middle-class African Americans differentiate between 'us' and 'them,' between 'decent families' and 'street families.' And 'decent families' do not believe their fate is linked with the fate of "street families"' (p. 14). Here, however, there is no class distinction that can help unpack why interviewees adopted an individual responsibility view of crime and systemic poverty in their communities. The vast majority of interviewees were both unemployed and generated an income of $\$ 10,000$ or less per year. 
What did seem most salient, however, was that older residents most commonly proclaimed the moral perspective.

Another thread among interviewees, sometimes articulated by the same person who invoked individual responsibility, argued crime and violence resulted from a lack of good jobs and access to resources. No places to shop, no places to buy groceries, no places for children to safely play, and inadequate trash pickup were discussed among all of the interviews. This represents a structural view of the crime and violence in the community that looks toward the built environment and the lack of resources and amenities in the neighborhood as the culprit.

This is not to say, however, that the articulations of community were entirely negative. In this vein, community members talked about some of the social networks they built with and among their neighbors. These social support networks were particularly salient among women respondents. While people maintained a general distrust of others due to violence in their community, many of the women residents in particular talked about "looking out for each other," whether it was through sharing food or information about available resources. Also, through their roles as mothers, women were often left to be the primary support for families when their family members became involved with the carceral state. In this way, residents, while having negative perceptions of their neighborhood, also saw it as home, and a place where they wanted to remain because it was where their social networks were strongest.

\section{Carceral State in the Community}


As detailed in Chapter 3, I conducted surveys to measure the quantity and type of contact with the carceral state residents experienced. Recall that the survey questions changed and surveying took place in two waves. I revisit some of this data here to help illustrate the ubiquity and nature of carceral state contact in the community of study. In the first round of surveying 57 total respondents participated and their responses regarding police stops are included below. In the second wave of surveying, 38 respondents participated from Russell. The following chart briefly highlights key findings from these surveys and the stops experienced by residents in the neighborhood.

\section{Table 4. Survey Responses}

\begin{tabular}{|l|}
\hline Round 1 \\
Stopped in the past year \\
$58.5 \%(28) \mathrm{n}=57$ \\
Result of the stop $\mathrm{n}=28$ \\
(could indicate multiple responses) \\
Searched: $89 \%$ (25) \\
Arrested: $39 \%$ (11) \\
Received citation: $25 \%$ (7) \\
Officer warning: $36 \%(10)$ \\
Round 2 \\
Stopped in the past year \\
$57.8 \%$ (22) $\mathrm{n}=38$ \\
\hline Stopped multiple times in the past year \\
$59 \%(13) \mathrm{n}=22$
\end{tabular}




\begin{tabular}{|l|}
\hline Searched during the most recent stop \\
$77 \%$ (17) $n=22$ \\
Felt treated unfairly during the most recent \\
stop \\
$68 \%(15) \mathrm{n}=22$ \\
\hline
\end{tabular}

Although the two waves of surveying show different questions with a limited pool of respondents, the descriptive data arising from the surveys does help illustrate carceral state contact in the neighborhood. First, individuals living in this community are the subject of persistent police stops. Over half of the total individuals surveyed between the two iterations indicated police stopped them at least once over the course of the previous year. Also, most people who are stopped are also searched and according to the first round of surveying well over one-third end up arrested. Searches and arrests by police are discretionary, and the survey data seems to indicate that officers are more likely than not to use their discretion to conduct a search or arrest the individual.

In addition, from the second round of surveying the vast majority of those who were stopped, almost 70\%, felt the police treated them unfairly, and most of them believed the unfair treatment resulted from their race and neighborhood. The second round of surveys asked individuals to elaborate on why they felt they were treated unfairly and responses included: "because a lot of police officers do not like black people in our neighborhood," "they look at us like we dogs," "because I'm black," and "because I'm a teenage black male posting outside with friends." The interviews with community 
members reflected these same sentiments around policing, that they are profiled because they live in a neighborhood that is black and poor.

Looking at arrest data from the Louisville Metro Police Department for this neighborhood, from October of 2015 through October 2016, there were 927 different arrests in a neighborhood of 3,000 people. This averages out to 2.5 arrests happening in the community every day of the year. The largest proportion of the arrests was for drug possession, with $32.3 \%$ of arrests in the community being for this type of offense. The next highest proportion of arrests was for property crimes, including trespass, loitering, criminal mischief, disorderly conduct, and drinking alcohol in a public place; these constituted $20.7 \%$ of arrests. These types of arrests indicate order maintenance and broken windows policing practices that monitor and arrest for low-level offenses. Therefore, over $50 \%$ of the arrests are for non-violent offenses.

The quantitative data paints a picture of ubiquitous police contact in the neighborhood. Alexander (2010) identifies prolific carceral state interventions, sweeping up residents in poor communities of color, as the initial "roundup" phase of mass incarceration (p. 185). While Alexander ties the roundup to the drug war and police conducting drug operations, the arrest data presented here shows that order maintenance policing also contribute to large numbers of people entering into the criminal justice system. Broken-windows-style policing is presented by the data. For example, a large number of criminal trespass charges are revealed by the arrest data. Although these offenses may not lead to prison incarceration, they profoundly impact the citizenship of residents. The resident narratives mesh with the survey and arrest data and help unpack how frequent carceral state contacts in the neighborhood impact substantive citizenship. 
Residents described the carceral state as an omnipresent, aggressive mechanism of social control. Returning to Chapter 1, we are reminded of the historical use of the carceral state to manage black populations through mechanisms of legal coercion. Imani Perry (2011) identifies the contemporary heightened surveillance of black communities as one example of a "practice of racial inequality." According to Perry (2011), "Racialized practices of surveillance leading to a loss of the right to privacy is justified through racial narratives about disorder, invasion, and moral decay" (p. 86). In discussing both police and social welfare monitoring, Perry explains that, "practices of exposure and surveillance that deny privacy emerge, in part, from popular narratives of disarray and depravity in communities of color and the 'need' for disciplining intervention" (p. 94).

Neoliberal broken windows policing practices are grounded in narratives of disorder in city space. Here we are able to observe the interconnection between colorblind racism and neoliberalism because what is perceived as urban disorder is intimately interconnected with race and poor communities of color. Quillian and Pager (2001), found that the percentage of young black men in a neighborhood, "is significantly associated with perceptions of the severity of the neighborhood's crime problem" ( $\mathrm{p}$. 718). Seemingly colorblind, race-neutral neoliberal narratives about disorder and the need for discipline in certain communities become entangled with racial ideologies that tag neighborhoods of color as disorderly.

Punitive state interventions were so common in the community of study among young black men, they articulated carceral state contact as a way of life. In one focus group comprised of African-American men under age 35 when asked what city government meant to them, one respondent answered, "I think of paddy wagons and I 
don't know, CCC and like court dates and shit like that." One participant in the same focus group explained that the criminal justice system was not the biggest part of government but "that's what we know." The conversation continued, and participants described a community where if you are not dead, you're in jail and, if you're not in jail or dead, "you already been locked up before.” This quote reflects the powerful shaping force that is the carceral state in the lives of young black men living in a poor neighborhood.

Among interviewees, contact with government most often occurred through interactions with the police who represented the most visible state authorities. Lerman and Weaver (2014) found that for custodial citizens "criminal justice authorities were their most proximate (and memorable) experience of government," describing carceral state contact as a form of civic education (p. 15). In the current study, this was true not only based on direct contact with the state but because of the neighborhood where the interviewees resided where police encounters occurred with frequency. Resident descriptions, across all age groups, viewed police in an overwhelmingly negative light. Interviewees consistently highlighted not only the frequency of interactions with police, but also the abusive tenor of the interactions. Harassment was a consistent characterization of police activity in the community through frequent stops and interrogations.

Across multiple focus groups and interviews narratives of police abuse and harassment were combined with stories of the physical violence perpetrated by officers on community members. One woman lamented that officers policing the neighborhood were too quick to draw their weapons. Another black male respondent claimed officers 
would say, "Come here," then "jack you up, choke you up, all that, they don't care." In an interview comprised of elderly residents aged 50 and up, one gentleman described the police as abusive. The stories and specific instances of brutal police encounters described by residents were harrowing. A woman reported being tackled to the ground by 4 officers and in another incident witnessing police punching a man who was having seizures for not laying down in the ambulance. Another woman said she witnessed a fight in the community and claimed the responding police officer said, "I'm gonna take these pictures and take 'em back and see if any of y'all have warrants. Then I'mma let y'all kill each other."

Residents also expressed concerns about what happens when police are called to the area to assist with an incident. One respondent explained, "when you want them, they not there. When you need them they not there, but if you ain't paying attention to them, they right there." Another interviewee said, "When you call the police, you get badmouthed because you called. Just because we all live in this neighborhood, we all have to be treated the same?" Due to the community's race and class dynamics, all individuals in the neighborhood felt stereotyped and stigmatized by police and the broader apparatuses of local government. The existence of a community-wide stigma learned by residents through daily interactions with state authorities is a common thread in the literature on the spatial concentration of criminal justice interventions found by Rose, Ryder, and Clear (2001).

The stigma that comes to be attached to neighborhoods is one way that the carceral state functions as a "race-making institution," as Wacquant (2005) and Lerman and Weaver (2014) have referred to it. As a race-making institution, the carceral state 
moves, "beyond merely reflecting racial dynamics and social understandings in the wider society, it actively 'shapes racial experience and conditions meaning,' defines racial identities and membership, and positions racial groups (Lerman and Weaver, $2014 \mathrm{p}$. 157, citing Saperstein \& Penner, 2010). The interviews identify the production of racial ideology through the carceral state; a stigmatizing narrative is generated that tags all residents as criminal and deviant in a black, hypersegregated community of poverty. Space is also integral to the race-making function of the carceral state through the stigmatization of the entire community and a normalization of the hyperpolicing in the community.

There was a clear lack of trust for officers in the community, and further, residents felt like the police department failed to ensure public safety. Working with the police to help stop crime was discussed in various focus groups, and interviews with residents indicated the dangers to themselves for interacting with police. One resident explained, "The police ask us if we want to be on block watch- why are they trying to get us killed?" Another gentleman interviewee, recently detained in jail for a misdemeanor, said an officer asked him to provide 3 key names from Beecher Terrace. He explained, "Even if I do give him the information, we can get killed."

These types of interactions with police, the most visible manifestation of local city government, are informative on the social place of citizens in the city and teach them about their political power. Residents learn that based on their race, class, and neighborhood, their position in the urban society is at the bottom of a hierarchy. This position renders all community members as suspicious and justifies coercive surveillance that makes them powerless in the face of state authorities. 
There is a caveat to narratives on aggressive police patrolling that is worthy of closer observation. Some residents, and particularly older residents, felt safer with heightened police presence, and they articulated a fear of young men hanging out around the neighborhood "up to no good." Also, many older residents felt the criminal justice system was too lenient and that defendants received only a slap on the wrist and were released too soon. I read this as part of the individual responsibility narrative that is a hallmark of neoliberal ideology. This perspective was also identifiable in the way people talked about unsupervised, out of control children whose parents maintained a deviant lifestyle as the cause of havoc and crime in the neighborhood. Although, some of the older residents who expressed a desire for an increased officer presence also articulated the issues and concerns surrounding police and policing discussed throughout this chapter.

Lerman and Weaver (2014) encountered similar contradictory narratives in their interviews with black respondents. They write, "In essence, blacks were left without a coherent framework to explain persistent racial inequality. Moreover, as the "colorblind" approach came to dominate the legal framework of modern crime control, a personal responsibility narrative helped to fill that void. The result, we find, is that blacks as a whole are nearly as likely to turn to failings of black culture in to explain the role of race in criminal justice as they are to consider explanations that hinge on black segregation, racialized poverty, and intentional discrimination" (p. 25).

\section{Local Government}

The interviewed residents had very little praise for local government and its officials. Some of the distrust and negative sentiments of police seemed to influence 
community member perspectives on local politicians and the policies of Louisville Metro Government. My findings were the same as those of Lerman and Weaver (2014), "the sense of the state [learned from criminal justice contact] is one of control, hierarchy, and arbitrary power.... Custodial citizens come to see their political selves as locked into a deeply stigmatized and powerless class" (p.121). However, the same characterizations of police- harassment, abuse, surveillance, social control, and also neglect were also applied to local government through experiences with its social welfare administration, public housing authority, and also, the failure to achieve community economic development that benefitted existing residents.

Residents consistently characterized local government as neglectful at best and malevolent at worst. One black woman Beecher Terrace resident stated her perspective on local government succinctly, "they don't care nothing about these people living in these bricks" Another black woman interviewee agreed there were, "no people to fight for us." The lessons people learned from the carceral state were also taught through other portions of local government that also engaged in practices of punishment and surveillance that characterize the carceral state.

Interviewees articulated their experience of city life as residing at the bottom of a hierarchy based on race, class, and space and also, perceived their position as one of political powerlessness, where they were unable to control the destiny of their community. I found this perspective to be true among all neighborhood residents whether or not they personally experienced contact with the carceral state. The ripple effects of the carceral state on families and friends mattered, as did the community-wide observations of policing in the neighborhood. 
Other state institutions also engaged in practices of surveillance and punishment. Based on the group of individuals I interviewed, particularly in the public housing project, I am unable to distinguish between systematic disadvantage and the carceral state in creating "custodial citizens." Here, space, and particularly the neighborhood in which one resides, is the key indicator of custodial citizenship. Therefore, I read these perceptions of the state as part of a broader urban governance approach, manifested in a number of local government institutions (not just the carceral state) that stigmatize, criminalize, and punish the city's poor. To me, the qualitative data is not just instructive on how custodial citizens envision local government, it is also indicative of the contemporary neoliberal urban governance management of poverty.

The public housing authority registered prominently as an influential local government institution in the lives of Beecher residents. Multiple interviewees talked about the unaddressed maintenance needs in their apartments. Two women in separate interviews noted that they lived without heat in winter and were forced to use their oven to heat their home. In one focus group, two women discussed the practice of home checks where employees from Louisville Metro Housing Authority would perform random inspections of their apartments. If a violation was found, the resident was fined. A participant explained, "If you don't pay that, that means you don't pay your rent because they're not going to accept any of it. You have to pay the fines. Even if you go over and tell them that it wasn't trash in your yard, kids running through putting trash in your yard. Because maintenance doesn't want to clean it up, [they] write it up. That's $\$ 45$." This is an example of public aid and social welfare institutions adopting practices of surveillance and punishment that are traditional hallmarks of the carceral state. 
It also further reinforces the idea of neoliberal urban governance that manages poverty through punishment and control. These mechanisms are designed to enhance the individual responsibility of those who are deemed to lack it because of their class status and their reliance on social benefits from government. Hackworth (2007) argued the marginality of public housing makes it a, "useful vehicle through which to observe the process of neoliberalism" (p. 41). He continues, "In general, while U.S. public housing has never been a comprehensive or completely 'public' system of provision, recent efforts to restructure have demonstrably worsened conditions for current tenants. This restructuring has sought broadly to neoliberalize the public housing system by emphasizing 'individual responsibility' (the 'One Strike and You Are Out' program), the market as social provider (Section 8 housing), and the overall reduction of government oversight (demolition of existing stock, inclusion of private management). The net effect of such changes has been a reduction of housing opportunities paralleled by the expansion of penality for residents" (p. 51).

Another way residents are taught about their political powerlessness in local government is through an acute inability to receive even the most basic of services in one's own community. Trash collection and street cleaning were other local government services flagged as inadequate. As one resident claimed, "look at the trash, go to the Summit, you can eat [out of] the dumpster." Another participant in different focus group expressed the same sentiments, "we need the trash cleaned, and we need lights." An older African American woman agreed with her saying, "sometimes the pool out there floods for weeks and mosquitos come." 
While residents never used the terms voice, decision-making power, and democracy- these are precisely what they were describing with how the carceral state and other local government institutions governed their lives. The carceral state represented one institution in a series of local government offices that contributed to feelings of political powerlessness among residents. Residents articulated how they wanted police to engage with their community, but felt these suggestions went unheeded. Police approached the neighborhood aggressively and made community members feel isolated, contained, and stigmatized. Residents preferred that officers get out of their vehicles, patrol on foot, and get to know community members. Community members felt largely unable to influence policing practices, and this was a primary example of the decisionmaking power and voice Beecher Residents lacked in local government and its institutions.

Another example is the Vision Russell project, administered by the local housing authority, through a program that is the progeny of Hope VI. The website explains, "The Choice Neighborhood Initiative (CNI) is a collaborative effort to create and implement a dynamic and transformative plan for the Russell neighborhood, including the Beecher Terrace public housing development" (Vision Russell, 2018). Residents did not view Vision Russell as a collaborative community project. The plan to raze the Beecher Terrace public housing complex and revamp other portions of the Russell neighborhood reinforced feelings that residents had no voice or decision-making power in the institutions governing their lives. As one older black woman lamented, "there are people that are old, sick, and can't move. They feel comfortable and safe. They are being taken care of by neighbors. This is not a hell place, there are people bringing it here." 
At least two interviewees doubted the effectiveness of the coming revitalization because they had been relocated to Beecher Terrace from another housing development by a previous Hope VI project. A quote from Samara (2012) is instructive on the ways in which removal from housing for economic redevelopment directly implicates citizenship. He writes, "Citizens have lost their citizenship because their position within the networks of urban governance leaves them relatively powerless to enact policies that would allow them to stay... In this process of displacement, a loss of both home space and political space occurs. They remain citizens within the context of the national polity, yet they are without a polity in those spaces in which they actually live. They have the right to remain in the country, but not in their neighborhoods or cities, which is often where inequality is organized" (p.46).

In addition to the carceral state, public housing, government waste management and public services, residents also took away cues as to their own perceived political powerlessness and subjugation from the disinvestment present in their community. The vacant and abandoned houses, the persistent violence, and the lack of places to shop sent signals to residents that local government simply did not care about their community. The descriptions of the built environment generate a key point in regard to space. Herbert and Brown (2006) tied the neoliberal political culture of hyperpunitiveness to criminological theories, such as broken windows policing. These scholars draw a direct line between assumptions about urban spaces of "disorder" to aggressive policing practices. Present in the interviews were descriptions of a visibly deteriorated built environment that seemed to be connected to the identification of the community as a site requiring surveillance. 
Although a series of local government institutions and the built environment contributed to resident perceptions of city government and their neighborhood, interactions with LMPD featured most prominently among these. The fact so many residents associated local government with police, combined with a pervasive distrust of the police, is instructive as to why community members feel disenfranchised within the context of broader city life. Residents were implicitly asking why they could rest assured of persistent contacts with the police and carceral state as part of neighborhood life, yet had difficulty obtaining groceries and other basic resources in their community. Later in this chapter, I will discuss the implication of these perceptions about government on the political participation of residents. However, from the resident's view, police and policing were the one guaranteed form of government services received from the city.

\section{The Impact of the Carceral State on Citizenship in the City}

The constant presence of the carceral state among Beecher Terrace residents shapes all dimensions of the resident's experiences of citizenship in the city- economically, politically, socially, and in terms of mobility. Pervasive carceral state interventions impact residents who may themselves be caught in its grip, and also those who may be bystanders observing encounters with the police or individuals who have family members

ensnared in the criminal justice system. In Beecher Terrace, there exists an added layer of state supervision because the place where residents live is owned, administered, and managed by local government authorities also pursuing policies of surveillance and punishment. 
In what follows I attempt to describe how state surveillance and punishment functions to influence the different dimensions of city citizenship through showing how they exacerbate already precarious financial situations, conscribe access to public space, discourage voice in the political process, and delimit social power for hypersegregated residents through reinforcing racial ideologies. Taken together, the interviews revealed marginalization and limitations imposed on full participation in the life of the city by the carceral state. What follows is a systematic review of the impact of the carceral state on the substantive citizenship experiences in the city among Beecher residents organized around the four frames of citizenship in the city presented in Chapter Two.

\section{Economic}

One outcome of neoliberal urban governance is growing economic inequality within and between cities (Spence, 2015; Weaver, 2016). Narratives from community residents, detailing the impact of the carceral state on their economic standing, reflect the role of the carceral state in reinforcing economic segregation in neighborhoods of concentrated disadvantage. The substantive citizenship experiences of residents point toward the carceral state as an institution that maintains and enhances race and class inequality between neighborhoods. The prevalence of fines and fees assessed for even low-level carceral state contact and the impact of the carceral state on the ability of residents to procure work contribute to the structural inequalities existing in cities along lines of race and class.

Carceral state contact can create a series of economic consequences for the individuals caught in its snares, with ripple effects impacting their family and the larger 
community where these contacts are aggregated. Arrest, even without a conviction or prison incarceration, carries with it a host of financial costs, and many interviewees articulated the financial burdens associated with arrests and criminal convictions for even low-level offenses. Jail fees while incarcerated can multiply; there is an administrative booking fee for being detained in the local jail, a medical co-payment fee for inmates who wish to receive medical attention, and phone calls also generate fees that must be paid by families and loved ones. Referring to the fees assessed for jail incarceration, one interviewee explained, "they gonna charge you an arm and a leg to pay for the place."

Upon arrest, if the low legal standard of probable cause is found, a monetary bail can be assigned, and the defendant or their family must provide the necessary funds to secure their release. Families and friends also tap into already scarce resources to provide funds for inmates to purchase basic toiletries and other items while incarcerated. As one respondent explained, "my girl gotta come spend unnecessary money to get me out and that hurt my kids cause... she had to take the money to come get me out of jail. So it affects not only me but my loved ones and everybody." A number of interviewees remained incarcerated, without conviction, for days, weeks, even or months awaiting the resolution of their cases. One young man in the Russell neighborhood discussed being held in jail on a $\$ 25,000$ bond from January to May, and ultimately pled guilty to be released on a term of probation.

Even low-level offenses can carry with them jail time and a host of fees. One interviewee was incarcerated for two days and assessed a $\$ 180$ fine after pleading guilty to misdemeanor marijuana possession. In response, another young black male respondent said, "to get charged with trespassing is bogus... The justice system gets $\$ 185$," referring 
to the fees assessed for a criminal trespass charge. One woman described her court experiences saying, "it be like 50 people in there and everybody gotta pay court costs. Like everybody gotta pay like $\$ 80$ to $\$ 200$ worth in court costs.” Interviewees also discussed their experiences with being jailed for the failure to pay court-assessed fines and restitution, a national problem addressed in a letter to colleagues sent to jurisdictions nationwide by the Department of Justice in March of 2016. One older gentleman from Beecher Terrace claimed to have told a judge, "I have more time than money," and was subsequently incarcerated for non-payment of fines.

There is a great deal of literature exploring the economic impact of prison incarceration, but very little academic work considers the financial impact of lower-level carceral state contact. Measuring the neighborhood wide economic effect of mass criminalization, in a community where arrests occur almost daily, is an area ripe for and in need of empirical research. One study from DeFina and Hannon (2010) found mass incarceration played a significant role in enhancing county-level child poverty, particularly in counties with larger populations of non-White residents. Much has been written on the effects of prison incarceration for future earnings and the ways felony convictions impact poverty and inequality (Western, 2006). Yet, there is ample room to understand how low-level carceral state involvement, with its associated fines and fees, may enhance poverty for an entire community and maintain existing patterns of racial and economic segregation.

While there is a dearth of academic literature, the Department of Justice Report on Ferguson (2015) detailed how the assessment of fines and fees were used to generate revenues for local government, with dire consequences for policing and the community. 
The DOJ found the aggressive enforcement of low-level offenses in lieu of promoting public safety led to systemic practices of racial discrimination and constitutional violations by police that undermined public trust. In addition, similar to the stories from residents, the assessment of a fine could lead to incarceration for non-payment and substantially impact already precarious financial standing for individuals and their families.

For the respondents in the study, money was perceived as improving outcomes in the criminal justice system, and many interviewees felt that they would not have a favorable resolution to their case if they were represented by a public defender. Interviewees wholly rejected notions of justice, due process, and equal treatment under the law, irrespective of one's economic position in society. This is an example of the tension Marshall (1950) notes between an unequal economic order and the egalitarian principle of citizenship, that one's class status may impede their ability to access other rights equally, such as justice in the courts.

The ubiquity and cost of fines and fees further influenced resident views that the carceral state functions as a revenue generator. Multiple respondents made claims that the entire criminal justice system was connected through creating profits for stakeholders. One respondent explained, "Everybody is in it together. They all working to make some money. It's a chain reaction, the police lock us up, the lawyers get paid, the judge get their end depending on how much they charge for the case, then the prosecutor get cut in, then the jails are getting paid. It's a domino effect."

These stories from residents regarding fines and fees reflected the prevalent idea among community members that government and private industry benefit financially 
from incarceration, and that the carceral state operates, not according to principles of public safety, but to enrich those in power. This is precisely the claim I sought to highlight in the introductory chapter of this study. In addition to social control, the racial practices of the carceral state also generate profits based on the subjugation of black bodies. These perceptions of the profit motive within the carceral state were also related to how community members thought about the function and motivation of the entirety of local government. Residents equated economic power with political power, and argued government was more responsive to the needs of residents in affluent neighborhoods.

Another way the carceral state reifies poverty is through its impact on the procurement of work. One black male interviewee missed a court date and a judge issued a bench warrant (a written order from a judge authorizing the arrest of a person) for his failure to appear in court. The young man did not want to apply for jobs until after the case was resolved. Another young black male respondent with a criminal record explained, "Only job I can get is through a temp agency. Then I am still scared that a temp agency will look me up." A middle-aged black woman discussed her difficulties in finding employment with a misdemeanor disorderly conduct conviction on her record. The job-spatial mismatch prevalent in many cities limits access to work, and the interview data revealed concerns about the lack of jobs available in the neighborhood.

William Julius Wilson (2009) explained that, “over the last four decades, lowskilled African-American males have encountered increasing difficulty gaining access to jobs- even menial jobs paying no more than minimum wage" (p. 65). Further, "the physical and social isolation of minorities living in inner-city areas of concentrated poverty, severely limits the access that poor black men have to informal job networks 
(the casual networks of people or acquaintances who can pass along information about employment prospects)" (Wilson, 2009, p. 74). Carceral state interactions layered on top of structural difficulties to accessing work makes procuring gainful employment even more challenging for these residents.

Findings from the interviews show the multifaceted ways the carceral state becomes a tool in maintaining and enhancing poverty, even without a felony conviction or prison incarceration. The financial impact of the carceral state influenced how residents thought of democracy and local government more widely. Residents felt because they lived in poor neighborhoods they also received a lower quality in government services. Respondents consistently expressed concerns over their ability to provide for their basic needs and the need to remain safe; the majority of interviewees in this study lived on $\$ 10,000$ a year or less. At this income level, residents regularly cited issues with food security. Carceral state contact not only aggravated the difficulties of poverty, it caused government to function as an instrument that enhanced and complicated its effects. The difficulty in gaining employment with a criminal record or community removal during periods of pretrial incarceration, often due to an inability to afford bail, stood as two clear examples from the interviews.

\section{Mobility}

The capacity of the state to remove community members from the landscape influenced the way residents navigated their daily world. In Beecher Terrace, police consistently constrained the ability of residents to move throughout their community without being profiled, stopped and frisked, or questioned. The interviews revealed 
multiple accounts of police interactions limiting the ability of community members to access public and community space. Mobility, and the ability to access public space is a particularly important concept for African Americans. Historically, antebellum laws, Black Codes, and then Jim Crow laws excluded black people from accessing public spaces on the basis of race. It took two Civil Rights Acts, one in 1875 that was struck down in 1883, and the 1964 Act to finally grant African Americans equal access to public accommodations under the law (Higginbotham, 1996).

Recent events in the news highlight the ability to access public space as a continuing issue for African Americans. Two black real estate developers arrested in a Starbucks, a white woman calling police on black people having a barbeque in Oakland's Lake Merritt park, and police being called to a public pool in McKinney, Texas due to the presence of black children are all examples of access to public space being limited on the basis of race (Stewart, 2018; Guzman, 2018; Shorey, 2018).

These perspectives on mobility were particularly salient among young, black men. In a focus group comprised entirely by this under 35 demographic, one respondent claimed police stop him 4 to 5 times a month. In response, a participant pointed at other interviewees and explained, "Me, him, and him walk down the street, they stopping us automatically because we got on hats." The narratives arising from the interviews also highlight the realities of stop and frisk policing and the ways in which young black men in particular frequently encounter the state as a coercive mechanism of social control. Alexander (2010) wrote that, "subjecting people to stops and searches because they live in 'high crime' ghettos cannot be said to be truly race-neutral, given that the ghetto itself was constructed to contain and control groups of people defined by race" (p. 132). 
Even older residents in Beecher Terrace described their own personal experiences with being stopped or followed by police while commuting through the neighborhood on foot. In one focus group of residents aged 52 and older, when one participant said that, "police harass you when sitting in your yard," others agreed saying: "they walk up to you and harass you," and "they don't give a damn." According to residents, officers would say, "You fit the description of a break-in," or "there was just a robbery around the corner" to justify the stop. Some described witnessing groups of young black men being detained by police while walking through the neighborhood and officers asking for their identifications to run their information to look for bench warrants. Community members felt criminalized because of where they lived and how they looked.

Not only was mobility impacted within the neighborhood, but residents also felt surveilled and policed outside of their community because of their race. Residents referred to $4^{\text {th }}$ Street Live, a local entertainment district, as a space where people of color were not welcome. As one black woman interviewee explained, "They made downtown for people that have money. We're lower class. If you go on $4^{\text {th }}$ Street, you have to be dressed a certain way or they will look at you all funny. It's like we don't belong down there."

These impingements on access to public space along lines of race have consequences. David Harris (2002) writes, "Because profiling has such a strong impact on the mobility of those subjected to it- the diminished willingness of minorities to go where they feel they will get undesirable law enforcement attention- these tactics help to reinforce existing segregation in housing and employment." (p. 102). The example of $4^{\text {th }}$ Street Live illustrates Harris' point, that residents felt unwelcome in particular spaces in 
the city. In addition, the entertainment district of $4^{\text {th }}$ Street Live is an example of a neoliberal local government project, created through a public-private partnership using taxpayer dollars through a series of incentives (McAdam, 2012).

At $4^{\text {th }}$ Street Live, police carefully monitor for the appropriate dress code to enter into the area filled with bars and restaurants. This arbitrary race-neutral discretion related to dress was used to exclude black entrants, and the entertainment district has been met with a series of racial discrimination law suits over a period of years (Dickerson, 2015). This is an example of a colorblind racist practice, occurring at a site funded through tax payer dollars that functionally enhance sociospatial inequality.

\section{Political}

The interviews elicited an overwhelming, pervasive feeling of political powerlessness among residents, a ubiquitous distrust of city government officials whose primary imperative was perceived as profit, and a perception of unequal treatment of the community by Louisville Metro Government in its provision of public services, including the way the community was policed. As noted in chapter 3, Wright's (1985) contention that Louisville blacks received inadequate local government services or none at all, and was present in the interviews with African-American residents of Russell almost one hundred years later. While residents looked to a variety of government services to draw these claims, they also most often associated Louisville Metro Government with police. Reflected in stories of police brutality and daily police harassment, police are a primary dimension of the carceral state that profoundly impact the daily, lived experiences of neighborhood residents and influence their outlook on politics and political participation. 
Interviewees consistently expressed feelings of government neglect toward their community and clearly felt government functioned to limit their political possibilities. For example, residents felt they had no voice in determining how their community would be policed as many interviewees wanted officers to exit their patrol cars and walk the streets.

A split along lines of age determined how individuals felt about voting. One younger woman claimed she did not vote because it would not change anything. These sentiments were shared by all of the participants in her focus group who were aged thirtyfive and under. Alternatively, in focus groups with older participants aged fifty and up, they were emphatic about the importance of the vote. For example, in a focus group of seven conducted in October of 2016, when asked if they voted, there was a uniformity of yes among the respondents. One woman exclaimed, "Yes! Yes!" In response, another woman said "Yes, it's a must" while another said "voting is a good thing, you need to vote."

Political participation can be measured in a variety of ways that extends beyond casting a ballot, including attending meetings with government officials. Interviewees consistently expressed that they did not or had only attended one of the community meetings pertaining to the coming revitalization because of their overall experiences with local government. The forgone conclusion that residents would be removed created a great deal of anxiety among interviewees but, residents also found it futile to attend meetings when the decision to revitalize the community and tear down the housing development was already made. Two residents in particular drew these conclusions as a result of their own personal experiences with previous Hope VI redevelopments where 
they were moved from the place where they lived. This is one example of how feelings of pervasive distrust influenced political participation.

Residents did not feel political representatives heeded their perspectives, nor did some of them want to move for redevelopment. A black woman interviewee described the coming redevelopment and the neglect of resident concerns from local government, "Sometimes they will have meetings at Baxter. The last one they had was like a year ago. They really don't check on us as one. They are talking about rebuilding the last one I went to, but other than that, they don't really check on us." There was an overarching feeling that the revitalization was not designed for the residents already living in the community. They felt disenfranchised and believed they were without decision-making power despite government assertions that Vision Russell was a collaborative community program.

We can return to the survey data to attempt to see some measure of the carceral state impact on political participation when it is concentrated in a neighborhood. $32.7 \%$ of residents responded that they did not have the power to change the neighborhood, $45 \%$ responded that they did not volunteer in the community over the past year, $75.5 \%$ had not attended a metro government meeting, and $64 \%$ were not involved with the neighborhood association. Most striking about this data is that most survey-takers saw themselves as having the agency to change their community, a statistic that could be better explored in future research.

It may be that the coercive actions of the police and daily interactions with the carceral state directly impact political participation. The feeling that government officials do not care about the lives of the residents may also arise from the interactions with the 
carceral state and in turn stifles political participation. What is clear is that in the Russell neighborhood resident engagement in politics is low and residents often characterize potential efforts on their part to generate change as futile; a finding that does not bode well for local democracy.

\section{Social}

The social dimension of citizenship in the city highlights the ways residents describe and discuss their community and their neighbors. This is important because it hints at ideological frameworks applied to race, class, and the urban space. Much of the beginning of this chapter addressed the social dimension of citizenship in the city by providing a narrative of how residents thought about their neighborhood and themselves within the broader context of city life. Yet, there are other ways to identify the relationship between social power and standing as a citizen. One is social networks and how life trajectories are impacted by the carceral state, and this section will address these points before providing an extended discussion on how race occupies the social imagination of residents and the implications of it.

The social networks and the social power of residents were limited by heightened and continuous carceral state contacts. For example, one mother in the Russell community that lived in an apartment on the edge of the Beecher complex talked about the impact of her son's incarceration on the family. She described it as a "big hole" in the family because her son would help with childcare and running errands for other family members. In this way, the carceral state impacted social networks through the removal of family and friends from the community. Most often women were left to fill gaps created 
by incarceration of a loved one. The disruption of familial and social networks is another example of how custodial citizenship can become a community-wide phenomenon.

Interviewees who experienced incarceration often expressed that they felt disposable, illustrating the dehumanization involved with carceral state contact. One young man discussed a non-violent gun charge that led to him serving seven years in prison. Another older African American man, incarcerated for two years for child support, talked about feeling forgotten and ignored while serving time in prison, "When I was in prison, I wasn't even a number. I tried to write my Congressman, Alderman... same with everyone in there, you're ignored."

Another way the social fabric of the community was impacted, was through the young age at which carceral state contact began. Particularly among young black male interviewees, carceral state contacts began early, influenced life trajectories, and impacted the overall health of the community. Two interviewees were removed from their home and sent to juvenile boot camps at the ages of 8- and 9-years-old. Also, parents talked about being removed from their families and the inability to provide for their children during periods of incarceration. These are also ways carceral state contact can begin at a young age, even if one is not serving time or attending court themselves. The mother in Russell whose son's incarceration left a gap in the family explained how cycling in and out of jail impacts the ability to function in society. In her words, "now at 35 , they're trying to learn what we learned as teenagers."

The early age of carceral state interventions combined with their impact on social networks sheds light on the ways the carceral state implicates social citizenship i.e., "who is accepted as a worthy, valuable, responsible member of [the] everyday community of 
living and working" (Painter \& Philo, 1995, p. 115). The importance of this point cannot be understated, the interviews reveal a group of people that are considered a "throw away" population, sent to be incarcerated and institutionalized in facilities beginning at a young age. Therefore, not only are residents removed from the community, but also these interventions begin at an early age and impact the children and family members of those who are removed. These early interventions influence the entire trajectory of the community from cycling residents in and out and by altering familial and social networks. Again, direct contact with the carceral state is not required to experience the citizenship effects of the carceral state.

These harsh, punitive state interventions also indicate to residents they are not valued members of the community. One interviewee explained, "Because it's the projects they feel like they better than us. You know what I'm saying? They feel like we have no purpose anyway... Like we ain't nothing. Like that's why we here in the projects. Like we can't become nothing better than this right here. They feel like this is what we gonna be for the rest of our lives. That's how they look at all of us." When one considers the overwhelming number of interviewees in Russell articulating disrespectful treatment at the hands of police, racial stigma stands as a clear reason for such maltreatment, and particularly the history of black dehumanization in America.

The dehumanization of black people was discussed briefly in Chapter 3. Africandescended people have experienced racial stigma since the founding of the country (Higginbotham, 1996). Further, the carceral state has long mediated the relationship between black populations and full citizenship. This long history is another reason why simply using a racial motivation approach to understanding the carceral state fails to 
adequately capture why since the 1970s it has proliferated so rapidly. I would suggest that race, and particularly race attached to class and space i.e., a predominately black housing project is also proxy for group that is in effect, a class of dispossessed workers in an unequal political economy (Websdale, 2001). I do not intend to say that race is a classification that denotes economic class but, rather that race is another structural element that is part of a hierarchical organization of the political economy.

\section{Russell, the Carceral State, and Race}

So much has been written on race and the carceral state, it seems there is little to contribute to the conversation that is new and innovative. The interviews presented in this chapter illustrate a poor African American community targeted by heightened police surveillance as institutional policy and individual officers that exercise their authority in dehumanizing ways against residents. It seems clear that racism is at work, but what are its contours and how does it maneuver through the carceral state to incarcerate black people at such staggering rates? What I seek to contribute to the conversation is a bit of nuance and reframing, to complicate the ways in which race is thought of in relationship to the carceral state.

The interviews with Beecher residents illustrate two distinctions that can be made with current debates about racism and the carceral state. First, the carceral state perpetrates the social control of a hypersegregated black community, and further this control mechanism helps achieve economic outcomes. Butler (2017) and Alexander (2010) represent the camp that articulates the carceral state as a mechanism of social control for African Americans and primarily focus on the legal ways the carceral state 
accomplishes this goal. What requires more attention is the understanding the economic role of the carceral state that warehouses workers who have become disposable in the postindustrial economy that generates revenues for both state and private actors. Both functions of the carceral state, social control and the economic role, contribute to maintaining a hierarchy of race and class inequalities.

The second point I seek to make about race and the carceral state is that deconstructing the ideological and structural dimensions of race is significant analytically. Being more nuanced about how racism operates ideologically and in the political economy, as distinct but mutually reinforcing processes, is critical to addressing the systematic racial outcomes of the carceral state. Distinguishing between the ideological and structural dimensions of race highlights the need for a multi-pronged approach that addresses the narratives and frameworks that support a hierarchical and unequal social order.

Murakawa's recent work The First Civil Right complicates racial ideology and describes how postwar racial liberalism positioned racism as an ideology involving individual animus, thus disguising its structural dimensions that are "rooted in specific social practices and pervading relations of political economy and culture" (p. 11). Not only can racial ideology disguise processes in the political economy but, the ideology of postwar racial liberalism, while well-meaning, when processed through institutions that are discriminatory by design, produced the racially disparate phenomenon of mass incarceration.

The ideological element of racism requires a rethinking and reeducation about race in society, and structural racism points to the need for radical institutional reforms and a 
restructuring of the hierarchical political economy. It is critical to think about both dimensions of racism. Without generating changes in institutions, the economy, and also individuals through challenging the widely accepted dominant racial norms of society, the subjugation of poor black people will transform and occur through other vehicles. For example, through proliferating technologies such as facial recognition and algorithms used to determine pretrial release that reflect racial bias. We are on the cusp of moving from the era of mass incarceration to mass surveillance.

Another reason the ideological / structural distinction of race is important is because acknowledging the structural processes of racism can help reveal how racist ideologies about specific groups are similar and produce parallel outcomes. For example, acknowledging the ideologies that attach criminality to blackness and how they are also transposed on brown bodies through narratives about "illegal immigrants" tie together ICE detentions and mass criminalization to illuminate broader structural processes in the political economy that disenfranchise people of color and poor people.

One of these structural processes is the deployment of the carceral state to achieve the social control of racial groups. The interviews reflected policing practices as a form of social control in the black community. The recent images of police officers with militarygrade weapons dressed in riot gear confronting Black Lives Matter protestors represents the pinnacle of this type of social control. On a daily basis however, what tends to remain unseen from the public eye and news media, in the community where the interviewees live, the police constitute something of an occupying force that corrals neighbors and shapes the way they navigate their world. For example, residents talked about not being able to sit on the porch of their own home without being questioned by police. These 
interactions with officers clearly shape where residents will go and when they will go, thus impacting their mobility.

Stop and frisks, officers jumping out of their vehicles to question residents and detain groups of young black men, and the authority of police to arrest and jail community members were all discussed with concern by residents. As one interviewee with her own carceral state experiences explained, "I mean, they not really here to help us. They say they are but they don't, they harass more than they even help." This quote summarizes how many residents felt about the policing of their community. While some officers may have good intentions, overall they participate in the active surveillance of residents whom are all presumed to be suspicious. Racial ideology normalizes these processes, and the curtailments on the mobility of residents is tolerated and justified through narratives that this group of black people, particularly in this space, require supervision.

Multiple threads of the literature can be brought to bear on this point. First, the policing practices that call for arrests for even low-level offenses and operates to manage signs of "disorder" are explicitly neoliberal in orientation. Under the logic of neoliberalism, spaces of disorder require heightened surveillance and state interventions. The connection with colorblind racism and neoliberalism is observable here because spaces that are considered to be spaces of disorder are commonly racialized.

In Beecher Terrace, social constructions of the space among residents is no different from pervasive ideas attached to the idea of the "ghetto" that is vibrant in the American political and social imagination (see, Cashin 2004). Residents were attuned to dominant narratives about the neighborhood and the people who inhabit it. This stereotyping of the public housing project and its people serves as a justification for heightened police 
presence and round-up style policing, because everyone in the community becomes a suspect by virtue of living in the neighborhood. The fact space becomes proxy for suspicion also supports my contention that custodial citizenship is highly predicated on the space where one lives, and its attendant experiences are not just a result of direct carceral state contact. Residents attached this stereotyping by police to race, and young black men consistently discussed feeling perceived as drug dealers and gang members. As one interviewee explained, "[They] always do more harassing in the projects cause we black."

Residents also discussed the coming revitalization within the context of race. A sizeable number of residents said the revitalization of the community resulted from the desire of the city's white residents to move to be closer to the central business district and downtown attractions. Here we see how Martha Mahoney’s (1994) work becomes relevant. Black hypersegregation resulting from state, federal, and local policies comes to be understood as a natural ordering of city space, and it is reflected in the language of the interviewees. For example, residents talked about the housing project as a black community space, whereas $4^{\text {th }}$ street live and the East End are perceived to be white community spaces.

In this way, racial ideology performs a "masking function," one that detracts from the overall, hierarchical discriminatory design of the political economy. I think of the young black men who were interviewed for this study, most of whom were unemployed, as a racialized discarded worker class. When the focus is on the criminality of blackness or the social control of black people based on racial animus, we miss a conversation about the organization of the capitalist economy. A singular focus on race distracts from 
acknowledging the ways white supremacy has functioned to subjugate black labor through state apparatuses as part of the inherent design of the American political economy created at its birth. Ideas about the undeserving poor and social ideas that the urban poor maintain a "different" set of values are racially-coded frameworks that explain away racialized segregation as individual choice rather than a racialized political economy. Martha Mahoney (1994) explains, "The segregated world we inhabit comes to define race for its inhabitants. The lived experience of people in a segregated society links the perceived natural quality of the world we inhabit with its racialized characteristics- giving the social construction of race a quality that seems both natural and inevitable" (p. 1659). There is nothing natural and normal about the corralling of black bodies into a public housing project. Hypersegregation is the manifestation of government policy colliding with the political economic organization of the society is discriminatory by design.

I also attach the racialized justifications of surveillance and state punishment to the neoliberal emphasis on individual responsibility that informs policy-making for the poor. An individual responsibility perspective on poverty is heightened where black bodies are concerned and informs much of the policy toward the urban poor. Racial ideology justifies disproportionate punitive carceral state interventions and social welfare surveillance. The dehumanizing experiences of the residents are tolerated by a society that understands blackness as deviant and criminal in its popular imagination. Imani Perry (2011) wrote how racial practices of surveillance and punishment are a key mechanism by which racial inequality is practiced in society. Recall Perry’s (2011) assertion that, "Racialized practices of surveillance, leading to a loss of the right of 
privacy is justified through racial narratives about social disorder, invasion, and moral decay" (p. 86).

The process of dehumanization is another area where I identify race as a key ideological tenet of racial thinking that plays a role in carceral state interventions. Many of the residents described their treatment at the hands of the carceral state as one that stripped them of their dignity as human beings. Physical violence and abuse, whether experienced or observed, signaled to all individuals in the community that they existed at the bottom of the social and political hierarchy in the city. Not only this, but some of the things officers said to residents and how they were treated made them feel they were treated as less than human beings.

\section{Conclusion}

This chapter sought to describe the experiences of Beecher residents with the carceral state and the ways it shaped their perceptions of local government and their substantive citizenship experiences. In reading the narratives to understand the role of race, we are able to see it has both an ideological function and a structural one that perpetuates racism through a series of institutions. The next chapter reviews interviews with residents of Portland and concludes by seeking to further unpack the relationship between race, class, and the carceral state. 


\title{
CHAPTER SIX: COMPLICATING RACE AND THE CARCERAL STATE
}

\author{
"Discrimination based on race disguises the more subtle though hardly less pernicious class-based \\ disadvantage suffered by many whites." - Derrick Bell
}

A key contribution of this research project is to nuance existing literature positing the carceral state explosion as a race or class phenomenon and to better understand the intersection between the two. To complicate current analyses of the carceral state, I interviewed black and white residents in two Louisville neighborhoods marked by concentrated poverty that are also located in the city center within close proximity to each other. In the predominately white and poor Portland community, the narratives and data revealed that the experiences of Portland residents with the carceral state are incredibly similar to those of the Russell community. Many of the poor white residents of Portland feel very much like custodial citizens in their own community but, interviews with two middle class, college-educated whites living in Portland nuanced these findings along class lines.

Both black and white interviewees in Portland described a world similar to Russell where carceral state contact was prolific but access to resources and amenities in their neighborhood were limited. These findings indicate that class matters, and that the citizenship experiences people have in relationship to the carceral state are most profoundly shaped by their economic standing. The interview results indicate that poor whites are not simply collateral damage to a racist system of mass incarceration and 
criminalization but are also disenfranchised because of their poverty, concentrated in space.

There existed numerous similarities in carceral state experiences and perceptions of local government among interviewees in Portland. Portland residents frequently expressed their sentiments in language that was almost verbatim to that of Russell residents. The commonalities between the two neighborhoods included overwhelmingly negative perceptions of the community associated with poverty and drug activity, a persistent belief that both police and the broader local government were non-responsive to resident concerns, and a feeling that the criminal justice system focused on generating revenues instead of public safety. Those who experienced carceral state contact directly told parallel stories to that of Beecher residents, but the ways they understood and articulated the cause of their contact varied along lines of race and class. White interviewees never invoked their race, and this omission lends itself to the idea that whiteness is invisible and not thought of as a racial category, an idea that will be addressed later in the chapter.

The findings between Portland and Russell were largely indistinguishable, save for a few differences that will be noted in relationship to how they further nuance the carceral state race and class discussion. In the Portland community, 17 interviewees identified as white, 15 identified as African American, and 1 identified as bi-racial. This presented the opportunity, albeit limited, to consider racial differences in how the carceral state shapes experiences of citizenship in the city. I will not go so far as to claim that the interviews allow me to make definitive, generalizable claims, but they do identify a series of themes that complicate the racial motivation perspective of the carceral state. 
This chapter first provides a background to the Portland community through a combination of observations and a discussion of arrest and survey data before moving into a systematic discussion of the interviews. In the previous chapter, the findings from the Russell neighborhood interviews were organized around the research questions and were articulated and described more meticulously than they will be in this chapter. Because there is so much overlap between the Portland and Russell neighborhoods, in this chapter the qualitative data themes are discussed in turn more briefly. The chapter pays greater attention to how the interview responses help identify the intersections between race, class, and the carceral state. The chapter primarily seeks to identify differences and similarities in carceral state experiences along lines of race and to use these to attempt to consider the impact of race on substantive citizenship.

\section{The Portland Neighborhood}

As explained in Chapter 3, Portland was once a booming area of commercial activity that began to decline after the Great Flood of 1937 and experienced increased flight from the community as residents left to follow industry. Portland is now undergoing a period of revitalization and redevelopment and the neighborhood looks visibly different from the Beecher Terrace housing development nestled in the middle of the Russell community. Whereas Beecher is a dense public housing complex with narrow streets and closely situated buildings, Portland is comprised of older housing stock and historic buildings. There are about 500 fewer residents in the Portland census tract and fewer family households as well. While the majority of residents in the tract are renters, approximately 
$56 \%$, they are largely housed in single-family homes or in homes that have been converted to apartments.

While Portland looks different, it is analogous to Beecher along lines of class, but Portland is not nearly as poor as the census tract of Russell/Beecher. According to 2015 ACS estimates, $23.2 \%$ of Portland residents made an income of $\$ 9,999$ or less, and in Beecher this number doubles to over $40 \%$ of the population. The neighborhoods, however, maintain similar education and employment demographics among the residents. A little fewer than $30 \%$ of residents in both communities possess less than a high school diploma, and $48 \%$ of the population in both neighborhoods aged 16 and older were in the labor force. Portland was chosen for this study because of its majority white demographics, combined with the concentration of poverty, and its proximity to the downtown business district in Louisville, Kentucky. Of note, however, is that there were no white neighborhoods with levels of poverty as measured by household income, even remotely approaching the concentrated poverty found in the census tract housing Beecher Terrace. The racial disparities noticeable in the intensity and depth of poverty between predominately black and white neighborhoods helps support my contention that the political economy consistently generates disproportionate racial outcomes as part of the structural ordering of the political economy.

Respondents in Portland regularly expressed concerns for their safety due to the prevalence of violence and drug activity. Portland was one of ten neighborhoods accounting for over half of the violent crimes in the city in 2014. Eight of the Portland residents interviewed for the study lived in the community their entire lives and observed changes in the neighborhood over time. Another subsection of interviewees were 
longtime residents who lived in Portland anywhere from 5 to over 20 years and many of them also described the neighborhood as undergoing a decline, with the drug activity and violence in their community worsening. Resident interviewees moving to the neighborhood only in recent years or months also expressed similar concerns. Two middle class, college educated white men interviewees recently moved to the neighborhood to aid in revitalizing the community through work with their church and The Table.

Similar to Beecher, drug activity was consistently cited as a community-wide problem. The qualitative data revealed drug activity and the opioid epidemic dramatically impacted the Portland community. At least three interviewees noted that they lived in close proximity to drug activity. One white woman interviewee said, "[I] think one of them is a meth house next door, I've seen a lot of people doing drug deals. I have no proof to call the police. I would hate to make a phone call if they're not making meth but I see a lot of foot traffic." There existed a near unanimous consent during a focus group conducted at a day program for Portland seniors that police knew where drug houses existed in the community but turned a blind eye to the activity. In one interview with three women of different races (black, white, and biracial), they all agreed the nickname for the community was "Heroine City."

There were positive qualities attributed to the neighborhood as well. One black male interviewee who lived in Portland for a little over a year said he was skeptical about moving to Louisville at first because of the violence but he found Portland to be "pretty decent" and said, "The people are friendly." Other interviewees agreed Portland residents were friendly, and those who were involved with the work of the local neighborhood 
association Portland NOW felt the neighborhood was improving. Many respondents seemed to indicate criminal activity in Portland depended on the specific street block and the residents who inhabited it. Similar to Russell, many longtime residents called Portland "home," despite its many challenges.

\section{Perceptions of local government}

Resident interviewees overwhelmingly expressed similar perceptions of local metro government as ineffective and neglectful of the Portland community. Respondents from Portland often articulated metro council and other government officials as unable to personally relate to the conditions in which residents lived, a sentiment similar to that of Beecher residents. Further there was a general consensus the neighborhood received unequal treatment because the neighborhood was poor. A variety of answers were provided to the question of what Portland residents associated with Louisville Metro Government, including the L\&N building (where social services are distributed), the mayor, and more specifically being "left out" or ignored by the local city government. Multiple respondents even asked, "What do they do?" These responses were incredibly similar to the Russell community and the most pervasive response in both communities was that police constituted the most visible and notable part of local government.

Many residents associated the lack of amenities in their communities with local government neglect. One older white woman believed it was the local metro government's job to bring businesses to the area, but noted they were failing in this endeavor. Similar to Russell, Portland community members felt economically isolated from the rest of the city due to the lack of grocery stores and places to shop and attributed 
the lack of amenities to local government disregard. Residents articulated narratives about local government abandoning their community through comparing Portland and Louisville's West End with more affluent areas in the East End. A 58-year-old African American woman explained, "[we are] left out down here economically. You can drive down the street and see that we're left out. You go to the East End and you see a big difference." A 27- year-old white woman interviewee expressed similar sentiments about disregard from metro government and cited the maintenance of the parks as an example. She explained, "The richer the neighborhood, the more amenities, better policing."

Residents consistently cited the prevalence of abandoned homes as another example of government neglect. As one 37-year-old, college-educated white man explained, “I've seen abandoned homes taken better care of in better neighborhoods. In Portland the grass grows high until the city comes in. The property just looks terrible, buildings are falling apart." Another black male interviewee claimed, "I haven’t seen this many abandoned houses since I left the South Bronx." The ubiquity of abandoned houses were also linked to criminal activity in the neighborhood.

Unequal treatment by local government was consistently attached to the economic standing of the community. One biracial woman believed local government viewed the neighborhood as “just a bunch of poor white folks with nothing to do. They don't have no self-training." Interviewees consistently viewed the poverty of residents as attributable to their own individual personal failings, and felt government developed policies and practices toward their community based on this premise. Many respondents addressed the stigma attached to the Portland neighborhood as a community of poor white people and as the white ghetto. These perceptions crossed lines of race and age, both within Portland 
and in the Russell community. Residents felt stigmatized and stereotyped as deviant because of where they lived and because of the poverty in their neighborhood. I ground this view in the neoliberal strand of thought that considers poverty as the result of individual attributes and attitudes.

\section{The Carceral State in Portland}

The number of survey takers in Portland was much lower than in Russell. 44 respondents completed surveys. Of the 44 respondents, $34 \%$ (16) indicated police stopped them in the previous year. In terms of fairness, $73.3 \%$ (15) felt they were treated fairly by the stop, and this statistic is almost the complete reverse of Beecher where the vast majority of those surveyed felt they were treated unfairly. Later in this chapter I will address this important gap in perception. In Portland $66.7 \%$ of residents indicated that upon being arrested they were able to afford bond to secure their release from jail. Later in this chapter I will address this important gap in perception.

According to the LMPD data 680 arrests took place in Portland in 2015 and 2016, and $78.6 \%$ of arrestees were white. $51 \%$ of arrestees allegedly committed misdemeanors with drug possession being the most prolific type of charge, constituting $38.5 \%$ of arrests. These numbers are similar to Beecher. A slightly higher number of Portland arrests were for felonies but, non-violent property crimes and drug possession constituted the vast majority of arrests in both neighborhoods.

\section{Perceptions of the Police}


There existed a wider variety of perspectives about police in the Portland neighborhood. Some residents believed officers had a difficult job and were simply doing the best work they could considering the circumstances. One African-American male interviewee said the patrolmen in the neighborhood seemed, "pretty nice, they'll drive and wave back. Then I have to consider my age. They think I'm an old man who won't do anything. They seem pretty under control." Another 44-year-old white woman talked about her experiences with incarceration, having been locked up in jail three times, twice at age 33 and once at 34 . According to her, she felt police treated her well and she was able to bond out of jail through assistance provided by her family. She also reported being stopped by police multiple times while walking through the community but did not feel profiled by these encounters and felt officers were properly performing their duties. She lived near a police station and saw "officers every 5 minutes," but felt they should be permitted to "do more" to effectively police the community. This view of officers was in the minority among interviewees.

Some Portland residents believed police tried to perform their work competently, but the vast majority viewed the tactics used by officers as ineffective. Many residents articulated the idea that, similar to local government, officers patrolling the area did not care about the residents of the neighborhood enough to do their job effectively. Again, we see a stigma attached to poverty that implicates the availability of resources and institutional interactions between local government and citizens. One older black woman believed the police were afraid of the neighborhood and this impacted their ability to do their job effectively. In a separate interview a white male agreed with her sentiments, advocating for better training of officers. One elderly white woman reported being 
physically assaulted with no response. According to her the incident, "wasn't enough [for the police] to walk around the corner, in another neighborhood they absolutely would have done something."

Generally speaking, Portland interviewees articulated similar narratives to Russell residents- that local police either failed to respond when called or did not attempt to adequately resolve a situation when they did arrive. These 'they're there when you don't need them and nowhere to be found when you do' sentiments were articulated by black and white interviewees of all ages. One white woman respondent explained, "My mom called the cops about a lawnmower that was stolen, and it took about an hour to get there. They said, 'we'll do our best,' and took the serial numbers and we haven't heard anything since."

The aggressive nature of policing practices also concerned Portland residents. A surprising number of respondents expressed anxieties about the frequency of high-speed chases in their neighborhood because of the danger they posed to community members and particularly children. Residents saw themselves as custodial citizens based upon the community where they lived, and this was true among interviews without their own direct carceral state contact. In both Russell and Portland, escalated policing tactics impact the well-being of all residents, whether or not they are engaged in criminal activity or were personally the target of carceral state interventions. Also similar to Russell, the ubiquitous carceral state presence in Portland impedes the ability of residents to move throughout the community unrestricted. Residents feel surveilled and rendered suspicious by virtue of living in the neighborhood. 
Many respondents witnessed the police pull people over and search them or their vehicles or experienced this type of treatment themselves. One white woman interviewee described her own dissatisfaction with officers, saying she was stopped while walking down the street and was asked for her identification. She said officers told her to shut up and felt police talked to her inappropriately. A black male interviewee said he sees police stop people on the street in the community every day and attributed the heightened police presence to the drug activity in the community.

One distinct difference between Portland and Russell, however, was the level of violence perpetrated against residents by police. In Beecher, a number of interviewees reported seeing officers physically abusing people, whether through kicking, punching, or a display of their weapons. None of the Portland interviewees mentioned these types of interactions, and none expressed concerns about the level of force used against community members, with the exception of high-speed police chases. Recalling the survey data, the majority of those surveyed in Portland felt they were treated fairly in their encounters with police. The racial motivation view of the carceral state identifies points of discretion in the criminal justice system where racial bias exists. In this vein, it seems that policing is one area where racial bias can be viewed, specifically around the level of brutality experienced by residents. I highlight this as an area where race matters, particularly ideologically, and theorize that this disparate treatment as part of the process of dehumanizing black bodies that is a hallmark of racial thought.

Access to Financial Resources. 
The way Portland residents described their carceral state experiences was predicated on their ability to access to financial resources. For example, one Portland resident, an African American woman, reported her felony conviction did not affect her employment opportunities, because her employers at the time helped her defend herself in the case. The 44-year-old white woman who experienced incarceration three different times in the previous decade, talked about being able to bond out after arrests because her family resources allowed her to do so.

A black male interviewee said, "The main difference" in criminal justice outcomes relied on "whether you have money and if you know people." These perceptions of the carceral state crossed racial lines among interviewees and were also applied to other courts aside from criminal. Numerous women interviewees talked about their experiences with family court, and one woman said she was told that the process would move faster if she could afford a paid attorney. Portland residents also perceived the carceral state as rationing out justice to those who could afford to pay for it, a sentiment also ubiquitous among Russell interviewees.

Class is the consistent thread between the two communities, and the abundant similarities between the narratives of members in both communities helps illustrate how economic class, combined with carceral state contact, shape life in the city politically, economically, socially, and in terms of mobility. For example, two men, one black from Russell and one white who lived in Portland, both of whom experienced prison incarceration described their experiences with reentry along the same lines. They discussed the economic setbacks associated with prison incarceration and the difficulties 
with remaining connected with family members while incarcerated. Both also highlighted their inability to procure good paying jobs as convicted felons.

\section{Political Participation}

Political participation can be measured in a variety of ways: voting, attending community meetings, and engaging neighbors on matters of policy that impact the community. Some people who had previously experienced carceral state contact participated in their community through volunteerism. One black woman who was a grandmother and also a convicted felon volunteered her time and also helped share information with other residents about resources in the community. This is yet another example of the supportive networks women create. Also, the fact the interviews took place at The Table and the Neighborhood House impacted these findings because interviewees were most often connected to those institutions through volunteering or attending meetings. The anecdote of the woman with a felony conviction demonstrates, however, that some community residents, despite their own carceral state contact and their own beliefs about the ineffectiveness of local government, still attempt to be civically engaged on some level through supporting their neighbors.

Interviewees communicated mixed feelings about the local neighborhood association "Portland NOW". One African American woman explained, "they should change their name to Portland Then.... That was the way I felt. They want to keep it how it is. They don't want any houses to be demolished [or] changed and put up a different building that would look different from the rest of the neighborhood." Another elderly African American male spoke more positively about Portland Now describing it as an 
organization concerned with revitalization and other community issues like transportation. Participation in neighborhood organizations, such as the Table and Neighborhood House represented one primary way interviewees engaged other residents.

As mentioned, one African American grandmother responsible for raising her grandchildren was a convicted felon who could not vote due to Kentucky law. Despite her inability to participate in her community through voting, she attends meetings for grandparents and Metro United Way sponsored events and shares information with people who need help. As she explained, "there was a guy who needed help and I sent him to the Neighborhood Place and they've been helping him.” This seems to be a consistent theme in the way that black women in particular utilize and maintain social networks.

A white woman talked about neighbors on her block banding together to monitor crime and to stop criminal activity. She explained, "We had the same problem with people hanging on the block and demanded that the police, police the area. The whole neighborhood got involved. We got together with police and got rid of that mess." This story indicates that residents do band together to exercise political power, and to influence the institutions that govern their community. The collusion of residents to procure heightened police presence is also interesting, particularly when the criticisms of how police perform their work was so prevalent among interviewees. This same woman who talked about asking police to intervene with increased foot traffic on her street was the same woman who identified racial disparities in the criminal justice system as a result of her black grandson's arrest. Also, the work of neighbors to gain increased police 
presence is reminiscent of Fortner's (2015) argument that working- and middle-class individuals see the carceral state as a mechanism to protect their property.

The interviews with two college-educated white men who lived in the neighborhood are worthy of note. One white male who worked at The Table talked about being in the community with a group of young, predominately white volunteers and being stopped by police who asked what they were doing walking around the neighborhood because they did not seem like they "belonged" in the community. Neither of them had experiences in the community similar to those expressed by people of a lower income and educational status, but they also seemed acutely aware of their economic and racial privilege. The older of the two white men was a pastor who was familiar with The New Jim Crow and he acknowledged and understood the disproportionate impact of mass incarceration on people of color, even though he was not personally impacted. These men also did not have issues with food security and talked about political power differently than other interviewees. In fact, these middle class white men moved to Portland precisely because they felt they had the agency to help develop the community for the current residents as opposed to outside developers who presented the possibility of future gentrification.

The survey data regarding political participation in Portland was quite similar to the findings in Beecher. 38\% of respondents did not feel they had the power to change their neighborhood, $34.1 \%$ had not volunteered in the previous year, $89.1 \%$ had not attended a metro government meeting, and $60.5 \%$ did not attend a neighborhood association meeting over the prior year. As mentioned, these numbers are not 
substantially different from Beecher. One primary limitation to this study is not having more affluent neighborhoods with which to compare political participation.

\section{Parsing through race, class, and the carceral state}

White Portland residents rarely discussed their social or political world in racial terms. The omission of framing the world along lines of race points to the invisibility of whiteness. As Frankenberg (1993) notes, whiteness involves a set of cultural practices that are usually unmarked and unnamed. The interviews reveal a lack of racial framing because white residents simply did not discuss the social phenomena of race without probing, nor do they identify themselves as a racial group. Here, we can see one way that racial ideology operates because whites are able to view themselves as differentiated from people of color.

I argue the differentiation between raced and "non-raced" groups of people disguises the economic processes that disenfranchise people of all racial classifications, including whites. Further, the omission of whiteness or racial thinking from the analysis of the white interviewees, particularly in relationship to themselves, reflects the notion that to be white is to be situated at the top of a racial hierarchy and all other groups are understood in relationship to the dominant group. Feagin (2013) explains that the dominant frame in American society is the white racial frame that, "has long legitimated, rationalized, and shaped racial oppression and inequality in this country" (p. $\mathrm{x})$.

Yet, the story of Portland residents is more complicated than a simple analysis of white privilege, the invisibility of whiteness, and the dominance of whiteness as a 
dominant racial frame. Although the characteristic of invisibility persists, the material conditions of their lives lead white residents to feel as politically powerless as their African American counterparts. This is reflected in the interviews in two ways. First, through the explicit articulations found among poor white interviewees that their economic standing impacted the resources and nature of policing in their neighborhoods. Secondly, the juxtaposition between the sentiments of poor whites and two middle class white males illustrates intra-racial class differences. These two interviewees recently moved to the neighborhood to aid in revitalizing the community through work with their church and The Table. They did not describe their world in terms of political powerlessness. In fact, both of these interviewees intentionally moved to the community to be a force for good.

In the same way that blackness is not monolithic, so it is true of whiteness. Housel (2009) illustrates this point, "although privilege is related to whiteness, not all individuals marked by white skin color have access to the benefits of whiteness. John Hartigan (1999) has argued this point through his detailed anthropological studies of marginalized whites labeled 'rednecks,' 'hillbillies,' and 'white trash' who are outside of mainstream constructions of whiteness with its incumbent privileges. As the discussion at the beginning of this chapter indicates, poor whites in Portland have similar carceral state contact and neighborhood experiences to poor black residents. These similarities indicate that class matters. Without an analysis of economic class, we cannot fully understand the impact of the carceral state on substantive citizenship because punitive and surveilling government interventions are targeted toward the poor, irrespective of their race. 
Only a small number of studies identified by the researcher address the racial dynamics between neighborhoods with similar socio-economic statuses and different racial demographics. These studies also primarily rely on a criminological approach to understand carceral state contact and focus on police contact rather than the broader array of surveillance and punishment mechanisms deployed by the state. Carr, Napolitano, and Keating (2007) studied three high-crime neighborhoods in Philadelphia, one predominately white, another predominately Latino, and a third predominately African American. Their analysis of interviews with 147 youths concluded that no huge variations existed along race, gender, or age lines and found that all of the young interviewees were negatively disposed to police. Brunson and Weitzer (2009) also studied police-citizen relations among youths but found race did make, "a difference in how youth were treated by police and in their perceptions of the officer" (p. 879). These studies only provide a limited frame from which to assess the function and role of race within the context of the carceral state.

My reading of the interview data is that the similarities in the carceral state (and neighborhood) experiences arise primarily from class because this most profoundly impacts the material lives of residents. Economic citizenship impacts their ability to access resources and amenities. But, where one resides in the city and how place influences carceral state contact is also influenced by race both ideologically and structurally.

Portland residents experienced curtailments on mobility through being stopped while moving through the community and had the same economic and familial difficulties arise from incarceration. Residents talked about seeing people stopped by 
police in the community and also being stopped by police officers themselves, including white women interviewees as well. Although, it is of note that Portland survey-takers were more likely to feel that they were treated fairly during the course of these state interventions. It is difficult, however, with the limited survey and LMPD data and the limited number of white interviewees to ascertain if there is a clear racial bias in the stops being made. Previous LMPD studies showed that blacks were more likely to be searched by police during a vehicle stop (Novelly, 2017). What the interview findings seems to indicate, however, is that both race and class matter in generating mass criminalization.

Without prompting one white woman interviewee married to an African American man said that black people received more disparate treatment from the criminal justice system. She explained, "My grandson is considered black, he is being treated unfairly. My grandson had to stay in until we had $\$ 10,000$ to get him out." Studies also show there is an element of truth to this grandmother's assessment that African Americans are more likely to receive lengthier sentences than similarly situated whites (Alexander, 2010). Whether it is explicit racial animus or a function of implicit bias, studies show numerous criminal justice actors with discretionary power do make decisions leading to racially biased outcomes (Alexander, 2010).

The same way residents felt they were treated in carceral state encounters was related to the entirety of local government. Both black and white residents talked about government neglect, felt equally disempowered politically, lamented the lack of amenities available to them, and also detailed comparable experiences with the carceral state. Here, I do agree with Lerman and Weaver (2014) and also, Clear (2007) who find that people who have direct experiences with the carceral state, and when incarceration is 
ubiquitous in a community, people view the state as an instrument of coercion and control.

These findings push back against the racial motivation camp and the idea that whites are collateral damage. I would contend that whites are victims to the same economic systems and the same hierarchical political economy that is also structured along lines of race. The findings from the interviews seem to indicate that neoliberalism involves a strand of ideology that views government interventions into the lives of the poor as acceptable and justified, and these policies target individuals situated at the bottom of the economic hierarchy regardless of race. However, race matters because it is part of the structural organization of society and provides ideological justification for a system that is viewed as managing the "black threat." In this way, race hides the gap of what are unequal divisions in the political economy.

Race and Space in the Urban Social Imagination

Portland was often referred to as the "white ghetto" and many resident interviewees acknowledged the community as part of the larger West End- a stigmatized, disproportionately poor and disproportionately black part of the city. In terms of thinking about race, the descriptions of Portland as the "white" ghetto, with the racial qualifier added by both black and white respondents was most notable. First, it was the only time whites consistently invoked race in their interviews. For me, this qualifier is a signal about poverty and the idea that poverty is ideologically positioned as an issue that impacts primarily people of color. The distinct racial reference in the case of Portland lends itself to the idea that racial divisions manifested in the spatial arrangements of cities 
are perceived as natural and normal, as Mahoney (1994) described. Take for example how compared to other respondents young black males in Beecher Terrace uniquely described carceral state interactions as a "way of life," as if it was at natural and normal ordering of their world. Not only that, but that the spatial arrangements of black residents are equated with poverty and blackness as a social idea is equated with poverty. Wacquant (2002) further explains the social implications of hyperpolicing in disenfranchised spaces when he writes the, "adjoining of [the] carceral state and hyperghetto, remould the social meaning and significance of 'race' in accordance with the dictates of the deregulated economy and the post-Keynesian state" (p. 55).

Interviewees distinguished Portland from other areas of concentrated poverty in the city, precisely because of its predominately white racial demographics. In my analysis, the descriptions of the neighborhood indicate that the urban ghetto is non-white by expectation and is associated with people of color in the social imagination of city dwellers. These qualifiers regarding race and space position racial segregation solely as the result of racial dynamics instead of the racially disparate functioning of the political economy. To me, this highlights the ideological dimension of race. Rather than pinpointing the specific discriminatory government and private industry practices leading to the existence of hypersegregation i.e. structural racism being deployed by institutions, residents view race as the primary frame for understanding poor communities. Whiteness and poverty are understood ideologically as almost antithetical concepts and discussed as an aberration to the natural social order.

The spatialization of racial inequality in cities is what makes a consideration of geography, and more specifically neighborhoods, a key frame for understanding the vast 
expansion of the carceral sate. Neighborhoods of concentrated poverty contribute most dramatically to carceral state growth because these communities often endure the most aggressive policing tactics. In addition, the urban space is where we can visibly see the disparate impact of racism in institutions and in the economy manifested as hypersegregation. Sampson wrote, "The grip of neighborhood inequality... is amplified, more durable, and qualitatively distinct in the black community" (27). For me, this quote highlights the racism that is structurally part of the political economy. Even in choosing neighborhoods for this study there were no white neighborhoods that were even comparably as poor as black neighborhoods. Overall, the similarities in experience between poor black and white residents living in concentrated poverty points to the need for a more nuanced conversation about race.

\section{Race and the Carceral State}

I have attempted to parse through why the carceral state expansion is not entirely a racial project but is supported by racial ideology. I also sought to show how political economic processes contribute to mass criminalization but have racially disparate outcomes embedded within them. This is where I find the current literature falls short in its either/or characterizations of the carceral state, it fails to be nuanced enough and acknowledge the tandem of ideology and structures. In the next and final chapter I take a step back from reviewing the data and conclude by highlighting a series of ways this project seeks to contribute to and complicate existing literature. 


\section{CHAPTER SEVEN: CONCLUSIONS}

"You are not a citizen of a democracy but the subject of a carceral state, just waiting to be cataloged"Sonia Sotomayor

Justice Sotomayor's words encapsulate the way poor residents of Portland, Russell, and Beecher Terrace described their lives in the city. The vast majority of residents in these communities feel ignored by political leaders, surveilled by police and social welfare agencies, and subjected to local government penalties and punishments at every turn. They cannot truly be referred to as custodial citizens because the substance of their lives hardly makes "citizen" seem like an appropriate term. At least not in their neighborhoods of residence where carceral state interventions are a constant. The primary question posed at the outset of this research was: in mass criminalized city neighborhoods, what are the consequences of mass criminalization for citizenship along lines of race and class, and what can those impacts teach us about local government?

This research project sought to bring the big picture of the carceral state's capacity to surveil and punish to the micro-level in order to understand its real-world repercussions for everyday people living city life. It attempted to tie the political world of local government and governance to the daily urban social world to unpack how residents experience substantive citizenship in disenfranchised spaces. Finally, through a comparison of the experiences of poor black and white residents, the project pursued a 
clearer understanding of how race and class account for the expansion of the massive carceral state explosion and shape its outcomes.

In this concluding chapter, I focus on the research project's contribution to the literature on custodial citizenship and neoliberal urban governance and complicate the conversation on the intersection between race and class. First, I nuance the term “custodial citizenship," and depart from Lerman and Weaver's (2014) claim that this form of citizenship is confined to individuals with direct carceral state contact. They found the experiences of people living in disadvantage are distinguishable from custodial citizens with direct carceral state experiences.

My research shows that space is a key dimension required to fully understand the concept of custodial citizenship. The concentration of punitive state interventions has ripple effects on families and the broader community. One need not experience their own personal carceral state contact as the stories of interviewees whose lives were upended by the incarceration of a family member shows. Women who feared for their son's safety because their child was previously stopped by police also experience the impacts of neighborhood mass criminalization because, for these young men police contact is a part of daily life.

All community members observe the hyperpolicing of their neighborhood. Witnessing high speed chases, hearing helicopters fly overhead, having their streets barricaded by police, all of these and more contribute to neighborhood-wide stigma for all residents. It is the epitome of mass criminalization generated through persistent punitive interventions by state agents on a wholesale neighborhood scale. These indirect 
experiences with the state, primarily due to the concentration of the carceral state at the community level, generate feelings of custodial citizenship.

After nuancing Lerman and Weaver's notion of custodial citizenship, this chapter then moves to other key findings related to neoliberalism in local government. I will discuss why dialogue on neoliberal urban governance requires attention to local carceral state institutions. Even in urban government institutions neoliberalism takes a laissezfaire market approach to promote capital investment and economic development while carrying out punitive, surveilling measures against the poor. One neoliberal policy development worthy of discussion is the transformation of local police departments and how they police the urban poor. In addition, neoliberalism impacts urban governance through interlocking government institutions engaging in the constant surveillance of the urban poor. The interviews with residents illustrate the impact of local neoliberal urban government policy from the perspective of those who most profoundly experience government through punishment and surveillance.

Finally, this conclusory chapter complicates the assertion that mass criminalization results from racism and the intentional targeting of black people on the basis of race for the purpose of social control. Here, I highlight the intersection between race, class, and gender, and parse through the ideological and structural dimensions of racism that the literature largely neglects to distinguish. Viewing the carceral state explosion through a paradigm of race or class without considering their interconnectedness diminishes the ability to understand how both racial ideology and a racialized political economy shape American life. Mass criminalization is not solely for 
the social control of African-Americans, it also performs economic functions that ensnare whites and people of other races from lower economic classes.

The chapter concludes with a call for the radical rethinking of democracy in urban spaces and proposes that rolling back the carceral state requires revisiting Lefebvre's (1967) concept of the right to the city. Participatory democracy, where resident engagement and input occurs not as a perfunctory formality, but as a starting point for creating policy guided by community members is the call I attempt to outline at the conclusion of this chapter. Rather than capital and the free-market system dominating local government in ways that leads to order maintenance policing and fines and fees assessments to fund government functions, public safety solutions should be guided by residents who are currently marked for surveillance and stigmatized. Residents should have a right to the city.

\section{Custodial Citizenship in the Urban Space}

For residents living in concentrated poverty the carceral state acts as the primary mediator of local government. It is arguable that the carceral state is at the heart of city government because criminal justice institutions most often constitute the greatest expenditures in city budgets. Metro Louisville is no exception, over the half of the budget is allotted for public safety and goes to LMPD and the city's jail (Kentuckians for the Commonwealth, 2017). A finding articulated by Lerman and Weaver (2014), is that for custodial citizens the most proximate experience of government is the carceral state. Among interviewees, interactions with the police, the courts, and the local jail were the 
most visible, impactful and frequent engagements with local government and its agents. The poverty level of the vast majority of interviewees also made social welfare agencies another influential local government institution in their lives, and from their perspective, not on benevolent terms.

The neighborhood where one lives influences the type, ubiquity, and descriptions of contact with the carceral state among all residents, even community members without their own direct carceral state contact. Living in government housing where a citation may be issued for garbage being in your yard combined with seeing police brutalize people right outside your door teaches disheartening lessons about local government and democracy. Also, there is almost no way to avoid interactions with police in these neighborhoods, they are a constant presence and almost all of the residents had been stopped or approached even while sitting on their own porch at least once. When space and particularly the race and class demographics of an urban neighborhood are brought into the frame of analysis, it is nearly impossible to distinguish custodial citizenship from systematic disadvantage- they are synonymous.

The interview narratives highlighted stop and frisk policing practices and largely negative interactions with local police. As a result, most of the interviewed residents did not feel like equal citizens in the city and did not see themselves as having substantial political or decision-making power to control the destiny of their community. Here we can recall the findings of Burch (2013), that the concentration of criminal justice contact at the community level can impede political participation. While this dissertation does not discuss it empirically, the hopelessness surrounding prospects for political change and therefore political engagement was a consistent thread in the interviews. 
Yet another lesson residents learn about democracy and the substance of their citizenship in the city is that they come to understand they lack equal standing and less political sway than their more affluent counterparts. The research of Lerman and Weaver support this finding, they write, "Custodial citizens are constituted not as participatory members of the democratic polity, but as disciplined subjects of the carceral state; they are objectified and dependent rather than equal participant" (p. 111). Take for instance, how residents felt about the policing practices in their communities. The interviews revealed constituents that wanted less brutality and harassment, more respectful treatment, officers that were responsive and patrolled more on foot. Yet, residents felt powerless to control the practices of state authorities in their own communities. The relationship with the officers in their communities was unequal and oppressive, and officers wielded power over residents and not with residents to resolve issues of crime and violence.

In interviews, no other local government institution was invoked more than the Louisville Metro Police Department. Similar to the findings of Lerman and Weaver, consistent interactions with state authorities having the capacity to discipline and punish teach lessons about local government and democracy to community members. It teaches them their place as citizens in the city is one that requires constant surveillance, containment, and discipline. Residents learn this because of the community-wide presence of the carceral state, not just because they have personally been stopped and arrested. Negative experiences with officers, or even observations of coercive interactions with residents, reinforce to community members that they are a stereotyped, stigmatized 
group. While it is not an empirical finding, if city residents feel their government views them as deviant, then would it not in turn negatively impact their civic engagement?

Residents believed local government neglected their neighborhood at best and acted malevolently at worst. Many of these lessons were learned from direct carceral state contact, but they were also learned from observations of police activity in their community and by having family members, friends, and neighbors experience surveillance and punishment. The daily consistency of carceral state contact in the neighborhoods for this study reveals entire communities under siege, making space a key element to understanding custodial citizenship. For young black males in Beecher Terrace in particular, carceral state contact was viewed as an inevitable part of life growing up in the projects.

The lessons of stigma and containment also arise from the built environment of the neighborhood where people live and its concentrated poverty; again, space matters. Looking from the bottom up, the urban poor felt relegated to a lower status in the citysomething short of a full citizen with a right to the city. For example, multiple interviewees talked about local government failures to maintain a clean, safe city space for residents through trash pick-up and mowing the grass in public spaces. Some respondents felt unwelcomed in certain spaces including shops in the more affluent east end and the entertainment district $4^{\text {th }}$ Street Live. Residents not only wanted changes to policing to feel safer in the neighborhood, but also access to amenities like grocery stores, clean parks, and good-paying jobs.

This series of negative interactions with the built environment contributed to the status of custodial citizenship among all of the community members. Study participants 
consistently reported feeling unheard by local government representatives and felt largely powerless to exercise voice in decision-making processes. Even in the context of open government meetings, such as those held as part of Vison Russell, residents felt their political perspectives did not matter and went unheeded. They could not control the access to amenities and the quality of government services in their neighborhood, nor whether or not they would be able to stay in the future. And as a result, the poor felt they encountered a largely anti-democratic local government, dismissive of their needs.

All of these are reasons why space is a key consideration in this study. Adding space to an analysis of custodial citizenship is how I build on the important work of Lerman and Weaver (2014). To use Sotomayor's words, residents felt like subjects of the carceral state because of where they lived and the confluence of local government interventions in their community. The unequal economic standing of residents living in concentrated poverty shaped substantive citizenship experiences making all who live within the borders of the community "custodial citizens."

As Sampson (2012) argued, a durable, spatial logic mediates much of our daily social lives and creates an enduring effect allowing concentrated neighborhood disadvantage and inequality to persist over time. The interviews lead me to understand part of this durable spatial logic is created through government institutions, the carceral state being the most obvious and the subject of this study. For example, the historical housing policies that contributed to hypersegregated urban neighborhoods are another example of how a durable spatial logic is created and maintained through government interventions. 
Carceral state contact exacerbates poverty and profoundly distorts social relations in families and communities, particularly when concentrated in space. The carceral state functions through a systematic policy of disenfranchisement targeting specific communities and spaces marked by poverty and also race, allowing inequality to persist overtime. The near-predictable leveling of criminal justice resources toward these neighborhoods perpetuates structurally unequal outcomes and can be understood as part of a neoliberal urban governance approach.

\section{Surveillance and Punishment in Interlocking Government Institutions}

When the term "carceral state" is invoked, it is most commonly thought of as the series of state institutions that constitute the criminal justice system and its processing of people from arrest to incarceration. The research I conducted for this research project, however, led me to think of the carceral state much more broadly. In the introduction, I defined the carceral state as the state's exercise of its punishment and surveillance powers in a variety of forms. The hyperpunitive approach to poverty that is a hallmark of neoliberalism is present in more than just the criminal justice system.

The interviews revealed a series of interlocking government institutions that also used punishment and surveillance mechanisms to govern the citizenry. The Louisville Metro Housing Department and the Cabinet for Health and Family Services stood as two local institutions that governed through such policies. For example, public housing residents reported their ability to procure work and report a growth in income could lead to a significant diminishing of their available government benefits and an increase in their rent. Residents described home checks for which, they could be fined if the home was not 
considered clean. One interviewee explained, "Just to go get assistance is hard. I feel like I got to tell them the last time I took a shower. It's hard. Trying to find a nice, decent job is hard. And when you do, they ain't paying much, your food stamps get snatched. Your rent goes up sky high. You're barely providing for your babies as it is, and you're worried about how they going to eat all month.”

Attentiveness to the interlocking government institutions are important for two reasons. First, the implications of these interlocking institutions for residents bring to mind Marilyn Frye's birdcage analogy to describe oppression, where ones' options are "pressed" (2016). The analogy follows that the bird remains in the cage not because of one wire but, because a series of wires combine to contain it. These interlocking institutions, including the carceral state, create a host of barriers that residents encounter, complicating their daily lives in the city. Once again, I view a series of government interventions as a structuring force that creates a durable spatial logic in neighborhoods that maintains inequality over time as described by Sampson (2012). The carceral state and the government's exercise of surveillance and punishment through other mechanisms reaches into homes and tears families asunder.

The interviews reflected the following words from Loic Wacquant, "the panoptic and punitive logic proper to the penal field tends to contaminate and then to redefine the objectives and mechanism of delivery of public aid." Among residents of Portland and Russell, their experiences with social services were one that identified a scaling back of available support and a series of punishment and surveillance mechanisms that governed the distribution of aid. Due to the series of interlocking institutions, particularly those providing social aid, custodial citizenship is generated by a sequence of local government 
actions that surveil and punish residents.

The containing, segregating function of the carceral state operates comprehensively at the neighborhood level and is arguably the most influential, element in a series of government institutions shaping urban life for the poor. The ubiquity with which residents identified police as the most prominent institution in local government supports this contention. The interviews revealed that policing for the poor is the most visible and prominent government policy approach to the neighborhoods. These citizenship experiences in the city among the residents of two West Louisville neighborhoods were steeped in economic inequality and crossed racial lines, and I find that there is community-wide custodial citizenship occurring in these spaces.

\section{The New Citizen in the Neoliberal City}

The interviews revealed neoliberalism in local government institutions and the ways citizenship comes to be redefined through a neoliberal framework that emphasizes individual responsibility. First, I discuss the way broken windows policing practices criminalize poverty and reflect the penal aspect of neoliberalism, what Harcourt calls "neoliberal penality." I then attempt to connect the individual responsibility ideas embedded in neoliberalism to colorblind racism to highlight the interrelationship between race and class. Afterwards, I identify how the citizen is defined as a revenue generator in the neoliberal city, and the ways this is manifested in the carceral state. Finally, I argue there are two strands of neoliberal urban governance- one for the rich and one for the poor. One dimension of neoliberalism emphasizes deregulation to facilitate free market 
growth and encourage investment, while the other calls for persistent state interventions that impose harsh punishment and surveillance of the poor. These persistent state interventions ultimately redefine citizenship in the study and create custodial citizenship at the neighborhood level.

\section{Neoliberal Penality}

Positioning the expansion of carceral state deployment in neoliberalism may initially seem contradictory but as Weaver (2016) explains, "For neoliberals, there is no contradiction in state intervention per se. Rather the key is the behavior of the state. Here the goal is not the destruction of the state but rather its reorientation. To the extent that the state intervenes to promote markets, privilege capital, and resist claims on private property, it is a most welcome weapon in the neoliberal armory" (p. 13).

The arrest data and the interviews revealed broken windows and order maintenance policing practices that target low-level offenses and criminalize populations in areas tagged as "disorderly." One primary example from the quantitative data was the high number of criminal trespass and loitering arrests in Beecher Terrace, also supported by the interview data of residents who felt their very presence in the community was enough to generate police attention. Many of the interviewees reported being stopped while walking through their community, some said officers began questioning them in relationship to other criminal activity occurring in the neighborhood, and many Beecher residents talked about being unable to sit on their porch without intervention from the police. Even white women in Portland talked about being stopped and questioned at random while walking in their community. These experiences illustrate practices of order 
maintenance and broken windows policing from the perspective of those who most directly experience it. Also, recall from Chapter 1 the interrelationship between neoliberalism and this form of policing propagated by neoliberal think tanks, such as the Manhattan Institute.

I ground the policing practices described by residents in "neoliberal penality." As explained in chapter 1, Harcourt's concept of neoliberal penality views government interventions, heightened punishments, and increased surveillance as logical state action to calibrate the behavior of individuals deemed as unacceptable in the free market. Because the residents live in neighborhoods that visibly communicate "disorder," their communities come to be hyperpoliced. Returning to a quote in chapter 2 , under a neoliberal framework, "Government policy turns from the concept of collective wellbeing and community-building to the problems of particular 'communities' that require regulation, surveillance and discipline" (Brodie, p. 123).

In Beecher, the race of predominately black residents living in the housing project contributed to the idea of the space as disorderly and requiring state intervention to regulate resident behavior. The individual responsibility ideology of neoliberalism has racial implications, precisely because the social order is highly dictated by racial ideology. Perry is instructive here when she writes, "accountability talk in American popular culture has become racialized.... The discursive demand for black accountability and responsibility implies that the average White citizen is accountable for his or her behavior, while the average Black person is not (124)." It is easier to position black people living in hypersegregated poverty as responsible for their own living conditions 
when the history of government policies leading to its creation is replaced by racial ideology; this is an example of how racial ideology intersects with neoliberal ideology.

Further, while the structure of the political economy has changed, racially disparate, hierarchical outcomes persist through institutional interventions, but are understood as the individual failings of people who inhabit impoverished spaces. Race and class are inseparable in American society, political institutions are raced, economic outcomes are raced, and the ideologies that dominate the political economy are raced. In the current configurations of race and class, we are able to tie colorblind racism to neoliberalism, and view their symbiotic relationship.

\section{Citizens as Revenue Generators}

In the neoliberal political economy, I identify two ways citizenship is predicated on being a revenue generator. First, the roll back of the social welfare state views public goods like education, healthcare, and food as primarily accessible through the market. A network of contracted government entities is more like to provide patchwork social services to those in need as opposed to direct assistance from government agencies. Also, there exists a trend of city governments funding their operations through criminal justice fines and fees, as highlighted by the Ferguson DOJ report. Residents in my own research project discussed how fines and fees, especially for low-level offenses like criminal trespass, impacted their lives.

The neoliberal pursuit of lean government and austerity measures has created a need to generate revenues through alternative means and the carceral state has 
increasingly begun to fulfill this role. Imposing higher taxes to generate revenues goes against the tenets of neoliberalism, while imposing financial penalties on those who fail to behave responsibly in the free market, i.e., neoliberal penality, is perfectly acceptable. These are examples that highlight what Guarneros-Meza and Geddes (2010) call the "market democracy" or "market citizenship" associated with neoliberalism.

The interviews also revealed citizens in the city as revenue generators, and as such their experiences with local government are shaped by their class status, particularly in their neighborhood of residence. The interviews revealed a populace that desired education, healthcare, clean parks and public spaces, and access to healthy food but, in the neoliberal framework of governance, these services are accessed through participation in the free market. To acquire these goods becomes incredibly difficult for those who live on $\$ 10,000$ a year or less.

In interviews community members viewed the ineffectiveness of and differential treatment by local government as resulting from their class status. Simply put, the government failed to fix the problems in their community by investing dollars because they were poor. To return to a quote from Chapter 1, "urban areas are currently dominated by forms of governance... in which market principles infuse not only economic relations but also social and political relations. They form a dynamic infrastructure of urban governance that leaves some legal residents... effectively outside of the de facto polity through which urban space is produced."

Fines and fees assessments, political neglect resulting from a lower-economic class status, and the revitalization processes happening in both communities lead me to argue that neoliberalism has reshaped the definition of citizenship. The state's role is only 
minimally conceived of as a provider of social welfare benefits, these must be acquired through the free market by exercising one's own individual responsibility. Under a neoliberal view of citizenship, residents fund the operations of government towards the ends of economic development but, not social welfare.

In line with the notion that the city government focus is to maximize revenues, city policing can be connected to efforts to make the communities more desirable for investment as well. To clear away "undesirables" and target signs of disorder are the impetus behind broken windows policing tactics. Writing about the needs of capital in the era of neoliberalism, Rachel Weber (2002) wrote that municipalities justify state intervention by stigmatizing properties targeted for demolition and redevelopment. Both the Portland and Russell neighborhoods have been identified as sites for urban revitalization by both private developers and local government. According to Weber, "states discursively constitute, code, and order the meaning of place through policies and practices that are often advantageous to capital" (p. 524). Therefore, I position the state interventions occurring via the carceral state to be grounded in neoliberal forms of local governance, and this in turn influences the content and meaning of citizenship.

Hackworth (2007) squarely positioned HOPE VI within a framework of neoliberal urban governance. The progeny of this program, Choice Neighborhoods, is the government grant through which Louisville is funding its revitalization of Beecher Terrace. Hackworth writes:

"Hope VI represents much more than basic divestment of the housing stock. It also represents a more transparent roll-out of neoliberal policy in practice. It has been linked- via the 1998 Quality Housing and Work Reform Act- to the "work responsibility" acts discussed earlier, and the program's promotional material is rife with the language of economic "self-sufficiency." Increasingly, tenants must behave in "acceptable" ways 
to continue to receive their housing benefits. PHAs (public housing authorities) have been given new powers to evict for behavioral or even economic reasons. In HUD's new "One Strike and You Are Out" program, for example, PHAs are able to evict tenants for criminal activity committed by any member of a household on or off the public housing complex grounds. It is part of a more transparently interventionist set of neoliberal state practices" (p. 71).

The interviews reflected and supported Wacquant's conceptualization of government in the neoliberal era as a centaur state with the dismantling of its social welfare and economic arms while expanding the carceral state. The interviews show that these processes are also occurring at the urban institutional scale. Both Portland and Russell residents identified community based non-profit institutions, such as the Neighborhood House and Dare to Care, not direct government aid, as the most important resources in their community. The outsourcing of social supports reflects the hollowing out of the social welfare state. Rather than relying on food stamp benefits, or other directly administered government supports, social services are received via a network of community-based institutions and non-profits. One interviewee in Portland noted Louisville Metro government funded the program for the elderly at the Neighborhood House where one focus group took place.

Residents in both Russell and Portland felt the impact of rollbacks in social supports and discussed the community wide implications. One white male in Portland explained, “[T]here's people just trying to make a dollar. Look at our presidency. Look at the way everything is going, they're trying to cut out Medicare and everything else. My dad just got his check cut and he's disabled. So people are looking for another way to make money. So if my check gets cut, I'm going to go out and hustle." An African American woman in Russell expressed the same sentiment, that individuals in poverty are placed in incredibly dire and untenable financial situations when social supports are 
diminished. These narratives give us a view of neoliberalism on the ground, and show how real, everyday people are impacted by neoliberal political imperatives.

\section{Race and Racial Ideology}

Race is one of the most deeply contested and controversial concepts in American society. A mere mention of the phrase "race relations" can invoke discomfort. A relatively new phenomenon in the human experience, race developed over the course of hundreds of years. What is agreeable about race is that it is an enigma. How to define race, the ways it functions, how it shapes lives and society, the operation of racism- these are all highly debated questions tied to race and racism. Clearly this dissertation will fall short of articulating definitive answers about race but I only seek to provide alternative ways to think about racism and the racially-disproportionate reach of the carceral state.

In this section I lay out distinct ways the research complicates the racial motivation arguments explaining the explosion of the carceral state primarily as the result of racialized social control and unpack what they mean for our understanding of race. First, I discuss why race in American society cannot be fully articulated in a complete and sensical way without a consideration and attentiveness toward its connection to economic and social class. Any rendering of race that does not also acknowledge class distinctions and the political economy are simply insufficient. I also distinguish race into its ideological and structural dimensions. Ideology and structures unfold as distinct processes that are also in symbiotic relationship with each other. The latter, as I will argue, operates in institutions through not only individual racial biases but, also through the process of "discriminatory design" (Benjamin, 2016). The implications of being more 
nuanced in considering how race operates to create unequal outcomes in society are that solutions to addressing racial inequality requires addressing both aspects of the twoheaded hydra.

Persistent unwanted encounters with police, struggles with accessing enough food, the inability to procure stable work, and nihilist views of local government were all similar views held by both poor white and poor black participants in this study. Sometimes, residents talked about their experiences in the city using the exact same words and phrasing. From these incredibly similar narratives I deduce that both race and class analyses are integral to understanding the carceral state. Attempting to comprehend the carceral state without an acknowledgement of how race is part of the hierarchical political economy leaves an incomplete picture of how our social world is shaped by government institutions and distributions of wealth.

Class, and concentrated poverty in space specifically, has the most profound impact on shaping the tangible substance of the lives of community residents in the neighborhoods of study. It leads them to have similar contact and experiences with the carceral state because they live in hypersegregated spaces that are marked as areas of disorder that require persistent state intervention. Race contributes to the process of creating disproportionate outcomes of wealth inequality and where one lives, but poor people in Portland and poor people in Russell have incredibly similar experiences.

Not only their carceral state experiences, but their built environment impedes access to healthy food and jobs and results from the impoverished status of their community and a lack of capital investment. Black and white interviewees maintained comparable outlooks of local government and described neighborhood life similarly. The articulations 
of disenfranchisement politically, socially, economically, and spatially, discussed in previous chapters, were almost wholly indistinguishable between the two neighborhoods. I grounded those parallels in the class status of individuals living in impoverished neighborhoods and view them as part of the unequal hierarchical structure of the political economy that disenfranchises and creates barriers for all poor people residing at the lowest rungs of it economically.

This is not to say, however, that class is the only element in the carceral state's community-wide reach that generates custodial citizenship. In my analysis, race plays a role in carceral state outcomes on two levels: structurally and ideologically. I take up a summary of structures first. Racially biased, discriminatory practices led to and maintain the disproportionate hypersegregation and isolation of African Americans. The institutional policies that function to maintain class hierarchies disproportionately along lines of race are what I refer to as the structural dimension of race.

American political institutions are raced as is the economy, and by "raced" I mean that racially disparate outcomes are readily observable. I attribute these disparities to discriminatory design, to use the terminology of Ruha Benjamin (2016). The notion of discriminatory design as applied to the carceral state can also help account for the existence of mass incarceration in places where African-Americans wield political and economic power and constitute the majority of the police force. To paraphrase Benjamin's (2016) concept, once the system is primed to produce a particular outcome, racial animus is not necessary for the discrimination to continue. The other important aspect of Benjamin's (2016) idea of discriminatory design is that it considers economic imperatives in the analysis. And here too, is an additional framing of how I think of 
racism in the carceral state. That the function of the carceral state incentivizes incarceration in addition to a narrative of social control for black people.

I view ideology as distinct but also as in relationship with racial structures. Ideologically, race functions to identify and justify these racially disproportionate outcomes created by political institutions and economic shifts as natural and normal. Recall from Chapter 4 the ways Beecher residents tied their carceral state interactions and the harassing nature of the policing in their community to the fact they were black and poor. Even the ways whites in Portland referred to as the "white" ghetto show how racial outcomes are discussed as a natural sorting process.

Thinking through the role of race requires more than a general invocation of racism as the impetus for mass criminalization. There are more complex processes embedded in the political economy that produce these outcomes. Structural racism and racial ideology are mutually supportive; they are in symbiotic relationship with each other but understanding structural racism requires a conceptualization of it as permanently embedded in the political economy.

Race is a malleable social construction with contours that change and transform in response to the political economy. Race has long been a key element of the American carceral state in the ways that has served to manage and control black labor, as described in Chapter 2. While racial animus exists in the carceral state among individual actors, the role of race should also be considered in terms of its structural function and the uniquely American way a racial hierarchy is part and parcel of the political economy.

Racial ideology also plays a role in the carceral state expansion and is connected to the racial animus among individuals with discretionary power in the carceral state 
acting either explicitly or implicitly. Recently, a local news story that reported a police officer, "told a Louisville police recruits it was OK to shoot teenagers caught smoking marijuana if they were black." (Ellis, 2018). The officer served in law enforcement for 30 years and was the chief of the Prospect police department, a wealthy suburb outside of Louisville. To act as if carceral state agents (including black police) are not also subject to the shared, social frameworks for thinking about race would be naïve. In America, race is the most profound form of social ordering and all of us living here abide by what Omi and Winant call, "racial etiquette." They define racial etiquette as interpretive codes, frames, and meanings that operate in daily interactions. Racial ideology creates a frame for people to comprehend and act in the world.

However, these dispersions of race in space and racially disparate outcomes in the carceral state perform another ideological function. It serves to mask what are more elusive class hierarchies in the political economy that also function to disenfranchise whites. Race operates to "hide the gap" of the large economic inequalities that exist among whites in American society. This is precisely the point Ian Haney-Lopez (2015) makes in Dog Whistle Politics- that the focus on race by politicians using colorblind racist imagery allowed for the passage of regressive policies that shrunk the middle class and exacerbated poverty.

When white incarceration is viewed as accidental or haphazard, rather than as the result of the way the state manages poor populations, it misses the political economy functions that are aligned along lines of class. It misses how punitive neoliberal urban governance disenfranchises all poor people; whites are not bystanders, they are victims of economic processes that have created large wealth gaps in American society. Many 
functions of the carceral state that contribute to its rapid growth can be attached to neoliberalism and the political economy as described earlier. For example, the shift toward a cash bail system that has resulted in more detainees remaining incarcerated pretrial impacts people along lines of class. Yet, how much bail is set can be influenced by racial ideology that criminalizes blackness, and black people are more likely to be poor and unable to afford bail because of the raced political economy.

A final note on race and the carceral state derived from this study addresses one of its limitations- its reliance on the black-white binary of American race relations. The criminal justice system's reach into poor, African American communities maintains similarities to the experiences of Latinx communities, especially when one considers the ramping up of the authority of ICE agents and the proliferation of immigrant detention centers.

\section{Women's Experiences}

Although the project began with a focus on race and class, interviewees were primarily women. The prevalence of women's experiences in the court related to their own children and grandchildren, illustrated the disproportionate reach of child protective services into the lives of poor families. In both Russell and Portland, many of the women's experiences with the court system were tied to issues of child custody. One white woman interviewee described her experiences, "I've been going to court over temporary custody of my granddaughter. Its taking forever, I was appointed a lawyer but the court system for kids is overloaded." Another lifetime resident white woman interviewee living in Portland became involved with child protective services when her 
son failed to attend to school. There were multiple other women who either lost custody of their children, some due to carceral state contact, or grandmothers who were responsible for raising their grandchildren due to their own children's inability to do so.

The interviews also revealed how women generate social networks to sustain and support their families within the context of poverty. Two Black women, one from Portland and one from Russell, were both adamant about sharing helpful information about resources with their neighbors. Multiple Black women in Beecher Terrace talked about sharing food with their neighbors, and how they "looked out" for their friends in the community by checking on them and their homes. This is an important point that is often neglected in research on concentrated poverty that addresses how women create social supports amongst each other for survival.

In future research, I hope to use this qualitative data, particularly because the majority of the interviewees identified as women, to think through more systematically about the role of gender. Wacquant (2009) discusses punitive welfare policy as the gendered "flip side" to carceral state interventions primarily impacting men. I'm not entirely sure this is an accurate conceptualization (the fastest growing prison population was black women). Many of the women interviewees had their own direct carceral state experiences, and I do believe their status as mothers influenced those outcomes in ways different than that of men.

\section{Concluding Thoughts}


With this research project I have attempted to present an alternative framing for understanding the expanding carceral state and to more fully understand its impact on substantive citizenship in poor urban neighborhoods. Through the process of interviewing over seventy community members I learned that space matters, neoliberalism is happening locally and is transforming urban governance of the poor, and that class matters in addition to race. The framing I present with this work contends that the rapid growth of the carceral state cannot be fully understood solely on racial terms. An attentiveness to the political economy and racism as a hierarchy embedded within it can supplement the ways we currently think of the carceral state.

There is a great need for research that explores intra-racial class differences and digs deeper into how whites and non-black people of color experience the carceral state, particularly among those who live in concentrated poverty. One limitation to this study is that it exists in a black-white binary that is all too familiar in the field of mass criminalization and the carceral state. Future research will hopefully unpack the role of the political economy and race, immigrant communities and rural poor white communities are spaces where I believe strong parallels could be drawn to the findings I present here.

There are two critical points that I pull from the findings of this research. First, that without radical structural and ideological interventions, the system of mass incarceration will transform into another system of hierarchical oppression as it is challenged. The rapid proliferation of technologies that surveil like electronic monitoring and facial recognition programs is occurring as I write this. Second, poor people of all races are disenfranchised, and concentrated poverty exacerbates the citizenship 
experiences of entire communities. Entire neighborhoods come under the watchful eye of state surveillance via police and social welfare agencies.

\section{The Right to the City}

Recently I attended a city council meeting in Atlanta, Georgia related to a newlypassed bail reform ordinance that sought to diminish pretrial incarceration resulting from the inability of inmates to pay for their release. Cash bail has become part of a national conversation focused on the criminalization of poverty that hinges liberty on the ability to pay. While waiting for city council members to arrive, community organizers present for the hearing sat in the seats with microphones and began to ask a series of questions of the attendees. What would you do to help keep our city safe? How would you use the money that is currently used to incarcerate? What would you spend taxpayer dollars on? The audience, primarily community members in support of the bail ordinance and ending mass criminalization, proposed different responses outside of police, law and order, and more arrests as a means to combat crime.

I tell this anecdote because, for me, it indicates precisely what the right to the city could look like, access to levers of political power and the ability to exercise voice in the ways the city looks and is governed. In Chapter 3 of this work, I used Lefebvre's (1967) concept of the right to the city to frame the concept of urban citizenship. Lefebvre (1967) called for a re-imagining of city space that accounted for its social value and the participation of urban residents in the political institutions governing their lives. I find that this theoretical concept also represents a starting point for resolving the current 
carceral state implosion and to push back against current manifestations of neoliberalism and racism that generate unequal outcomes along lines of race and class.

Lefebvre's (1967) conceptualization of city space and the rights of those who inhabit it stands in opposition to neoliberal forms of government that limit voice and exclude poor residents from decision-making processes. Police unions in cities across the country fight against any citizen oversight into their practices through mechanisms like civilian review boards, and police officers who shoot and kill citizens remain relatively insulated from criminal prosecution and its consequences. A right to the city approach says that the residents of poor communities deserve to have a say in the political and economic processes that control the destiny of their community.

Socially, residents in impoverished communities merit respect as full and equal citizens of the city, with equal access to public space and amenities. For me, a right to the city rejects the hierarchy of the political economy that allows wealth to be concentrated in the hands of a few and favors a democratic ownership of modes of production. The people who are currently living in a residential space should have more control over the government funded private-public partnerships that reshape their neighborhoods with the potential to ultimately displace them. Perfunctory meetings about a revitalization plan that has already been set into motion does little to incorporate the voices of residents in decision-making power. One woman who attended a Vision Russell meeting said that someone from city government came and showed them a map of crime in the community, and her response was, "why are you showing us this, we live here, we know."

Instead of the right to the city what we have currently is a political framework that punishes the poor through a variety of devices, including the hyperpolicing of spaces of 
perceived disorder. This hyperpolicing in order to abate crime is targeted more towards making the space desirable for investment than it is about public safety for the residents currently living there. Residents in the neighborhoods of study are made to feel suspicious and unwelcome in their own neighborhoods and in other more affluent communities in the city.

What does policing look like when community members control it? I doubt dangerous high-speed chases through the neighborhood and stop-and-frisk practices that diminish community trust would top the list of public safety initiatives. The vast majority of the interviews included in this study highlight the need to incorporate resident voices and perspectives in the institutions that govern their community and the larger city. The status quo is one where community members feel ignored and dehumanized. The interviews revealed a populace that felt incredibly disenchanted with local government officials and institutions such as the police.

More radical democracy is required to help dismantle the structures that perpetuate racial isolation and economic segregation. Greater inclusion into political and economic processes are shunted by a neoliberal city government that addresses poverty through primarily punitive and surveillance mechanisms. Structural racism requires a radical reformation and rethinking of democracy and its institutions in order to combat the discrimination by design that persists over time. Individual residents should be able to sit in seats of power like the community organizers I described and alter the format of the conversation around urban governance in a way that solicits, not rejects input from residents. 
An ideological reframing of socio-cultural relationships needs to happen in American society as well. Individuals living in the neighborhoods of the study feel devalued, disenfranchised, and unequal to their wealthier counterparts. The question of social citizenship, who is worthy and valuable in society, requires communities to grapple with racial ideology. It also requires pushing back against the dominant neoliberal framing of community as collective economic development and policies that surveil and punish poor people as a means of developing individual responsibility.

In the early chapters of this work I identified mass criminalization as the result of dramatic changes in the political economy, the ways it changed the racial structure of the U.S. while staying true to the racially discriminatory economic imperatives of the carceral state. What comes next if the fundamental hierarchies of race and class remain undisturbed when another series of political and economic changes arise? The technological advances of artificial intelligence, facial recognition, and GPS monitoring are already being sold by private companies to local police departments and corrections agencies. Are we entering into an era of mass surveillance where city residents are consistently monitored through the use of technology deployed by the carceral state? If so, what will it mean for the future of democracy and citizenship rights in the city?

If we continue down this same path, the answers point to more of the same. The right to the city rejects the idea that local state institutions like the carceral state should be allowed to incentivize the subjugation and incarceration of poor residents in order to create profits for a few. Capital must be democratized, political processes must be democratized, and community meetings must involve real, tangible decision-making power for the people from impacted neighborhoods who are present. Then, we may see a 
different series of policy priorities emerge, priorities that value people and community above the free market.

It is entirely possible that a call for the right to the city is too ethereal and ephemeral to generate tangible solutions to the mass criminalization enigma. How can community engagement and radical democracy help address the difficult ideologies of race that people hold serving to normalize inequality? I would hope that it could function to humanize people through allowing them to engage in political and economic processes that impact their lives. This may be a bit too hopeful but, the status quo for the community members I interviewed is full of too much hopelessness. In order to transform the hierarchy and to make citizens equal, there must be a transformation of the way wealth is distributed and political decisions are made. The starting point must be that all residents have a right to the city. Only then can we begin to address the widespread mass criminalization of the poor. 


\section{REFERENCES}

Alexander, M. (2010). The New Jim Crow: Mass Incarceration in the Age of Colorblindness. New York: The New Press

Allard, P. (2012). When the cost is too great: the emotional and psychological impact on children of incarcerating their parents for drug offences. Family Court Review, 50(1), 4858

Alloway, T. and Katz, L. (2016, November 9). Private prison stocks are surging after Trump's win. Retrieved from https://www.bloomberg.com/news/articles/2016-1109/private-prison-stocks-are-surging-after-trump-s-win

Bailey, P. (2018, April 13). Gang bill critics say targets black men and children passes Kentucky legislature. Courier-Journal Retrieved from https://www.courierjournal.com/story/news/politics/ky-legislature/2018/04/13/kentucky-senate-moves-gangbill-forward-rejects-racial-impact-study/515293002/

Baye, B. (1989) A place in time: the story of Louisville's neighborhoods Russell.” Courier-Journal. Retrieved from https://louisville.edu/cepm/westlou/west-louisvillegeneral/a-place-in-time-courier-journals-history-of-neighborhoods/

Bell, D. (1991). Reconstruction's racial realities. Rutgers Law Journal 23, 261

Bell, D. (1992). Faces at the bottom of the well: the permanence of racism. New York: Basic Books.

Benjamin, R. (2016). Catching our breath: critical race STS and the carceral imagination. Engaging Science, Technology, and Society 2, 145-156

Blackmon, D. (2009). Slavery by another name: The re-enslavement of black Americans from the Civil War to World War II. Anchor. 
Bliss, L. (2015, July 2015). Mapping Chicago's 'million dollar blocks.' Retrieved from https://www.citylab.com/design/2015/07/mapping-chicagos-million-dollarblocks/399557/

Bonilla-Silva, E., Lewis, A. \& Embrick, D. (2004). "I did not get that job because of a black man.": the story lines and testimonies of color-blind racism" Sociological Forum 19(4), 555-581

- Bonilla-Silva, E. (2014). Racism without racists color-blind racism and the persistence of racial inequality in America, $4^{\text {th }}$ ed. Lanham: Rowman \& Littlefield Publishers, Inc.

Body-Gendrot, S. (2011). The social control of cities?: a comparative perspective. John Wiley \& Sons

Bowling, C. (2015, July 3). Can West Louisville pull off a resurgence. Louisville Business First, Retrieved from https://www.bizjournals.com/louisville/printedition/2015/07/03/can-west-louisville-pull-off-a-resurgence.html

Bowling, C. (2016, July 1). Louisville awarded \$1 million in Choice Neighborhoods Grant funding. Insider Louisville, Retrieved from https://insiderlouisville.com/metro/louisville-awarded-1-million-in-choiceneighborhoods-grant-funding/

Brenner, N. \& N. Theodore. (2002). Cities and the geographies of 'actually existing neoliberalism.' Antipode 34(3), 349-379

Brodie, J. (2000). Imagining democratic urban citizenship In E. Isin ed., Democracy, citizenship, and the global city (pp. 110-128) London: Routledge

Brunson, R. \& Weitzer, R. (2009). Police relations with black and white youths in different urban neighborhoods. Urban Affairs Review 44(6), 858-885

Buck, P. (2017). The strange birth and continuing life of the US as a slaving republic: race, unfree labor, and the state. Anthropological Theory 17(2), 159-191

Burch, Traci. (2013). Trading democracy for justice: criminal convictions and the decline of neighborhood political participation. Chicago: University of Chicago Press

Butler, P. (2017). Chokehold: policing black men. New York: The New Press

Carr, P., Napolitano, L., \& Keating, J. (2007). We never call the cops and here is why: a qualitative examination of legal cynicism in three Philadelphia neighborhoods.

Criminology 45(2), 445-479 
Cashin, Sheryll (2004). The failures of integration: how race and class are undermining the American Dream. New York, NY: Public Affairs

Cashin, Sheryll (2014). Place not race: a new vision of opportunity in America. Boston, MA: Beacon Press

Chang, C. (2017, October 14). Louisiana is the world's prison capital. The Times Picayune Retrieved from http://www.nola.com/crime/index.ssf/2012/05/louisiana_is_the_worlds_prison.html

Chin, J. (2012). The new civil death: rethinking punishment in the era of mass Conviction. University of Pennsylvania Law Review 160, 1789-1833

Clear, T. (2007). Imprisoning communities: how mass incarceration makes disadvantaged neighborhoods worse. Oxford: Oxford University Press

Coaston, J. (2017, July 3). "Jaywalking while black". New York Times Retrieved from https://www.nytimes.com/2017/07/03/opinion/jaywalking-while-black-jacksonvilleflorida.html

Coates, T. (2015). Between the world and me. New York: Spiegel \& Grau

Cole, D. (1999). No equal justice: race and class in the American criminal justice system. New York: The New Press

Davis, A. (2017). Policing the Black man: arrest, prosecution, and imprisonment. New York: Vintage Books

Denton, N. \& Massey, D. (1993). American apartheid: segregation and the making of the underclass. Cambridge: Harvard University Press

DeFina, R. and Hannon, L. (2010). The impact of adult incarceration on child poverty: the impact of adult incarceration on child poverty: a county-level analysis, 1995-2007. The Prison Journal 90(4), 377-396.

Dickerson, K. (2015, April 27). Sully's $4^{\text {th }}$ Street Live facing racial discrimination, classaction lawsuit. WHAS11 Retrieved from https://www.whas11.com/article/news/local/sullys-4th-street-live-facing-racialdiscrimination-class-action-lawsuit/172530451

Downs, J. (2014, February 13). Nearly half of Louisville lives in "extreme segregation". Courier-Journal Retrieved from https://www.courierjournal.com/story/news/local/2014/02/12/nearly-half-of-louisville-lives-in-extremesegregation/5436439/ 
Dreier, P.; Mollenkopf, J.; Swanstrom, T. (2004) Place matters: metropolitcs for the twenty-first century, second edition Lawrence, KS: University Press of Kansas

Du Bois, W.E.B. (1998). Black Reconstruction in America. New York: The Free Press

Economic Innovation Group. (2016). Distressed communities index: an analysis of community well-being across the United States. Retrieved from http://eig.org/wpcontent/uploads/2016/02/2016-Distressed-Communities-Index-Report.pdf

Ellis, R. (2018, January 22). "Former Kentucky police official allegedly sent racist messages to recruit. CNN New. Retrieved from:

https://www.cnn.com/2018/01/22/us/kentucky-officer-urged-recruit-to-shootblacks/index.html

Foreman, Jr. J. (2017). Locking up our own: crime and punishment in Black America. New York: Farrar, Straus and Giroux

Fortner, M. J. (2015). Black silent majority the Rockefeller Drug Laws and the politics of punishment. Cambridge: Harvard University Press

Fouborg, E. (2002). Understanding space, understanding citizenship. Journal of Geography 101, 81-85

Frankenberg, R. (1993). White women, race matters: the social construction of whiteness. Minneapolis: University of Minnesota Press

Giulianni, R. (2012, Spring). What New York owes James Q. Wilson. City Journal Retrieved from https://www.city-journal.org/html/what-new-york-owes-james-q-wilson13465.html

Glenn, E. N. (2011) Constructing citizenship: exclusion, subordination, and resistance. American Sociological Review 76(1), 1-24

Gopnik, A. (2012, January 20) The Caging of America. The New Yorker Retrieved from: https://www.newyorker.com/magazine/2012/01/30/the-caging-of-america

Gottschalk, M. (2015). Caught: the prison state and the lockdown of American politics. Princeton: Princeton University Press

Greater Louisville Project. (2015). Louisville: a focus on poverty. Retrieved from: http://greaterlouisvilleproject.org/reports/2015-competitive-city-update/

Guarnizo, L. (2012). The fluid, multi-scalar, and contradictory construction of citizenship. In M. Smith and M. McQuarrie (Eds.), Remaking urban citizenship (pp. 1138) New York: Routledge 
Guzman, D. (2018, May 10). Video shows woman calling police over barbecue at Lake Merritt. SFGate Retrieved from https://www.sfgate.com/bayarea/article/Oaklandbarbecue-Lake-Merritt-Sunday-confrontation-12902520.php.

Hackworth, J. (2007). The Neoliberal City: Governance, Ideology, and Development in American Urbanism. Ithaca: Cornell University Press

Haney-Lopez. I. (2015). Dog whistle politics: how coded racial appeals have reinvented racism and wrecked the middle class. New York: Oxford University Press

Hanna, J., Sgueglia, K., and Simon, D. (2018, May 3). The men arrested at Starbucks are paying it forward big time. $C N N$ Retrieved from

https://www.cnn.com/2018/05/03/us/starbucks-arrest-agreements/index.html

Harcourt, B. (2010). Neoliberal penality: a brief genealogy. Theoretical Criminology $14(1), 74-92$

Hartigan, J. (1999). Racial Situations: Class Predicaments of Whiteness in Detroit. Princeton: Princeton University Press

Harvey, D. (2005). A Brief History of Neoliberalism. Oxford: Oxford University Press

- Harvey, D. (2012). Rebel Cities: From the Right to the City to the Urban Revolution. London: Verso

Herbert, S. \& Brown, E. (2006). Conceptions of Space and Crime in the Punitive Neoliberal City," Antipode 38(4), 755-777

Heath, B. (2014, November 18). Racial gap in U.S. arrest rates: 'Staggering disparity'. USA Today Retrieved from https://www.usatoday.com/story/news/nation/2014/11/18/ferguson-black-arrestrates/19043207/

Herron, Shawn. (1989). "A place in time: the story of Louisville's neighborhoods Portland." Courier-Journal Retrieved from https://louisville.edu/cepm/westlou/westlouisville-general/a-place-in-time-courier-journals-history-of-neighborhoods/

Higginbotham, L. (1996). Shades of freedom: racial politics and presumptions of the American legal process. Oxford: Oxford University Press

About Portland [Web log post]. (2018). Retrieved from Historical Portland http://www.portlandlouisville.com/

Ishwata, E. (2011). We are seeing people we didn't know exist Katrina and the neoliberal erasure of race. In C. Johnson (ed.) The neoliberal deluge Hurricane Katrina, late 
capitalism, and the remaking of New Orleans Minneapolis: University of Minnesota Press 32-59

James, C.L.R. (2012). A history of Pan-African revolt. Oakland: PM Press.

Jargowsky, P. (2015). Concentration of poverty in the new milliennium. Century Foundation and Rutgers Center for Urban Research Education Retrieved from https://tcf.org/assets/downloads/Concentration_of_Poverty_in_the_New_Millennium.pdf

Jones, M. (2015, May 20). Race, space and economics in the West End: The future of Beecher Terrace? Leo Weekly Retrieved from https://www.leoweekly.com/2015/05/thefuture-of-beecher-terrace-race-space-and-gentrification-in-the-west-end/

Justice Policy Institute. (2000). The punishing decade: prison and jail estimates at the millennium. Retrieved from http://www.justicepolicy.org/images/upload/0005_rep_punishingdecade_ac.pdf

Keller, J. \& Pearce, A. (2016, September 2). New geography of prisons. The New York Times Retrieved from https://www.nytimes.com/2016/09/02/upshot/new-geography-ofprisons.html

Kent, A. \& Frohlich, T. (2015, August 27). The 9 most segregated cities in America. Huffington Post Retrieved from: https://www.huffingtonpost.com/entry/the-9-mostsegregated-cities-in-america_us_55df53e9e4b0e7117ba92d7f

King, G. (2012). Devil in the grove: Thurgood Marshall, the Groveland boys, and the dawn of a New America. New York: Harper

Kuymulu, M. (2013). The Vortex of Rights: The Right to the City at a Crossroads. International Journal of Urban and Regional Research, 37(3), 923-940

Lane, (2017, August 30). New jail, same debate: Report argues more beds needed for New Orleans' inmates. NOLA.com Retrieved from https://www.nola.com/crime/index.ssf/2017/08/new_jail_same_debate_report_ar.html

Lawrence, C. (1987). The Id, the Ego, and Equal Protection: Reckoning with Unconscious Racism. Stanford Law Review 39(2), 317-388.

LeBaron, Genevieve \& Roberts, Adrienne. (2010). Toward a Feminist Political Economy of Capitalism and Carcerality. Signs 36(1) 19-44.

Lefebvre, H. (1967). Le droit a la ville. L'homme et la societe 6 pp. 29-35

Lerman, A. \& Weaver, V. (2014). Arresting Citizenship: The Democratic Consequences of American Crime Control Chicago: University of Chicago Press. 
Lopez, A. \& Ryan, J. (2016). Inside Louisville's decades-long problem with housing segregation. WFPL Retrieved from http://wfpl.org/a-look-at-a-decades-old-segregationproblem-in-louisville/

Mahoney, M. (1994). Segregation whiteness and transformation. Univ. of Pennsylvania Law Review 143 1659-1684

Marshall, T.H. (1950). Citizenship and social class Cambridge: Cambridge University Press

Matsuda, Mari. 1987. Looking to the bottom: Critical legal studies and reparations. Harvard Civil Rights - Civil Liberties Law Review 22, 323-383

Mauer, M. (2011). Addressing the Political Environment Shaping Mass Incarceration. Criminology \& Public Policy 10(3), 699-705

McAdam, S. (2012, October 11). New study shows financial impact of Fourth Street Live. Louisville Magazine Retrieved from_https://www.louisville.com/content/new-studyshows-financial-impact-fourth-street-live-attractions

Mele, C. (2013). Neoliberalism, Race, and the Redefining of Urban Development. International Journal of Urban and Regional Research, 37(2), 598-617

Mitchell, D. (2003). The Right to the city: Social justice and the right to public space. New York: The Guilford Press

Mock, B. (2017, February 21). Louisville confronts its redlining past and present. CityLab Retrieved from https://www.citylab.com/equity/2017/02/louisville-confronts-itsredlining-past-and-present/517125/

Muhammad, K. G. (2011). The condemnation of Blackness: Race, crime, and the making of modern urban America. Cambridge: Harvard University Press

Novelly, T. (2017, December 11). Louisville police searched black drivers more often than white drivers in 2016. Courier-Journal Retrieved from https://www.courierjournal.com/story/news/local/2017/12/11/louisville-police-searched-black-drivers-moreoften-white-study/939673001/

Omi, M and Winant, H. (2015). Racial formation in the United States, $3^{\text {rd }}$ edition. New York: Routledge

Ong, P. \& Rickles, J. (2004). The continued nexus between school and residential segregation. Berkeley Journal of African-American Law \& Policy 6(2) 178-193

Pager, D. (2007). Marked: Race, crime, and finding work in an era of mass incarceration. Chicago: University of Chicago Press 
Painter, J. \& Philo, C. (1995). Spaces of citizenship: an introduction. Political Geography 14(2), 107-120

Peck, J. (2010). Constructions of Neoliberal Reason. Oxford: Oxford University Press

Peck, J. \& Tickell, A. (2002). Neoliberalizing Space. Antipode. 34(3), 380-404

Pendall, R. \& Hedman, C. (2015, June). Worlds apart: Inequality between America's most and least affluent neighborhoods. Urban Institute Research Report Retrieved from https://www.urban.org/research/publication/worlds-apart-inequality-between-americasmost-and-least-affluent-neighborhoods/view/full_report

Perry, I. (2011). More beautiful and more terrible: The embrace and transcendence of racial inequality in the United States. New York: NYU Press.

Poe, J. (2017, December 14). Redlining Louisville: The history of race, class, and real estate. Interactive story map Retrieved from https://www.lojic.org/redlining-louisvillenews

Purcell, M. (2012). Insistent democracy: neoliberal governance and popular movements in Seattle. In Michael Peter Smith and Michael McQuarrie, eds. Remaking Urban Citizenship: Organizations, Institutions, and the Right to the City New Brunswick, NJ: Transaction Publishers pp. 173-190

Reed, Jr., A. (2013). Marx, Race, and Neoliberalism. New Labour Forum 22(1), $49-57$

Rose, N. (2000) “Governing cities, governing citizens.” In E. F. Isin, ed. Democracy, Citizenship and the Global City. London: Routledge

Rothstein, R. (2017). The color of law: A forgotten history of how our government segregated America. New York: Liveright Publishing Corporation

Samara, T. (2012). Citizens in Search of a City: Towards a New Infrastructure of Political Belonging. In Michael Peter Smith \& Michael McQuarrie (Eds.), Remaking Urban Citizenship: Organizations, Institutions, and the Right to the City. New Brunswick, NJ: Transaction Publishers. pp. 39-56

Sampson, R. (2012). Great American city: Chicago and the enduring neighborhood effect. Chicago: University of Chicago Press

Sampson, R. and Loeffler, C. (2010) Punishment's place: The local concentration of mass incarceration. Daedalus 139, 20-31

Savitch, H.V.; DuPont, K.; Drumm, E. (2000). The transformation of American cities. In Oscar Gabriel, Vincent Hoffman, and H.V. Savitch (eds.). Urban democracy. Reihe: 
Stadte and Regionen in Europa: VS Verlag fur Socialwissenschaften, Weisbaden. pp. 369-394

Serchuk, D. (2015, November 20). How affluent is your neighborhood?. Louisville Business First Retrieved from https://www.bizjournals.com/louisville/printedition/2015/11/20/how-affluent-is-your-neighborhood.html

Shklar, J. (1991). American Citizenship: The Quest for Inclusion. Cambridge: Harvard University Press.

Shorey, E. (2018, June 21). Black girl tackled by cop at Texas pool party gets settlement from department and city. Oxygen Retrieved from https://www.oxygen.com/crimetime/eric-casebolt-Dajerria-Becton-McKinney-texas-pool-party-cop-settlement

Spalding, A. (2016, September 8). Criminal justice reform and racial disparities in Kentucky. Kentucky Center for Economic Policy Retrieved from https://kypolicy.org/criminal-justice-reform-and-racial-disparities-in-kentucky-2/

Spence, L. 2015 Knocking the hustle: Against the neoliberal turn in Black politics. Brooklyn: punctum books

Stancill, W. School segregation is not a myth. The Atlantic Retrieved from https://www.theatlantic.com/educatiohn/archive/2018/03/school-segregation-is-not-amyth/555614/

Stevens, W. (1975, September 7). Guard cabled out in Louisville riot. New York Times Retrieved from https://www.nytimes.com/1975/09/07/archives/guard-called-out-inlouisville-riot-50-persons-are-injured-and-200.html

Stevens, A. (2014, June 27). Change is coming to Louisville's Portland neighborhood, like it or not. WFPL News Retrieved from http://wfpl.org/change-coming-louisvillesportland-neighborhood-it-or-not/

Stewart, E. (2018, April 15). Starbucks had two black men arrested for doing absolutely nothing. Vox Retrieved from https://www.vox.com/identities/2018/4/14/17238494/whathappened-at-starbucks-black-men-arrested-philadelphia

Tocqueville, A. (1969). Democracy in America. Garden City: Doubleday

Tyler, Tom. (2006). Restorative justice and procedural Justice: Dealing with rule breaking. Journal of Social Issues 62(2), 307-326

United States Department of Justice Civil Rights Division. (2015, March 4). Investigation of the Ferguson Police Department Retrieved from https://www.justice.gov/sites/default/files/opa/pressreleases/ attachments/2015/03/04/ferguson_police_department_report.pdf 
Van Cleve, N.G. (2016). Crook County: Racism and injustice in America's largest criminal court. Redwood City: Stanford University Press

Vega, T. (2016, April 11). The steep cost of driving while black in California. CNN Money Retrieved from http://money.cnn.com/2016/04/11/news/economy/black-driverscalifornia-tickets/

Vera Institute. (2018, May). People in prison 2017 report. Retrieved from https://www.vera.org/publications/people-in-prison-2017

Vision Russell. (2018). Choice neighborhoods grant program. Retrieved from https://visionrussell.org/about/choice-neighborhoods-grant-programs/

Wacquant, L. (1999). Urban marginality in the coming millennium. Urban Studies 36(10), 1639-1647.

-Wacquant, L. (2002). From slavery to mass incarceration: Rethinking the 'race question' in the US. New Left Review 13, 41-60

-Wacquant, L. (2005). Race as civic felony. International Social Science Journal 57(183), 127-142.

-Wacquant, L. (2009). Prisons of poverty. Minneapolis: University of Minnesota Press

-Wacquant, L. (2009). Punishing the poor: The neoliberal government of social insecurity. Durham: Duke University Press

Wakefield, S. and Wildeman, C. (2011) Mass imprisonment and racial disparities in childhood behavioral problems. Criminology \& Public Policy 10(3), 793-817

Weaver, T.P.R. (2016). Blazing the neoliberal trail urban political development in the United States and United Kingdom. Philadelphia: University of Pennsylvania Press

Weber, R. (2002). Extracting value from the city: Neoliberalism and urban redevelopment. In Brenner, N. and Theodore, N. (eds.), Spaces of neoliberalism: Urban restructuring in North America and Western Europe, Oxford: Blackwell

Websdale, N. (2001). Policing the poor from slave plantation to public housing. Boston: Northeastern University Press

Western, Bruce. (2006). Punishment and Inequality in America. New York: Russell Sage Foundation 
Wildeman, C. (2009). Parental imprisonment, the prison boom, and the concentration of childhood disadvantage. Demography 46(2) p. 265-280

Wilson, J. and Kelling, G. (1982, March). Broken windows: The police and neighborhood safety. The Atlantic Retrieved from:

https://www.theatlantic.com/magazine/archive/1982/03/broken-windows/304465/

Wilson, W.J. (2009). More than just Race: Being Black and poor in the inner city. New York, NY: W.W. Norton Company

-Wilson, W.J. (2012). The truly disadvantaged: The inner city, the underclass, and public policy, $2^{\text {nd }}$ ed. Chicago: The University of Chicago Press

Wright, G. (1985). Life behind a veil: Blacks in Louisville, Kentucky, 1865-1930. Baton Rouge: LSU Press

Yin, Robert S. 2014. Case study research: Design and methods, $5^{\text {th }}$ ed. Los Angeles: Sage. 


\section{CURRICULUM VITAE}

NAME: $\quad$ Elizabeth Michele Jones

ADDRESS: Department of Urban and Public Affairs

University of Louisville

426 W. Bloom Street

Louisville, Kentucky 40208

DOB: $\quad$ Louisville, Kentucky - January 15, 1981

EDUCATION

\& TRAINING: $\quad$ B.A., Liberal Studies

University of Louisville

2000-2004

M.A., Pan-African Studies

University of Louisville

2004-2006

J.D.,

Georgetown Law Center

2006-2009

Ph.D., Urban and Public Affairs

University of Louisville

2012-2018

PUBLICATIONS:

2018. Racism, fines and fees and the U.S. carceral state. Race and Class, 59(3), 38-50.

2009. Looking Back to Move Forward: An Intersectional

Perspective on Harris v. McRae. The Georgetown Journal of Law and Modern Critical Race Perspectives 1(2), 379-

NATIONAL MEETING PRESENTATIONS:

The Impact of the Criminal Justice System on Urban Citizenship, National Council for Black Studies 2017 
Mass Incarceration and the Curtailing of Urban Citizenship, Urban Affairs Association Conference 2015

\section{INVITED PRESENTATIONS:}

The Profitability of Racism, Discriminatory Design in the Carceral State, Brandeis School of Law Structural Inequality Symposium 2018

The Civil Rights Struggle in the Era of Colorblindness, University of Kentucky of Law March 6, 2015 